Nevada

Environmental

Restoration

Project

Recommendations and Justifications for Modifications for Use Restrictions Established under the U.S. Department of Energy, National Nuclear Security Administration Nevada Site Office

Federal Facility Agreement and Consent Order

Controlled Copy No.:

Revision No.: 0

February 2008

Approved for public release; further dissemination unlimited.

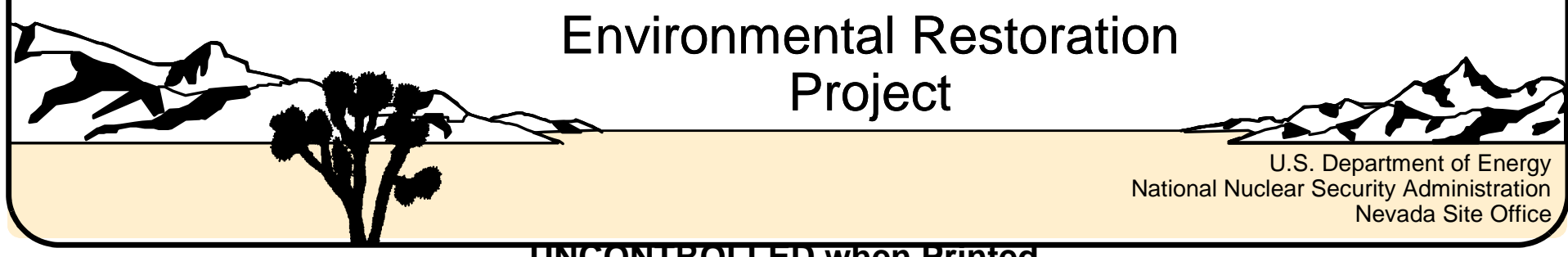


Available for public sale, in paper, from:

U.S. Department of Commerce

National Technical Information Service

5285 Port Royal Road

Springfield, VA 22161

Phone: 800.553 .6847

Fax: 703.605.6900

Email: orders@ntis.gov

Online ordering: http://www.ntis.gov/ordering.htm

Available electronically at http://www.osti.gov/bridge

Available for a processing fee to U.S. Department of Energy and its contractors, in paper, from:

\section{U.S. Department of Energy}

Office of Scientific and Technical Information

P.O. Box 62

Oak Ridge, TN 37831-0062

Phone: 865.576.8401

Fax: 865.576.5728

Email: reports@adonis.osti.gov

Reference herein to any specific commercial product, process, or service by trade name, trademark, manufacturer, or otherwise, does not necessarily constitute or imply its endorsement, recommendation, or favoring by the United States Government or any agency thereof or its contractors or subcontractors. 


\title{
Recommendations and Justifications for Modifications for Use Restrictions Established under the U.S. Department of Energy, National Nuclear Security Administration Nevada Site Office Federal Facility Agreement and Consent Order
}

\author{
U.S. Department of Energy \\ National Nuclear Security Administration \\ Nevada Site Office \\ Las Vegas, Nevada
}

Controlled Copy No.:

Revision No.: 0

February 2008

Approved for public release; further dissemination unlimited. 
Recommendations and Justifications for Modifications for Use Restrictions Established under the U.S. Department of Energy, National Nuclear Security Administration Nevada Site Office Federal Facility Agreement and Consent Order

Approved by: /s/ Kevin J. Cabble

Date: $02 / 05 / 2008$

Kevin J. Cabble

Federal Sub-Project Director

Industrial Sites Sub-Project

Approved by: /s/ John B. Jones

Date: $02 / 04 / 2008$

John B. Jones

Acting Federal Project Director

Environmental Restoration Project 


\section{Table of Contents}

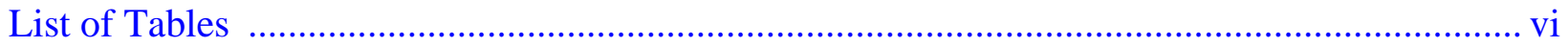

List of Acronyms and Abbreviations ....................................................................................... viii

$1.0 \quad$ Purpose

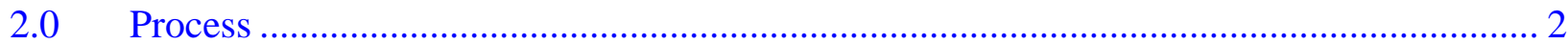

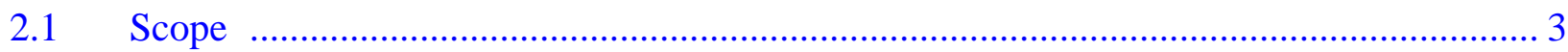

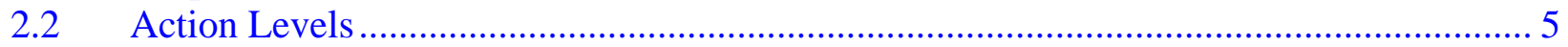

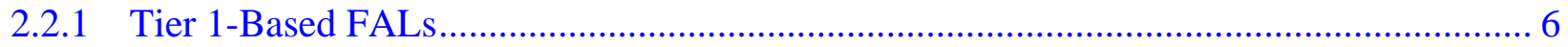

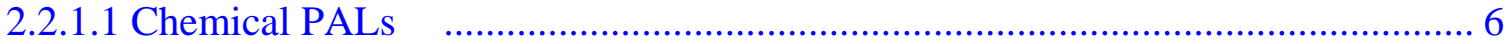

2.2.1.2 Total Petroleum Hydrocarbon PALs .................................................................. 6

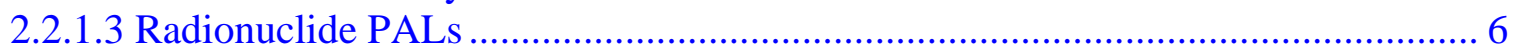

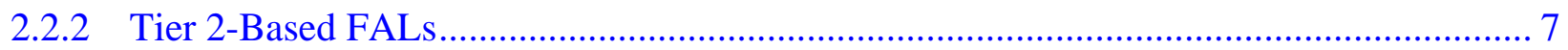

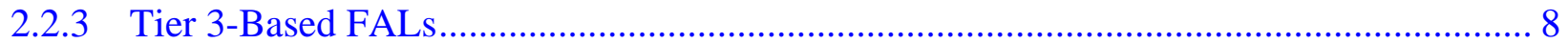

2.2.4 Multiple Constituent Analysis ........................................................................................ 8

2.3 Modified Use Restriction Decision Basis ....................................................................... 9

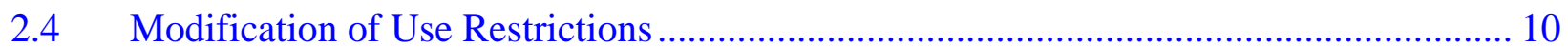

3.0 CAU 34, CAS 03-09-06 - Mud Disposal Crater ................................................................ 11

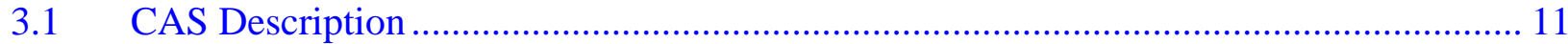

3.2 Current Use Restriction Description.......................................................................... 11

3.3 Basis for Current Use Restriction ............................................................................... 11

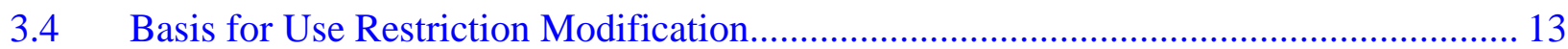

3.5 Proposed Modification..................................................................................................... 13

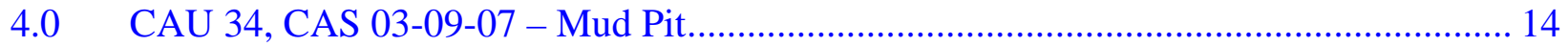

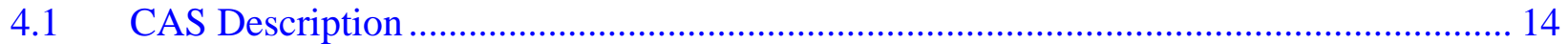

4.2 Current Use Restriction Description................................................................................. 14

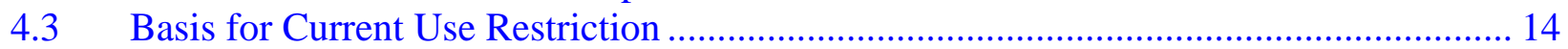

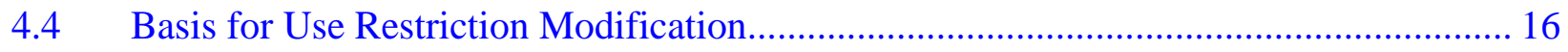

4.5 Proposed Modification............................................................................................. 17

5.0 CAU 214, CAS 25-23-01 - Contaminated Materials, and CAS 25-23-19 Radioactive Material Storage...................................................................................... 18

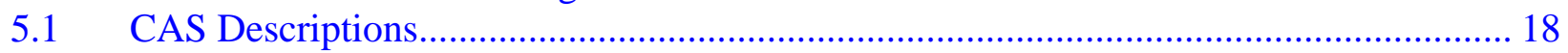

5.2 Current Use Restriction Description........................................................................ 18

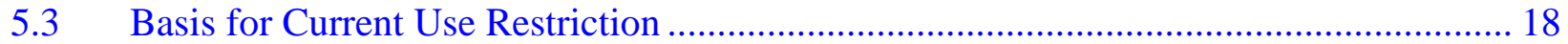

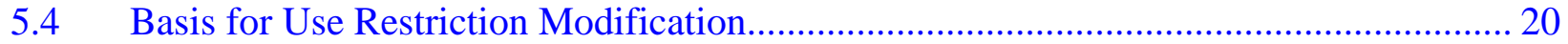

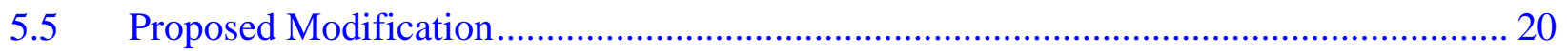




\section{Table of Contents (continued)}

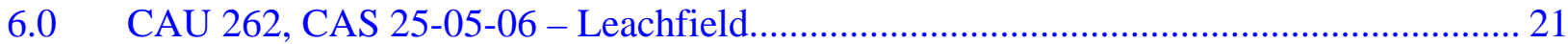

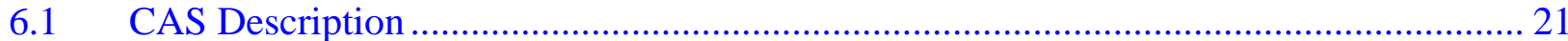

6.2 Current Use Restriction Description........................................................................... 21

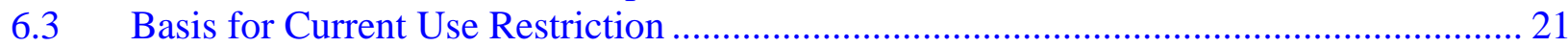

$6.4 \quad$ Basis for Use Restriction Modification............................................................................ 23

$6.5 \quad$ Proposed Modification.................................................................................................... 24

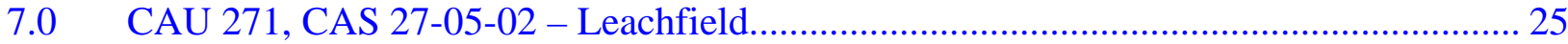

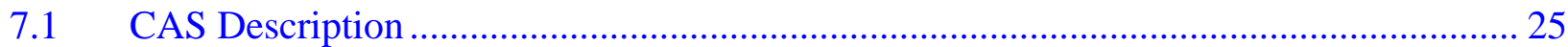

7.2 Current Use Restriction Description............................................................................ 25

7.3 Basis for Current Use Restriction ................................................................................. 25

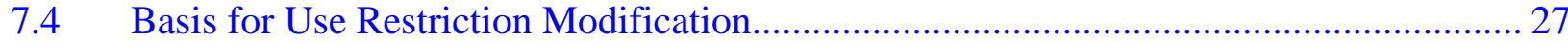

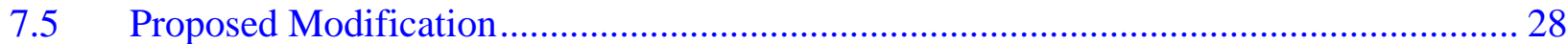

8.0 CAU 321, CAS 22-99-05 - Fuel Storage Area................................................................. 29

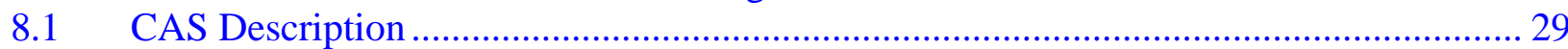

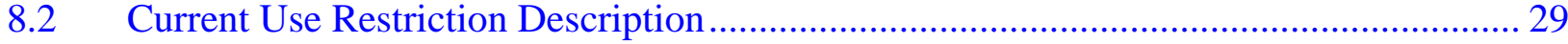

$8.3 \quad$ Basis for Current Use Restriction ................................................................................... 29

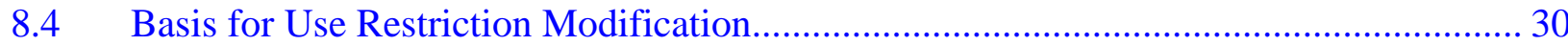

$8.5 \quad$ Proposed Modification................................................................................................. 30

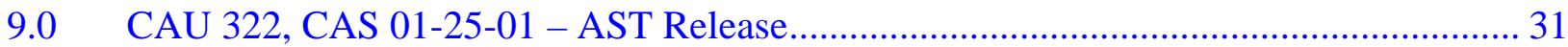

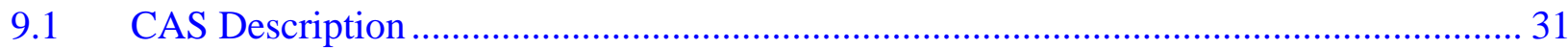

9.2 Current Use Restriction Description.............................................................................. 31

9.3 Basis for Current Use Restriction ................................................................................... 31

9.4 Basis for Use Restriction Modification............................................................................ 32

$9.5 \quad$ Proposed Modification................................................................................................ 32

10.0 CAU 322, CAS 03-25-03 - Mud Plant AST Diesel Release............................................. 33

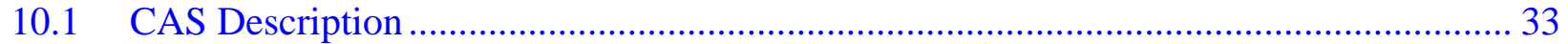

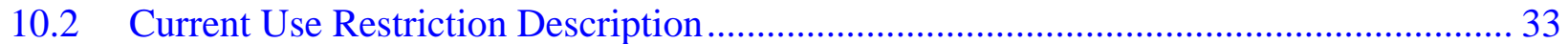

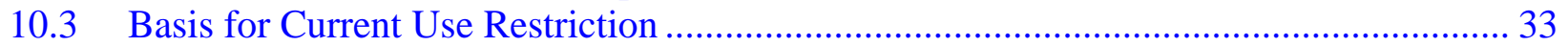

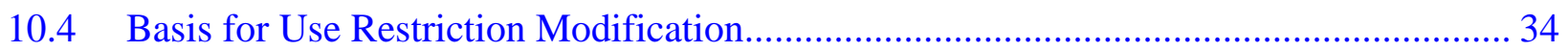

10.5 Proposed Modification............................................................................................. 34

11.0 CAU 335, CAS 06-20-02 - 20-inch Cased Hole............................................................. 35

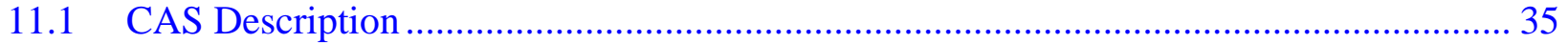

11.2 Current Use Restriction Description.............................................................................. 35

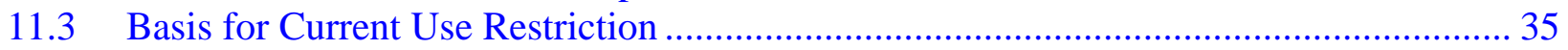

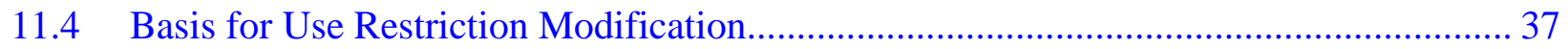

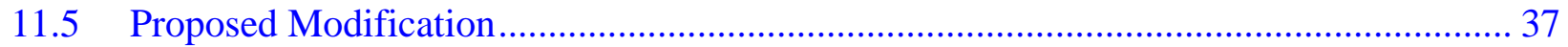

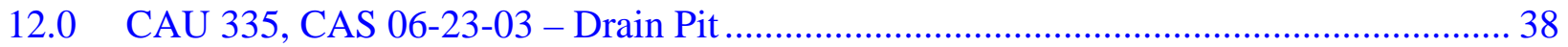

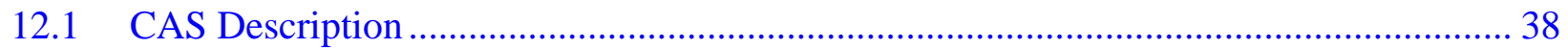




\section{Table of Contents (continued)}

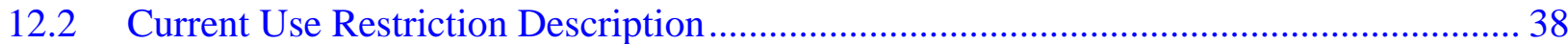

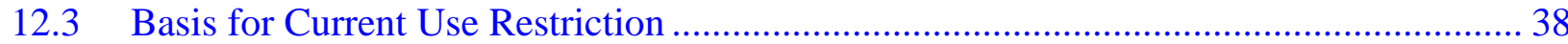

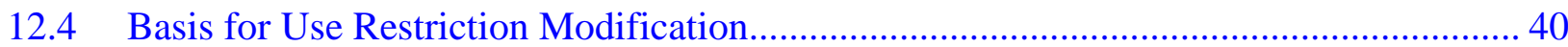

12.5 Proposed Modification.................................................................................................. 40

13.0 CAU 342, CAS 23-56-01 - Former Mercury Fire Training Pit .......................................... 41

13.1 CAS Description ....................................................................................................... 41

13.2 Current Use Restriction Description........................................................................... 41

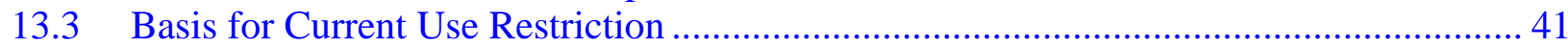

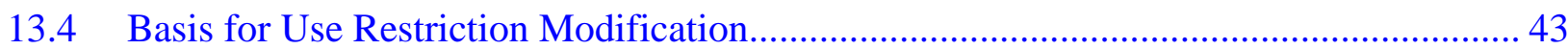

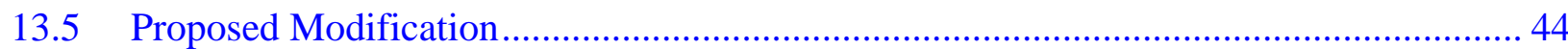

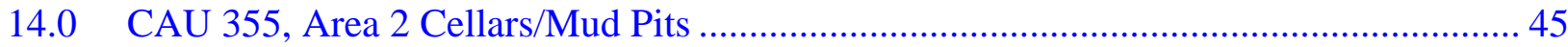

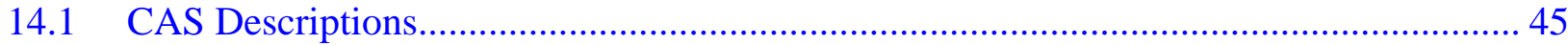

14.2 Current Use Restriction Description............................................................................ 48

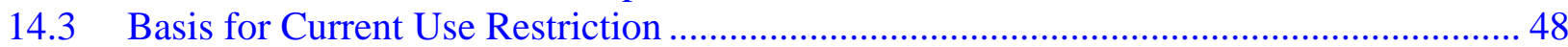

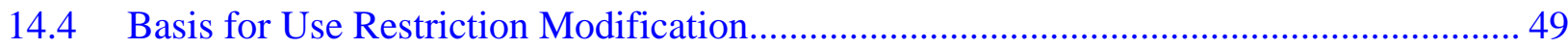

14.5 Proposed Modification.................................................................................................. 49

15.0 CAU 356, CAS 03-04-01 - Area 3 Change House Septic System...................................... 50

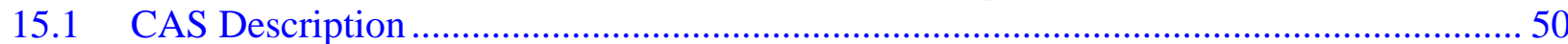

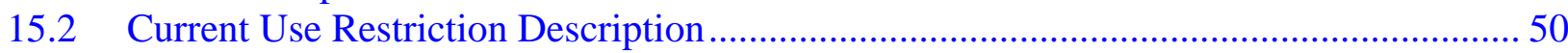

15.3 Basis for Current Use Restriction ................................................................................. 50

15.4 Basis for Use Restriction Modification....................................................................... 51

15.5 Proposed Modification............................................................................................... 52

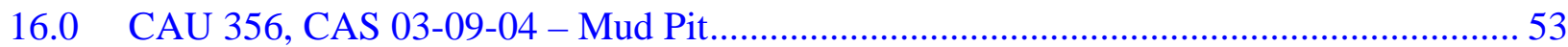

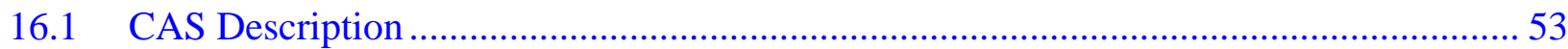

16.2 Current Use Restriction Description............................................................................ 53

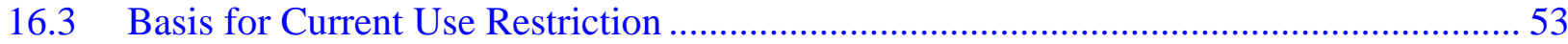

16.4 Basis for Use Restriction Modification.......................................................................... 54

16.5 Proposed Modification.............................................................................................. 54

17.0 CAU 358, Areas 18, 19, 20 Cellars/Mud Pits................................................................... 55

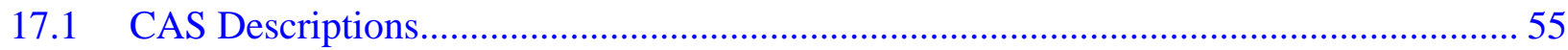

17.2 Current Use Restriction Description............................................................................ 56

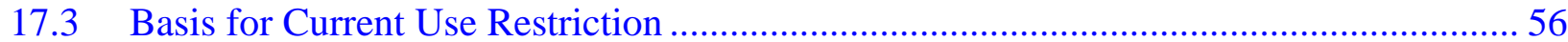

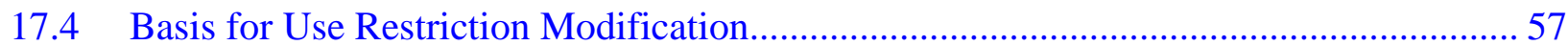

17.5 Proposed Modification.............................................................................................. 57

18.0 CAU 394, CAS 12-25-04 - UST 12-16-2 Waste Oil Release ............................................. 58

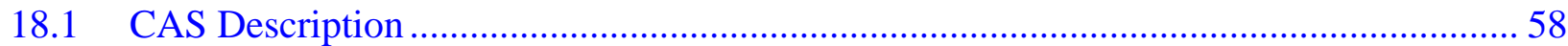

18.2 Current Use Restriction Description........................................................................... 58

18.3 Basis for Current Use Restriction ........................................................................ 58 


\section{Table of Contents (continued)}

18.4 Basis for Use Restriction Modification...................................................................... 59

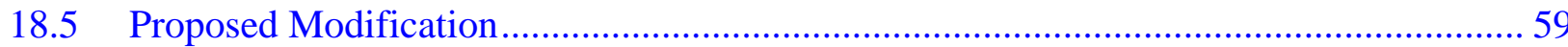

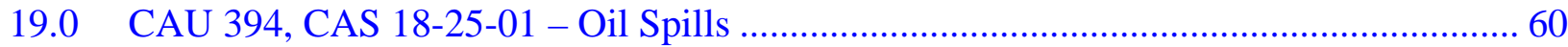

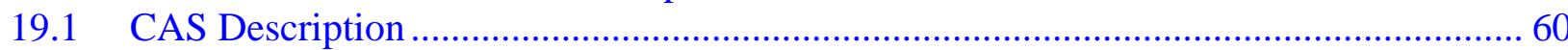

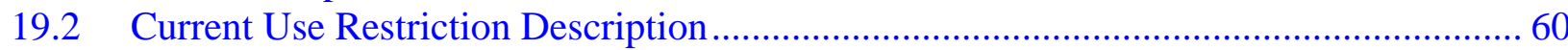

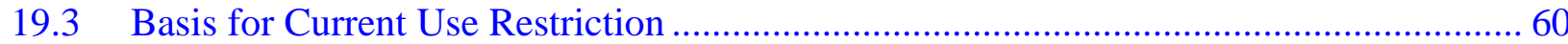

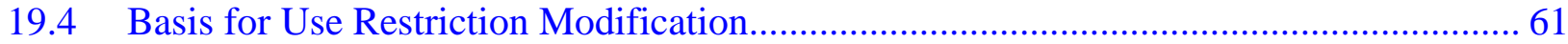

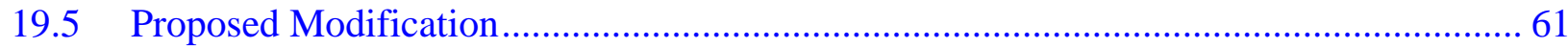

20.0 CAU 394, CAS 18-25-02 - Oil Spills, and CAS 18-25-03 - Oil Spill........................... 62

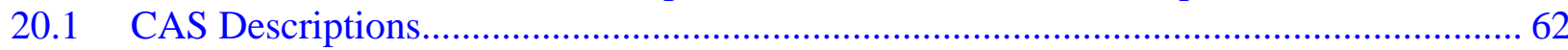

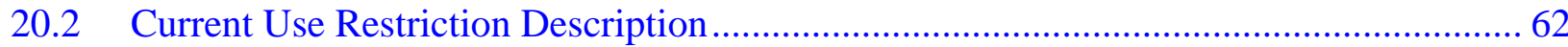

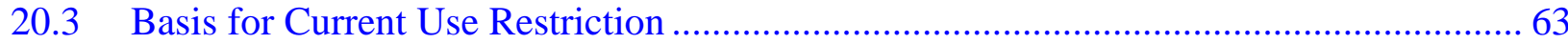

20.4 Basis for Use Restriction Modification..................................................................... 64

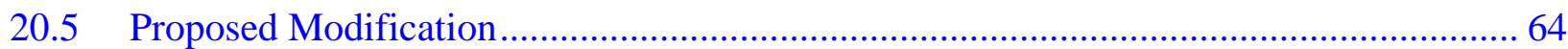

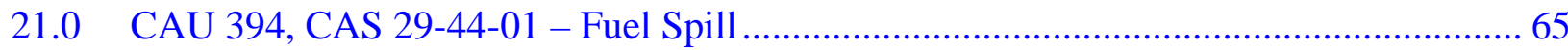

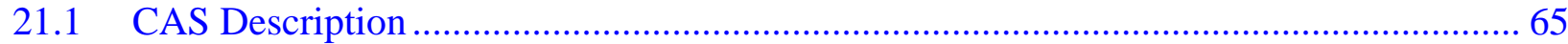

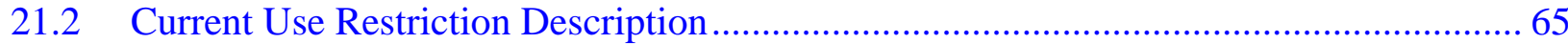

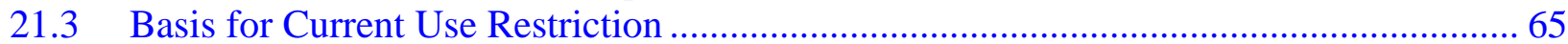

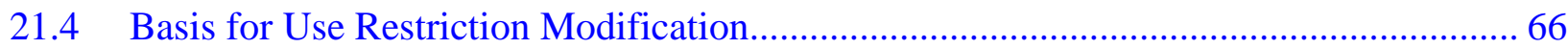

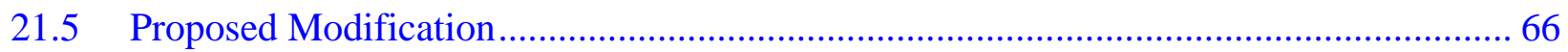

22.0 CAU 398, CAS 25-25-17 - Subsurface Hydraulic Oil Spill ....................................... 67

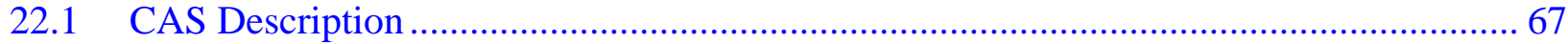

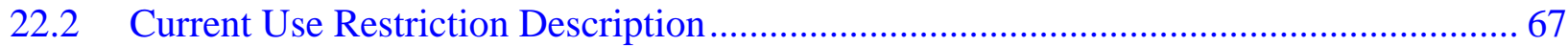

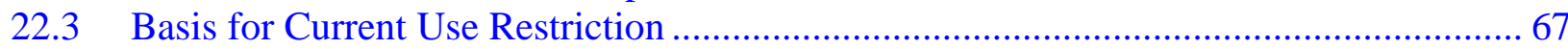

22.4 Basis for Use Restriction Modification................................................................. 68

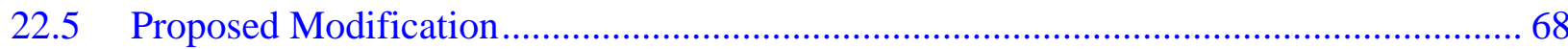

23.0 CAU 404, CAS TA-03-001-TARC - Roller Coaster Lagoons, and TA-21-001-TARC - Roller Coaster N. Disposal Trench ................................................ 69

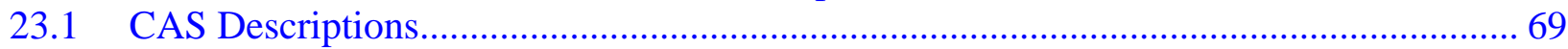

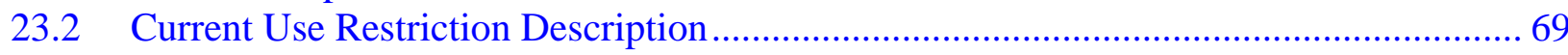

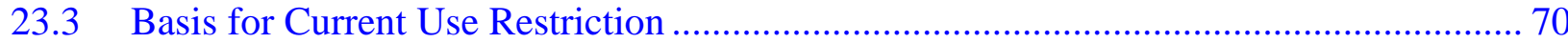

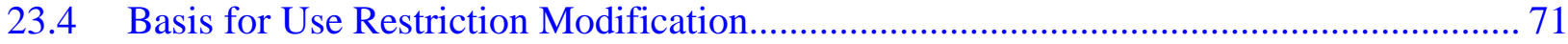

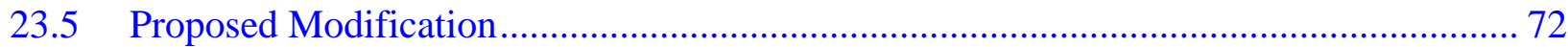

24.0 CAU 423, CAS 03-02-002-0308 - Underground Discharge Point .............................. 73

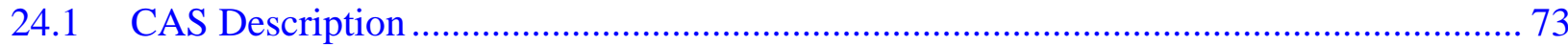

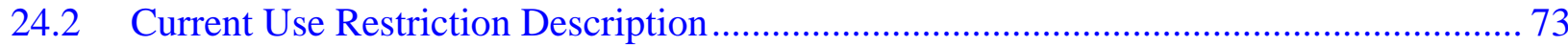

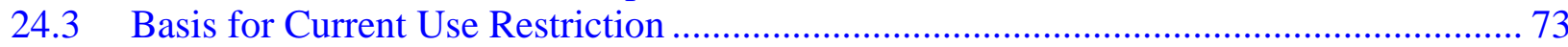

24.4 Basis for Use Restriction Modification......................................................................... 74 


\section{Table of Contents (continued)}

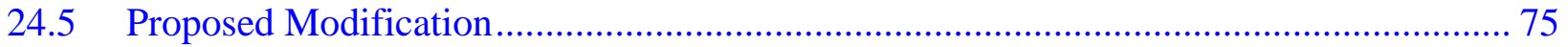

25.0 CAU 427, Area 3 Septic Waste Systems 2, 6 (TTR) ………………………………........ 76

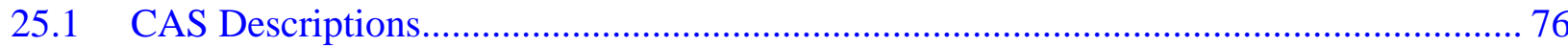

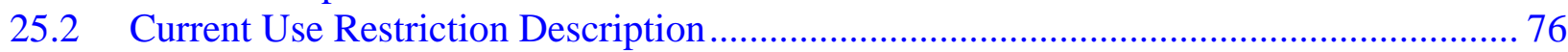

25.3 Basis for Current Use Restriction .................................................................................. 77

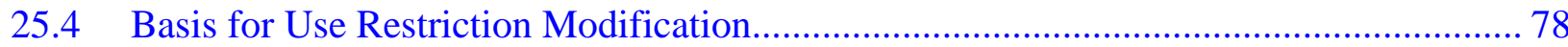

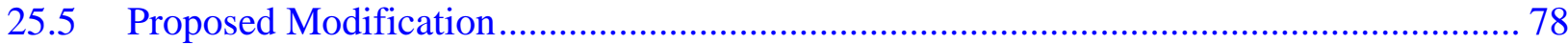

26.0 CAU 429, CAS 03-51-001-0355 - Photo Shop UDP, Drains ………………………........ 79

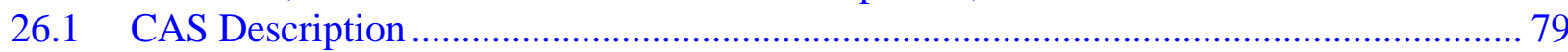

26.2 Current Use Restriction Description.............................................................................. 79

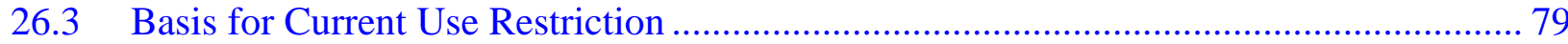

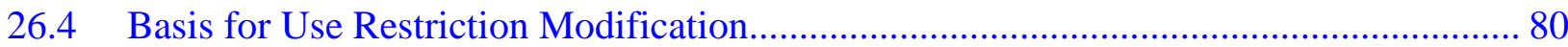

26.5 Proposed Modification................................................................................................ 80

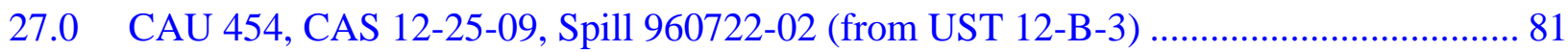

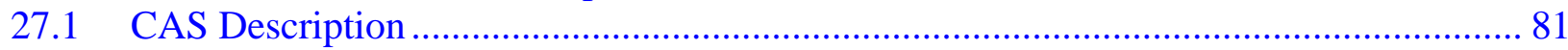

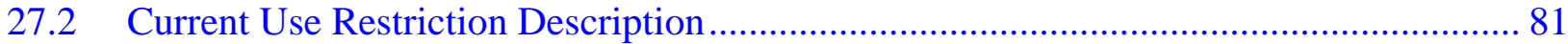

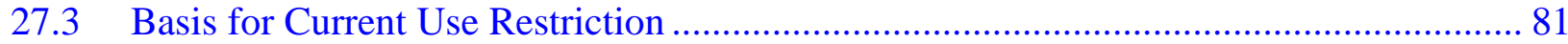

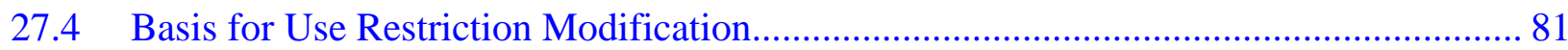

27.5 Proposed Modification....................................................................................................... 81

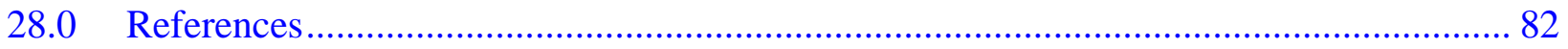




\section{List of Tables}

Number

2-1 Use Restrictions

3-1 Sample Results for COCs at CAS 03-09-06 Used To Establish Current Use

Restriction 12

3-2 Revised Final Action Levels for CAS 03-09-06. 13

4-1 Sample Results for COCs at CAS 03-09-07 Used To Establish Current Use Restriction

4-2 Revised Final Action Levels for CAS 03-09-07 …………………………………....... 17

5-1 Sample Results for COCs at CASs 25-23-01 and 25-23-19 Used To Establish Current Use Restriction

6-1 Sample Results for COCs at CAS 25-05-06 Used To Establish Current Use Restriction.

6-2 Revised Final Action Levels for CAS 25-05-06 ............................................................ 23

7-1 Sample Results for COCs at CAS 27-05-02 Used To Establish Current Use Restriction 26

7-2 Revised Final Action Levels for CAS 27-05-02 …………………………………....... 27

8-1 Sample Results for COCs at CAS 22-99-05 Used To Establish Current Use Restriction ................................................................................................................ 30

9-1 Sample Results for COCs at CAS 01-25-01 Used To Establish Current Use Restriction Sample Location.

10-1 Sample Results for COCs at CAS 03-25-03 Used To Establish Current Use Restriction

11-1 Sample Results for COCs at CAS 06-20-02 Used To Establish Current Use Restriction.....

12-1 Sample Results for COCs at CAS 06-23-03 Used To Establish Current Use Restriction....

13-1 Sample Results for COCs at CAS 23-56-01 Used To Establish Current Use

Restriction

14-1 Sample Results for COCs at CAU 355 Used To Establish

Current Use Restriction.

15-1 Sample Results for COCs at CAS 03-04-01 Used To Establish Current Use

Restriction

15-2 Revised Final Action Levels for CAS 03-04-01 ........................................................... 52

16-1 Sample Results for COCs at CAS 03-09-04 Used To Establish Current Use Restriction....

17-1 Sample Results for COCs at CAU 358 Used To Establish

Current Use Restriction.

18-1 Sample Results for COCs at CAS 12-25-04 Used To Establish Current Use Restriction 


\section{List of Tables (continued)}

Number

19-1 Sample Results for COCs at CAS 18-25-01 Used To Establish Current Use

Restriction

20-1 Sample Results for COCs at CASs 18-25-02 and 18-25-03 Used To Establish

Current Use Restriction

21-1 Sample Results for COCs at CAS 29-44-01 Used To Establish Current Use

Restriction

22-1 Sample Results for COCs at CAS 25-25-17 Used To Establish Current Use

Restriction

23-1 Sample Results for COCs at CAU 404 Used To Establish

Current Use Restriction....

23-2 Revised Final Action Levels for CAU 404 .............................................................. 72

24-1 Sample Results for COCs at CAS 03-02-002-0308 Used To Establish

Current Use Restriction.

25-1 Sample Results for COCs at CAU 427 Used To Establish

Current Use Restriction. 


\section{List of Acronyms and Abbreviations}

Am

AST

ASTM

bgs

BMP

CADD

CAIP

CAS

CAU

COC

COPC

CR

Cs

DDD

DDE

DDT

DOE

DQO

DRO

E-MAD

EPA

$\mathrm{Eu}$

FAL

FD

FFACO
Americium

Aboveground storage tank

American Society for Testing and Materials

Below ground surface

Best management practice

Corrective Action Decision Document

Corrective Action Investigation Plan

Corrective Action Site

Corrective Action Unit

Contaminant of concern

Contaminant of potential concern

Closure Report

Cesium

Dichlorodiphenyl-dichloroethane

Dichlorodiphenyl-dichlorethylene

Dichlorodiphenyl-trichloroethane

U.S. Department of Energy

Data quality objective

Diesel-range organics

Engine Maintenance, Assembly, and Disassembly

U.S. Environmental Protection Agency

Europium

Final action level

Field duplicate

Federal Facility Agreement and Consent Order 


\section{List of Acronyms and Abbreviations (continued)}

\begin{tabular}{|c|c|}
\hline $\mathrm{ft}$ & Foot \\
\hline $\mathrm{ft}^{2}$ & Square foot \\
\hline FTP & Fire Training Pit \\
\hline gal & Gallon \\
\hline GRO & Gasoline-range organics \\
\hline in. & Inch \\
\hline IS & Industrial Sites \\
\hline $\mathrm{m}$ & Meter \\
\hline $\mathrm{mg} / \mathrm{kg}$ & Milligrams per kilogram \\
\hline $\mathrm{mi}$ & Mile \\
\hline $\mathrm{mrem} / \mathrm{yr}$ & Millirem per year \\
\hline NAC & Nevada Administrative Code \\
\hline NDEP & Nevada Division of Environmental Protection \\
\hline NNSA/NSO & $\begin{array}{l}\text { U.S. Department of Energy, National Nuclear Security Administration } \\
\text { Nevada Site Office }\end{array}$ \\
\hline NTS & Nevada Test Site \\
\hline PAL & Preliminary action level \\
\hline PCB & Polychlorinated biphenyl \\
\hline $\mathrm{pCi} / \mathrm{g}$ & Picocuries per gram \\
\hline ppm & Parts per million \\
\hline PRG & Preliminary remediation goal \\
\hline $\mathrm{Pu}$ & Plutonium \\
\hline RBCA & Risk-based corrective action \\
\hline RCRA & Resource Conservation and Recovery Act \\
\hline RESRAD & Residual Radioactive \\
\hline ROTC & Record of Technical Change \\
\hline
\end{tabular}




\section{List of Acronyms and Abbreviations (continued)}

SAFER Streamlined Approach for Environmental Restoration

SNL Sandia National Laboratories

$\mathrm{Sr} \quad$ Strontium

SSTL Site-specific target level

SVOC Semivolatile organic compound

SWS Septic Waste System

TCLP Toxicity Characteristic Leaching Procedure

TPH Total petroleum hydrocarbons

TTR Tonopah Test Range

U Uranium

UCL Upper confidence limit

UDP Underground Discharge Point

UGTA Underground Test Area

UR Use restriction

URMA Underground Radioactive Material Area

UST Underground storage tank

VCA Voluntary Corrective Action

VOC Volatile organic compound

$\mu \mathrm{g} / \mathrm{kg} \quad$ Micrograms per kilogram 


\subsection{Purpose}

Many Federal Facility Agreement and Consent Order (FFACO) Use Restrictions (URs) have been established at various corrective action sites (CASs) as part of FFACO corrective actions (FFACO, 1996; as amended January 2007). Since the signing of the FFACO in 1996, practices and procedures relating to the implementation of risk-based corrective action (RBCA) have evolved. This document is part of an effort to re-evaluate all FFACO URs against the current RBCA criteria (referred to in this document as the Industrial Sites [IS] RBCA process) as defined in the Industrial Sites Project Establishment of Final Action Levels (NNSA/NSO, 2006c). Based on this evaluation, the URs were sorted into the following categories:

1. Where sufficient information exists to determine that the current UR is consistent with the RCBA criteria

2. Where sufficient information exists to determine that the current UR may be removed or downgraded based on RCBA criteria.

3. Where sufficient information does not exist to evaluate the current UR against the RCBA criteria.

After reviewing all the existing FFACO URs, the 49 URs addressed in this document have sufficient information to determine that these current URs may be removed or downgraded based on RCBA criteria. This document presents recommendations on modifications to existing URs that will be consistent with the RCBA criteria. 


\subsection{Process}

The evaluations of URs presented in this document will result in one of the following actions:

1. No action because the risk posed by site contamination is appropriately controlled by the current UR.

2. Removal of the current UR because contamination is not present at the site above risk-based final action levels (FALs).

3. Modification of the current UR to appropriately control risks posed by the site.

All FFACO URs are established to protect site workers and the public from inadvertent contact with contaminants of concern (COCs). A COC is defined as any contaminant that exceeds the corresponding FAL. For most of the existing URs, preliminary action levels (PALs) established at the time of the investigation were used for the FALs (e.g., radionuclide PALs were established as background activities). The PALs have been modified since the signing of the FFACO in 1996. Also, many of the URs were established before the IS RBCA process was developed. The IS RBCA process provides a methodology for determining risk-based FALs. The data used to define the need for the original URs were compared to FALs developed using the current IS RBCA process to re-evaluate the need for a UR and, if needed, the type of UR.

Standard URs (referred to as URs) and administrative URs are the two types of URs that can be established. Administrative URs differ from standard URs in that they do not require onsite postings (i.e., signs) or other physical barriers (e.g., fencing, monuments), and they do not require periodic inspections (see Section 6.2 of the Industrial Sites Project Establishment of Final Action Levels [NNSA/NSO, 2006c]). Administrative URs are applicable to sites where the "Remote Work Area” or “Occasional Use Area” future land-use scenarios are used to calculate a FAL. The administrative UR is used in these circumstances to protect workers from future work activities that would cause an exposure exceeding that used in the calculation of the FAL (e.g., in the event a building is later planned at the location, changing the land use to the "Industrial Area”). This administrative UR would establish the exposure assumption used in the FAL calculation as the exposure limits for the UR. Any proposed activity within this use restricted area that would potentially cause an exposure exceeding the exposure limits would require approval from the Nevada Division of Environmental Protection (NDEP). 


\subsection{Scope}

The 49 URs addressed in this document are listed in Table 2-1 and meet the following criteria:

- $\quad$ The size and depth of the contaminant plume have been adequately defined.

- Where the UR basis included total petroleum hydrocarbons (TPH) contamination, both volatile organic compound (VOC) and semivolatile organic compound (SVOC) results are available for the samples with the maximum TPH concentrations.

Table 2-1

Use Restrictions

(Page 1 of 2)

\begin{tabular}{|c|c|c|c|}
\hline CAU & CAS & Description & Recommended Modification \\
\hline \multirow{2}{*}{34} & 03-09-06 & Mud Disposal Crater & Remove UR \\
\hline & 03-09-07 & Mud Pit & Remove UR \\
\hline \multirow{2}{*}{214} & 25-23-01 & Contaminated Materials & Remove UR \\
\hline & $25-23-19$ & Radioactive Material Storage & Remove UR \\
\hline 262 & $25-05-06$ & Leachfield & Remove UR \\
\hline 271 & $27-05-02$ & Leachfield & Administrative UR \\
\hline 321 & 22-99-05 & Fuel Storage Area & Remove UR \\
\hline \multirow{2}{*}{322} & $01-25-01$ & AST Release & Remove UR \\
\hline & $03-25-03$ & Mud Plant AST Diesel Release & Remove UR \\
\hline \multirow{2}{*}{335} & $06-20-02$ & 20-inch Cased Hole & Remove UR \\
\hline & $06-23-03$ & Drain Pit & Remove UR \\
\hline 342 & $23-56-01$ & Former Mercury Fire Training Pit & Remove UR \\
\hline \multirow{10}{*}{355} & 02-37-01 & Cellar \& Mud Pit & Remove UR \\
\hline & $02-37-03$ & Cellar \& Mud Pit & Remove UR \\
\hline & $02-37-04$ & Cellar \& Mud Pit & Remove UR \\
\hline & $02-37-05$ & Cellar \& Mud Pit & Remove UR \\
\hline & $02-37-06$ & Cellar \& Mud Pit & Remove UR \\
\hline & $02-37-07$ & Cellar \& Mud Pit & Remove UR \\
\hline & $02-37-10$ & Cellar \& Mud Pit & Remove UR \\
\hline & $02-37-11$ & Cellar \& Mud Pit & Remove UR \\
\hline & $02-37-12$ & Cellar \& Mud Pit & Remove UR \\
\hline & $02-37-13$ & Cellar \& Mud Pit & Remove UR \\
\hline
\end{tabular}


Table 2-1

Use Restrictions

(Page 2 of 2)

\begin{tabular}{|c|c|c|c|}
\hline $\begin{array}{l}\text { Corrective } \\
\text { Action Unit }\end{array}$ & $\begin{array}{l}\text { Corrective } \\
\text { Action Site }\end{array}$ & Description & Recommended Modification \\
\hline \multirow{5}{*}{355} & $02-37-14$ & Cellar \& Mud Pit & Remove UR \\
\hline & $02-37-15$ & Cellar \& Mud Pit & Remove UR \\
\hline & $02-37-16$ & Cellar \& Mud Pit & Remove UR \\
\hline & $02-37-17$ & Cellar & Remove UR \\
\hline & $02-37-18$ & Cellar \& Tanks & Remove UR \\
\hline \multirow{2}{*}{356} & 03-04-01 & Area 3 Change House Septic System & Remove UR \\
\hline & 03-09-04 & Mud Pit & Remove UR \\
\hline \multirow{7}{*}{358} & $20-23-02$ & Postshot Cellar & Remove UR \\
\hline & $20-23-03$ & Cellar & Remove UR \\
\hline & $20-23-04$ & Postshot Cellar & Remove UR \\
\hline & $20-23-05$ & Postshot Cellar & Remove UR \\
\hline & $20-23-06$ & Cellar & Remove UR \\
\hline & $20-37-01$ & Cellar \& Mud Pit & Remove UR \\
\hline & $20-37-05$ & Cellar & Remove UR \\
\hline \multirow{5}{*}{394} & $12-25-04$ & UST 12-16-2 Waste Oil Release & Remove UR \\
\hline & $18-25-01$ & Oil Spills & Remove UR \\
\hline & $18-25-02$ & Oil Spills & Remove UR \\
\hline & $18-25-03$ & Oil Spill & Remove UR \\
\hline & $29-44-01$ & Fuel Spill & Remove UR \\
\hline 398 & $25-25-17$ & Subsurface Hydraulic Oil Spill & Remove UR \\
\hline \multirow{2}{*}{404} & $\begin{array}{c}\text { TA-03-001- } \\
\text { TARC }\end{array}$ & Roller Coaster Lagoons & Administrative UR \\
\hline & $\begin{array}{c}\text { TA-21-001- } \\
\text { TARC }\end{array}$ & Roller Coaster N. Disposal Trench & Administrative UR \\
\hline 423 & 03-02-002-0308 & Underground Discharge Point & Remove UR \\
\hline \multirow{2}{*}{427} & 03-05-002-SW02 & Septic Waste System & Remove UR \\
\hline & 03-05-002-SW06 & Septic Waste System & Remove UR \\
\hline 429 & 03-51-001-0355 & Photo Shop UDP, Drains & Remove UR \\
\hline 454 & $12-25-09$ & Spill 960722-02 (from UST 12-B-3) & Remove UR \\
\hline
\end{tabular}

AST = Aboveground storage tank.

UDP $=$ Underground Discharge Point

UR $=$ Use restriction 
Table 2-1 also includes the recommended modifications to each UR. These sites are addressed in Sections 3.0 through 27.0 to include the following information:

- The CAS description as listed in the FFACO database.

- $\quad$ The current UR description as listed in the corresponding FFACO closure document.

- The basis for current UR, as listed in the corresponding FFACO closure document, including the analytical results driving the decision.

- $\quad$ The basis for UR modification based on the current RBCA process.

\subsection{Action Levels}

The current IS RBCA process used to establish FALs is described in the Industrial Sites Project Establishment of Final Action Levels (NNSA/NSO, 2006c). This process conforms to Nevada Administrative Code (NAC) Section 445A.227 (NAC, 2006a), which lists the requirements for sites with soil contamination. For the evaluation of corrective actions, NAC Section 445A.22705 (NAC, 2006b) recommends the use of American Society for Testing and Materials (ASTM) Method E 1739 (ASTM, 1995) to "conduct an evaluation of the site, based on the risk it poses to public health and the environment, to determine the necessary remediation standards (i.e., FALs) or to establish that corrective action is not necessary.”

This RBCA process defines three tiers (or levels) of evaluation involving increasingly sophisticated analyses:

- Tier 1 evaluation - Sample results from source areas (highest concentrations) are compared to action levels based on generic (non-site-specific) conditions (i.e., PALs). The FALs may then be established as the Tier 1 action levels, or the FALs may be calculated using a Tier 2 evaluation.

- $\quad$ Tier 2 evaluation - Conducted by calculating Tier 2 site-specific target levels (SSTLs) using site-specific information as inputs to the same or similar methodology used to calculate Tier 1 action levels. The Tier 2 SSTLs are then compared to individual sample results from reasonable points of exposure (as opposed to the source areas as is done in Tier 1) on a point-by-point basis. Total TPH concentrations will not be used for risk-based decisions under Tier 2 or Tier 3. Rather, the individual COCs will be compared to the SSTLs.

- $\quad$ Tier 3 evaluation - Conducted by calculating Tier 3 SSTLs on the basis of more sophisticated risk analyses using methodologies described in Method E 1739-95 that consider site-, pathway-, and receptor-specific parameters. 
The comparison of laboratory results to the revised FALs is used to evaluate the need for and the type of UR at each site. The revised FALs are defined (along with the basis for their definition) in each of the subsequent UR sections.

\subsubsection{Tier 1-Based FALs}

All FALs based on a Tier 1 evaluation were defined as the PALs listed in the following subsections.

\subsubsection{Chemical PALs}

Except as noted herein, the chemical PALs are defined as the U.S. Environmental Protection Agency (EPA) Region 9 Risk-Based Preliminary Remediation Goals (PRGs) for chemical contaminants in industrial soils (EPA, 2004). Background concentrations for Resource Conservation and Recovery Act (RCRA) metals and zinc will be used instead of PRGs when natural background concentrations exceed the PRG, which is often the case with arsenic on the Nevada Test Site (NTS). Background is considered the average concentration plus two standard deviations of the average concentration for sediment samples collected by the Nevada Bureau of Mines and Geology throughout the Nevada Test and Training Range (formerly the Nellis Air Force Range) (NBMG, 1998; Moore, 1999). For detected chemical contaminants of potential concern (COPCs) without established PRGs, the protocol used by the EPA Region 9 in establishing PRGs (or similar) will be used to establish PALs. If used, this process will be documented in the investigation report.

\subsubsection{Total Petroleum Hydrocarbon PALs}

The PAL for TPH is 100 parts per million (ppm) as listed in NAC 445A.2272 (NAC, 2006c).

\subsubsection{Radionuclide PALs}

The PALs for radiological contaminants (other than tritium) are based on the National Council on Radiation Protection and Measurements Report No. 129 recommended screening limits for construction, commercial, and industrial land-use scenarios (NCRP, 1999) scaled to a 25-millirem-per-year (mrem/yr) dose constraint (Murphy, 2004) and the generic guidelines for residual concentration of radionuclides in U.S. Department of Energy (DOE) Order 5400.5 (DOE, 1993). These PALs are based on the construction, commercial, and industrial land-use scenarios provided in the guidance and are appropriate for the NTS based on future land use scenarios (NCRP, 1999). The PAL for tritium is based on the Underground Test Area (UGTA) 
Project limit of 400,000 picocuries per liter for discharge of water containing tritium (NNSA/NV, 2002c).

\subsubsection{Tier 2-Based FALs}

All FALs established based on a Tier 2 evaluation were calculated using one of the following site-specific exposure scenarios, as defined in the IS RBCA (NNSA/NSO, 2006c):

- Industrial Area - Worker will be exposed to the site full time (225 days per year, 10 hours per day for 25 years). This exposure scenario is for sites where workers are present full-time (e.g., a site located at Mercury).

- $\quad$ Remote Work Area - Worker will be exposed to the site part-time (up to 336 hours per year for 25 years). This exposure scenario is for sites where workers are present parttime (e.g., a site located near a substation that workers might visit for inspection and maintenance).

- Occasional Use Area - Worker will be exposed to the site occasionally (up to 80 hours per year for 5 years). This exposure scenario is for sites where workers are present occasionally (e.g., an open desert area with no facilities or regular work areas).

The Tier 2 SSTLs are compared to individual sample results from reasonable points of exposure (as opposed to the source areas as is done in Tier 1) on a point-by-point basis. Tier 2-based FALs do not include an action level for petroleum hydrocarbon as a whole (e.g., TPH). Instead, the risk posed by TPH (not yet established) is addressed as the risk posed by the individual hazardous constituents of TPH present at the site.

The following COPCs are defined as the hazardous constituents of TPH diesel:

- 1,3,5-Trimethylbenzene

- 2-Methylnaphthalene

- Benzo(a)anthracene

- Benzene

- Benzo(a)pyrene

- Ethylbenzene

- Naphthalene

- Toluene

- Xylenes

- $n$-Butylbenzene

- n-Propylbenzene

- Benzo(k)fluoranthene

- Benzo(b)fluoranthene 
- Fluorene

- Phenanthrene

- Fluoranthene

- Pyrene

- Chrysene

- Anthracene

- $\operatorname{Benzo(g,h,i)perylene~}$

The following COPCs are defined as the hazardous constituents of TPH gasoline:

- Benzene

- Ethylbenzene

- Toluene

- Xylenes

The hazardous constituents of TPH diesel and TPH gasoline are included in the list of reported analytical results from the VOC and SVOC analytical methods. Therefore, when all SVOC and VOC analyte results are below PALs, TPH diesel and TPH gasoline can be considered to be below PALs.

\subsubsection{Tier 3-Based FALs}

If appropriate, a Tier 3 evaluation may be conducted by calculating Tier 3 SSTLs on the basis of more sophisticated risk analyses using methodologies described in Method E 1739-95, such as Groundwater Modeling System software (BYU, 1999), that consider site-, pathway-, and receptor-specific parameters. Tier 3 evaluation is much more complex than Tier 1 and 2 evaluations because it may include additional site characterization, probabilistic evaluations, and sophisticated chemical fate/transport models. The Tier 3 SSTLs are then compared to the 95 percent upper confidence limit (UCL) of the mean of sample results, from the points of compliance, as defined in ASTM Method E 1739-95. Contaminant concentrations or activities exceeding Tier 3 SSTLs require corrective action. If a Tier 3 evaluation is conducted, the calculations used to derive the SSTLs and the UCL of the means will be provided as an appendix to the report.

No FALs were established based on a Tier 3 evaluation for the CASs described in this document.

\subsubsection{Multiple Constituent Analysis}

Any nonradionuclide FAL based on a Tier 2 or Tier 3 evaluation will also be subject to an evaluation of additive risk to the receptor by multiple constituents at sites where contamination 
exceeds PALs, but does not exceed FALs. This will address a potential situation where all constituents present at a site are below the individual FALs (and, therefore, the data decision may otherwise be that no further action is required), but the additive effect of multiple constituents may pose an unacceptable risk to the receptor. This assessment will be identified in the UR Modification Proposal as a multiple constituent analysis. When required, a multiple constituent analysis will be conducted, as defined in Industrial Sites Project Establishment of Final Action Levels, for carcinogenic risk and/or toxicity using all of the constituents exceeding risk-based screening levels that have either a slope factor or a reference dose (i.e., that are either carcinogenic or toxic) (NNSA/NSO, 2006c).

A multiple constituent analysis will not be conducted for radioactive dose because the Residual Radioactive (RESRAD) computer code back-calculates SSTLs, from total dose to the receptor, based on the combination of radioactive constituents present at the site.

A multiple constituent analysis will be conducted by summing the ratios of each constituent concentration exceeding a PAL to their corresponding Tier 2 or Tier 3 carcinogenic- or toxicity-based FAL. If the sum of the ratios exceeds 1.0, then the data quality objective (DQO) decision will be modified to corrective action required. Any multiple constituent analyses that were conducted are identified in the CAS-specific sections.

\subsection{Modified Use Restriction Decision Basis}

The recommendation to modify the UR will be based on the following decision statements:

- If the site contains a contaminant exceeding a FAL, based on the site-specific foreseeable future land-use exposure scenario (see Section 2.2.2), the current FFACO UR will remain.

Otherwise:

- If the site does not contain a contaminant exceeding a FAL, based on the site-specific exposure scenario, the UR will be removed.

Otherwise:

- If the site contains a contaminant exceeding a FAL, based on the Industrial Area exposure scenario, an administrative UR will be implemented. Changing to an administrative UR would eliminate ongoing inspection and maintenance requirements (e.g., no requirement for fencing or signage), and would allow worker access to the site for temporary or intermittent site uses, based on the site-specific exposure scenario. 


\subsection{Modification of Use Restrictions}

All FFACO URs were established in an approved FFACO closure document (e.g., Corrective Action Decision Document [CADD]/Closure Report [CR] or CR).

Changes to approved FFACO documents are in the form of an addendum, an errata sheet, or Record of Technical Change (ROTC). Addenda are used when extensive corrections/additions to a section or multiple sections of an FFACO document are necessary.

Approval of this document will constitute approval of the UR modifications recommended for each UR addressed herein. Following approval, an addendum to each of the associated closure documents (that originally established each UR) will be prepared and submitted as DOE, National Nuclear Security Administration Nevada Site Office (NNSA/NSO) FFACO records. These addenda will consist of:

- A cover page referring the reader to this document for additional information.

- The cover and signature pages of this document.

- The NDEP approval letter.

- The corresponding section of this document.

As applicable, requirements for inspecting and maintaining the modified URs will be lifted, and the postings and signage, at each site specific to the FFACO UR, will be removed. Fencing and posting may be present at these sites that are unrelated to the FFACO UR, such as for radiological control purposes, as required by the NV/YMP Radiological Control Manual (NNSA/NSO, 2004f). Modification of any UR will not affect or modify requirements for fencing, posting, or monitoring at any of these sites. 


\subsection{CAU 34, CAS 03-09-06 - Mud Disposal Crater}

\subsection{CAS Description}

The Mud Disposal Crater is located approximately 25 feet (ft) north of the Area 3 Mud Plant Building, approximately 24 miles (mi) north of Mercury, Nevada, and east of Mercury Highway on Road 3-03. The Mud Disposal Crater received drilling waste and excess mud from the mud plant. The crater is approximately $314 \mathrm{ft}$ in diameter, $42 \mathrm{ft}$ deep, and was created by a 1962 underground nuclear detonation called the Chinchilla test. Later in 1962, after the test, the crater was used to mix and store mud. After 1962, the crater was used for disposal; receiving waste from Baker tanks, vacuum trucks, and the mud plant. The Mud Disposal Crater also received wastewater from the mud plant floor drains and from cleaning and flushing of mix tanks. The crater received exotic mud mixtures, including asbestos and chromate muds, used for experimentation at the mud plant between 1970 and 1972. Sometime between 1992 and 1994, the disposal of used mud and wastewater ceased (DOE/NV, 2001a).

\subsection{Current Use Restriction Description}

The future use of any land affected by this UR is restricted from any DOE or Air Force activity that may alter or modify the containment control as approved by the state and identified in the Corrective Action Unit (CAU) CR or other CAU documentation unless appropriate concurrence is obtained in advance. There are no annual monitoring or inspection requirements associated with the UR (NNSA/NV, 2002b).

\subsection{Basis for Current Use Restriction}

Samples were analyzed for TPH diesel-range organics (DRO), total VOCs, total SVOCs, total RCRA metals, polychlorinated biphenyls (PCBs), isotopic uranium (U), isotopic plutonium (Pu), strontium (Sr)-90, americium (Am)-241, and gamma spectroscopy. The analytical results for soil samples collected at the Mud Disposal Crater indicated the presence of TPH (DRO) contamination exceeding the NDEP action level of 100 milligrams per kilogram (mg/kg) at five locations. No VOCs or SVOCs were detected above PALs. Arsenic was detected above the PAL of $2.7 \mathrm{mg} / \mathrm{kg}$ in 25 of the 30 samples analyzed, but all concentrations were within the range considered representative of ambient conditions at the site. Therefore, arsenic is not considered to be a basis for this UR. The radionuclides Am-241, U-235, Pu-238, and Pu-239/240 exceeded their respective PALs. The PALs for the radionuclides were established in the Corrective Action 
Investigation Plan (CAIP) as any activity distinguishable from undisturbed background activity (DOE/NV, 2001a).

Table 3-1 contains analytical results of all COCs at CAS 03-09-06 that are the basis for the current UR. The sample matrix for all samples is soil.

Table 3-1

Sample Results for COCs at CAS 03-09-06 Used To Establish Current Use Restriction

\begin{tabular}{|c|c|c|c|c|c|c|}
\hline \multirow{2}{*}{ Sample ID } & \multirow{2}{*}{$\begin{array}{l}\text { Depth } \\
\text { (ft bgs) }\end{array}$} & TPH (DRO) & Am-241 & U-235 & Pu-238 & Pu-239/240 \\
\hline & & $\begin{array}{c}\mathrm{PAL} \\
100 \mathrm{mg} / \mathrm{kg}\end{array}$ & $\begin{array}{c}\text { PAL } \\
0.05 \mathrm{pCi} / \mathrm{g}\end{array}$ & $\begin{array}{c}\text { PAL } \\
0.07 \mathrm{pCi} / \mathrm{g}\end{array}$ & $\begin{array}{c}\text { PAL } \\
0.05 \mathrm{pCi} / \mathrm{g}\end{array}$ & $\begin{array}{c}\text { PAL } \\
0.106 \mathrm{pCi} / \mathrm{g}\end{array}$ \\
\hline DC0101 & $1-2$ & -- & $0.94 \pm 0.17$ & -- & $\begin{array}{c}0.113 \pm \\
0.039\end{array}$ & $5.97 \pm 0.85$ \\
\hline DC0205 & $5-7$ & 180 & -- & -- & -- & -- \\
\hline DC0208 & $8-10$ & -- & $0.94 \pm 0.18$ & -- & $\begin{array}{c}0.085 \pm \\
0.034\end{array}$ & $7 \pm 1.0$ \\
\hline DC0300 & $0-0.5$ & 110 & -- & -- & -- & -- \\
\hline DC0606 & $6.5-7.5$ & -- & $0.81 \pm 0.16$ & -- & $\begin{array}{l}0.139 \pm \\
0.045\end{array}$ & $6.61 \pm 0.95$ \\
\hline DC0799 & $1-6$ & 190 & -- & -- & -- & -- \\
\hline DC0911 & $11.5-12.5$ & -- & $0.97 \pm 0.18$ & -- & $\begin{array}{c}0.078 \pm \\
0.032\end{array}$ & $7.1 \pm 1.0$ \\
\hline DC1102 & $2.5-3.5$ & $5,300(\mathrm{~J})$ & -- & -- & -- & -- \\
\hline DC1104 & $4.5-5.5$ & $8,000(\mathrm{~J})$ & -- & -- & -- & -- \\
\hline DC1211 & $11-13$ & -- & $\begin{array}{c}0.255 \pm \\
0.069\end{array}$ & -- & -- & $1.65 \pm 0.27$ \\
\hline DC0799 & $1-6$ & -- & $\begin{array}{c}0.07 \pm \\
0.025(\mathrm{~J})\end{array}$ & $\begin{array}{l}0.145 \pm \\
0.052\end{array}$ & -- & $0.38 \pm 0.086$ \\
\hline
\end{tabular}

$\mathrm{Am}=$ Americium

bgs $=$ Below ground surface

$\mathrm{DRO}=$ Diesel-range organics

$\mathrm{ft}=$ Foot

ID = Identification

$\mathrm{J}=$ Estimated value

-- = No detects above action levels $\mathrm{mg} / \mathrm{kg}=$ Milligrams per kilogram

$\mathrm{PAL}=$ Preliminary action level $\mathrm{pCi} / \mathrm{g}=$ Picocuries per gram

$\mathrm{Pu}=$ Plutonium

$\mathrm{TPH}=$ Total petroleum hydrocarbons

$\mathrm{U}=$ Uranium 


\subsection{Basis for Use Restriction Modification}

The revised FALs for radionuclides listed in Table 3-2 were established based on the PALs presented in Section 2.2.1. The revised FALs associated with the TPH contamination were established based on the PALs of the hazardous constituents of TPH (DRO) described in Section 2.2.2. Hazardous constituents of TPH were not detected in any of the samples at concentrations greater than their respective PALs (DOE/NV, 2001a). Therefore, no contaminants are present at this site in concentrations exceeding the revised FALs. All revised FALs were established at the PAL concentrations.

Table 3-2 presents the sample results that are the basis for the current UR and demonstrate that no results exceed the revised FALs.

Table 3-2

Revised Final Action Levels for CAS 03-09-06

\begin{tabular}{|c|c|c|c|c|c|}
\hline \multirow{2}{*}{ Sample ID } & \multirow{2}{*}{$\begin{array}{l}\text { Depth } \\
\text { (ft bgs) }\end{array}$} & Am-241 & U-235 & Pu-238 & Pu-239 \\
\hline & & $\begin{array}{c}\text { Revised FAL } \\
12.7 \mathrm{pCi} / \mathrm{g}\end{array}$ & $\begin{array}{c}\text { Revised FAL } \\
17.6 \mathrm{pCi} / \mathrm{g}\end{array}$ & $\begin{array}{c}\text { Revised FAL } \\
13 \mathrm{pCi} / \mathrm{g}\end{array}$ & $\begin{array}{c}\text { Revised FAL } \\
12.7 \mathrm{pCi} / \mathrm{g}\end{array}$ \\
\hline DC0101 & $1-2$ & $0.94 \pm 0.17$ & -- & $0.113 \pm 0.039$ & $5.97 \pm 0.85$ \\
\hline DC0208 & $8-10$ & $0.94 \pm 0.18$ & -- & $0.085 \pm 0.034$ & $7 \pm 1.0$ \\
\hline DC0606 & $6.5-7.5$ & $0.81 \pm 0.16$ & -- & $0.139 \pm 0.045$ & $6.61 \pm 0.95$ \\
\hline DC0911 & $11.5-12.5$ & $0.97 \pm 0.18$ & -- & $0.078 \pm 0.032$ & $7.1 \pm 1.0$ \\
\hline DC1211 & $11-13$ & $0.255 \pm 0.069$ & -- & -- & $1.65 \pm 0.27$ \\
\hline DC0799 & $1-6$ & $0.07 \pm 0.025(\mathrm{~J})$ & $0.145 \pm 0.052$ & -- & $0.38 \pm 0.086$ \\
\hline
\end{tabular}

Am = Americium

ID = Identification

bgs $=$ Below ground surface

pCi/g = Picocuries per gram

$\mathrm{FAL}=$ Final action level

$\mathrm{Pu}=$ Plutonium

$\mathrm{ft}=$ Foot

$\mathbf{U}=$ Uranium

$\mathrm{J}=$ Estimated value

-- = No detects above original action levels

\subsection{Proposed Modification}

Remove the FFACO UR and associated fencing and postings from this CAS. 


\subsection{CAU 34, CAS 03-09-07 - Mud Pit}

\subsection{CAS Description}

Corrective Action Site 03-09-07, Mud Pit, is located south of the Area 3 camp and north of the U3gd crater. The Mud Pit possibly received pre- and post-test drill waste and drill yard waste. The site consists of a mud pit approximately 315 by $245 \mathrm{ft}$ with an approximate 100-by-40-ft internal bermed area at the northeast corner of the large pit. The interior bermed area was used for disposal of excess mud from washing drilling equipment, specifically Baker and Shaker tanks. The mud pit was used for disposal from 1968 to sometime before 1974, at which time the U3ag crater (CAS 03-09-06) was used for excess mud disposal. The mud pit is currently inactive (DOE/NV, 2001a).

\subsection{Current Use Restriction Description}

The future use of any land affected by this UR is restricted from any DOE or Air Force activity that may alter or modify the containment control, as approved by the state and identified in the CAU CR or other CAU documentation, unless appropriate concurrence is obtained in advance. There are no annual monitoring or inspection requirements associated with the UR (NNSA/NV, 2002b).

\subsection{Basis for Current Use Restriction}

Samples were analyzed for TPH (DRO), total VOCs, total SVOCs, total RCRA metals, PCBs, isotopic U, isotopic Pu, Sr-90, Am-241, and gamma spectroscopy. No VOCs or SVOCs were detected above PALs. The analytical results for soil samples collected at the Mud Pit indicated the presence of TPH (DRO) contamination exceeding the NDEP action level of $100 \mathrm{mg} / \mathrm{kg}$ at 12 locations, and the presence of TPH gasoline-range organics (GRO) contamination exceeding the NDEP action level of $100 \mathrm{mg} / \mathrm{kg}$ at one location. Arsenic was detected above the PAL of $2.7 \mathrm{mg} / \mathrm{kg}$ in 44 of the 46 samples analyzed, but all concentrations were within the range considered representative of ambient conditions at the site. Therefore, arsenic is not considered to be a basis for this UR. The radionuclides Am-241, europium (Eu)-152, U-235, Pu-238, and Pu-239/240 exceeded their respective PALs. The PALs for the radionuclides were established in the CAIP as any activity distinguishable from undisturbed background activity (DOE/NV, 2001a). 
Table 4-1 contains analytical results of all COCs at CAS 03-09-07 that are the basis for the current UR. The sample matrix for all samples is soil.

Table 4-1

Sample Results for COCs at CAS 03-09-07 Used To Establish Current Use Restriction (Page 1 of 2)

\begin{tabular}{|c|c|c|c|c|c|c|c|c|}
\hline \multirow[b]{2}{*}{ Sample ID } & \multirow{2}{*}{$\begin{array}{c}\text { Depth (ft } \\
\text { bgs) }\end{array}$} & $\begin{array}{c}\text { TPH } \\
\text { (DRO) }\end{array}$ & TPH (GRO) & Am-241 & Eu-152 & U-235 & Pu-238 & Pu-239/240 \\
\hline & & $\begin{array}{c}\text { PAL } \\
100 \mathrm{mg} / \mathrm{kg}\end{array}$ & $\begin{array}{c}\text { PAL } \\
100 \mathrm{mg} / \mathrm{kg}\end{array}$ & $\begin{array}{c}\text { PAL } \\
0.05 \mathrm{pCi} / \mathrm{g}\end{array}$ & $\begin{array}{c}\text { PAL } \\
\text { Not } \\
\text { Identified }\end{array}$ & $\begin{array}{c}\text { PAL } \\
0.07 \mathrm{pCi} / \mathrm{g}\end{array}$ & $\begin{array}{c}\text { PAL } \\
0.05 \mathrm{pCi} / \mathrm{g}\end{array}$ & $\begin{array}{c}\text { PAL } \\
0.106 \mathrm{pCi} / \mathrm{g}\end{array}$ \\
\hline MP0108 & $8-10$ & -- & -- & -- & $\begin{array}{c}1.25 \pm 0.48 \\
(\mathrm{~J})\end{array}$ & -- & -- & -- \\
\hline MP0500 & $0-0.5$ & -- & -- & -- & $6.1 \pm 1.2$ & -- & -- & -- \\
\hline MP0507 & $7.5-9.5$ & 140 & -- & -- & -- & -- & -- & -- \\
\hline MP0600 & $0-1$ & -- & -- & $\begin{array}{c}0.212 \pm 0.066 \\
(\mathrm{~J})\end{array}$ & $1.97 \pm 0.48$ & $\begin{array}{c}0.079 \pm \\
0.036\end{array}$ & $\begin{array}{c}0.193 \pm \\
0.053\end{array}$ & $1.16 \pm 0.19$ \\
\hline MP0601 & $1-3$ & $48,000(\mathrm{~J})$ & 1,800 & -- & -- & -- & -- & -- \\
\hline MP0703 & $3-5$ & $11,000(\mathrm{~J})$ & -- & -- & -- & -- & -- & -- \\
\hline MP0800 & $0-0.5$ & -- & -- & $2.00 \pm 0.72$ & -- & -- & -- & $0.43 \pm 0.09$ \\
\hline MP0808 & $8-10$ & 2,300 & -- & -- & -- & -- & -- & -- \\
\hline MP0900 & $0-1$ & -- & -- & $\begin{array}{c}0.125 \pm 0.032 \\
(\mathrm{~J})\end{array}$ & $\begin{array}{c}1.26 \pm 0.45 \\
(\mathrm{~J})\end{array}$ & $\begin{array}{c}0.072 \pm \\
0.038\end{array}$ & -- & $0.18 \pm 0.05$ \\
\hline MP1001 & $1-3$ & 290 & -- & -- & -- & -- & -- & -- \\
\hline MP1103 & $3-5$ & 930 & -- & -- & -- & -- & -- & -- \\
\hline MP1200 & $0-1$ & 210 & -- & $\begin{array}{c}0.066 \pm 0.022 \\
(\mathrm{~J})\end{array}$ & -- & -- & -- & $0.37 \pm 0.08$ \\
\hline MP1203 & $3-5$ & 130 & -- & -- & -- & -- & -- & -- \\
\hline MP1400 & $0-0.5$ & -- & -- & -- & $2.61 \pm 0.62$ & $\begin{array}{c}0.103 \pm \\
0.041\end{array}$ & -- & $0.29 \pm 0.08$ \\
\hline MP1401 & $1-3$ & 1,700 & -- & -- & $2.77 \pm 0.65$ & -- & -- & -- \\
\hline MP1499 & $0-0.5$ & -- & -- & -- & $2.55 \pm 0.64$ & -- & -- & -- \\
\hline MP1504 & $4-6$ & 5,300 & -- & -- & -- & -- & -- & -- \\
\hline MP1601 & $1-3$ & 3,300 & -- & -- & $\begin{array}{c}1.72 \pm 0.59 \\
(\mathrm{~J})\end{array}$ & -- & -- & -- \\
\hline MP1603 & $3-5$ & 200 & -- & -- & $1.95 \pm 0.58$ & -- & -- & -- \\
\hline MP1708 & $8-10$ & -- & -- & -- & $3.95 \pm 0.91$ & -- & -- & -- \\
\hline
\end{tabular}


Table 4-1

Sample Results for COCs at CAS 03-09-07

Used To Establish Current Use Restriction

(Page 2 of 2)

\begin{tabular}{|c|c|c|c|c|c|c|c|c|}
\hline \multirow{2}{*}{ Sample ID } & \multirow{2}{*}{$\begin{array}{c}\text { Depth } \\
\text { (ft bgs) }\end{array}$} & $\begin{array}{l}\text { TPH } \\
\text { (DRO) }\end{array}$ & TPH (GRO) & Am-241 & Eu-152 & U-235 & Pu-238 & Pu-239 \\
\hline & & $\begin{array}{c}\text { PAL } \\
100 \mathrm{mg} / \mathrm{kg}\end{array}$ & $\begin{array}{c}\text { PAL } \\
100 \mathrm{mg} / \mathrm{kg}\end{array}$ & $\begin{array}{c}\text { PAL } \\
0.05 \mathrm{pCi} / \mathrm{g}\end{array}$ & $\begin{array}{c}\text { PAL } \\
\text { Not } \\
\text { Identified }\end{array}$ & $\begin{array}{c}\text { PAL } \\
0.07 \mathrm{pCi} / \mathrm{g}\end{array}$ & $\begin{array}{c}\text { PAL } \\
0.05 \mathrm{pCi} / \mathrm{g}\end{array}$ & $\begin{array}{c}\text { PAL } \\
0.106 \mathrm{pCi} / \mathrm{g}\end{array}$ \\
\hline MP1711 & $11-13$ & -- & -- & -- & $2.85 \pm 0.63$ & -- & -- & -- \\
\hline MP1907 & $7-9$ & -- & -- & $0.96 \pm 0.39$ & -- & -- & -- & $0.19 \pm 0.055$ \\
\hline MP2004 & $4-6$ & -- & -- & -- & $1.75 \pm 0.52$ & -- & -- & -- \\
\hline
\end{tabular}

Am $=$ Americium

bgs $=$ Below ground surface

DRO = Diesel-range organics

$\mathrm{Eu}=$ Europium

$\mathrm{ft}=$ Foot

$\mathrm{GRO}=$ Gasoline-range organics

$\mathrm{ID}=$ Identification

$\mathrm{J}=$ Estimated value

-- = No detects above action levels $\mathrm{mg} / \mathrm{kg}=$ Milligrams per kilogram

$\mathrm{PAL}=$ Preliminary action level

$\mathrm{pCi} / \mathrm{g}=$ Picocuries per gram

$\mathrm{Pu}=$ Plutonium

$\mathrm{TPH}=$ Total petroleum hydrocarbons

$\mathrm{U}=$ Uranium

\subsection{Basis for Use Restriction Modification}

The revised FALs for radionuclides other than Eu-152 listed in Table 4-2 were established based on the PALs presented in Section 2.2.1. The revised FAL for Eu-152 was established based on a site-specific RESRAD calculation of a $25 \mathrm{mrem} / \mathrm{yr}$ dose under an industrial scenario (see Section 2.2.2) as prescribed in Industrial Sites Project Establishment of Final Action Levels (NNSA/NSO, 2006c).

The revised FALs associated with the TPH contamination were established based on the PALs of hazardous constituents of TPH diesel and TPH gasoline described in Section 2.2.2. Hazardous constituents of TPH diesel and TPH gasoline were not detected in any of the samples at concentrations greater than their respective PALs (DOE/NV, 2001a). Therefore, no contaminants are present at this site in concentrations exceeding the revised FALs. All revised FALs other than Eu-152 were established at the PAL concentrations.

Table 4-2 presents the sample results with the revised FALs and demonstrate that none exceed the revised FALs. 
Table 4-2

Revised Final Action Levels for CAS 03-09-07

\begin{tabular}{|c|c|c|c|c|c|c|}
\hline \multirow[b]{2}{*}{ Sample ID } & \multirow{2}{*}{$\begin{array}{l}\text { Depth } \\
\text { (ft bgs) }\end{array}$} & Am-241 & Eu-152 & U-235 & Pu-238 & Pu-239 \\
\hline & & $\begin{array}{c}\text { Revised FAL } \\
12.7 \mathrm{pCi} / \mathrm{g}\end{array}$ & $\begin{array}{c}\text { Revised FAL } \\
62.6 \mathrm{pCi} / \mathrm{g}\end{array}$ & $\begin{array}{c}\text { Revised FAL } \\
17.6 \mathrm{pCi} / \mathrm{g}\end{array}$ & $\begin{array}{l}\text { Revised FAL } \\
13 \mathrm{pCi} / \mathrm{g}\end{array}$ & $\begin{array}{c}\text { Revised FAL } \\
12.7 \mathrm{pCi} / \mathrm{g}\end{array}$ \\
\hline MP0108 & $8-10$ & -- & $1.25 \pm 0.48(\mathrm{~J})$ & -- & -- & -- \\
\hline MP0500 & $0-0.5$ & -- & $6.1 \pm 1.2$ & -- & -- & -- \\
\hline MP0600 & $0-1$ & $\begin{array}{c}0.212 \pm 0.066 \\
(\mathrm{~J})\end{array}$ & $1.97 \pm 0.48$ & $0.079 \pm 0.036$ & $0.193 \pm 0.053$ & $1.16 \pm 0.19$ \\
\hline MP0800 & $0-0.5$ & $2.00 \pm 0.72$ & -- & -- & -- & $0.43 \pm 0.09$ \\
\hline MP0900 & $0-1$ & $\begin{array}{c}0.125 \pm 0.032 \\
(\mathrm{~J})\end{array}$ & $1.26 \pm 0.45(\mathrm{~J})$ & $0.072 \pm 0.038$ & -- & $0.18 \pm 0.05$ \\
\hline MP1200 & $0-1$ & $\begin{array}{c}0.066 \pm 0.022 \\
(\mathrm{~J})\end{array}$ & -- & -- & -- & $0.37 \pm 0.08$ \\
\hline MP1400 & $0-0.5$ & -- & $2.61 \pm 0.62$ & $0.103 \pm 0.041$ & -- & $0.29 \pm 0.08$ \\
\hline MP1401 & $1-3$ & -- & $2.77 \pm 0.65$ & -- & -- & -- \\
\hline MP1499 & $0-0.5$ & -- & $2.55 \pm 0.64$ & -- & -- & -- \\
\hline MP1601 & $1-3$ & -- & $1.72 \pm 0.59(\mathrm{~J})$ & -- & -- & -- \\
\hline MP1603 & $3-5$ & -- & $1.95 \pm 0.58$ & -- & -- & -- \\
\hline MP1708 & $8-10$ & -- & $3.95 \pm 0.91$ & -- & -- & -- \\
\hline MP1711 & $11-13$ & -- & $2.85 \pm 0.63$ & -- & -- & -- \\
\hline MP1907 & $7-9$ & $0.96 \pm 0.39$ & -- & -- & -- & $0.19 \pm 0.055$ \\
\hline MP2004 & $4-6$ & -- & $1.75 \pm 0.52$ & -- & -- & -- \\
\hline
\end{tabular}

$\mathrm{Am}=$ Americium

bgs $=$ Below ground surface

$\mathrm{Eu}=$ Europium

$\mathrm{FAL}=$ Final action level

$\mathrm{ft}=$ Foot

$\mathrm{J}=$ Estimated value

-- = No detects above original action levels
ID = Identification

$\mathrm{pCi} / \mathrm{g}=$ Picocuries per gram

$\mathrm{Pu}=$ Plutonium

$\mathrm{U}=$ Uranium

\subsection{Proposed Modification}

Remove the FFACO UR and associated fencing and/or postings from this site. 


\subsection{CAU 214, CAS 25-23-01 - Contaminated Materials, and CAS 25-23-19 - Radioactive Material Storage}

\subsection{CAS Descriptions}

Corrective Action Sites 25-23-01 and 25-23-19 are adjacent to each other and have similar historical backgrounds. They are located west of and adjacent to the Yucca Mountain Project - Sample Management Facility. The CASs were used for storage of radioactive equipment, hazardous waste, heavy equipment, reactor components, and drums and tanks of unspecified materials from 1982 to 1992. In 1995, the majority of materials were removed from the yards. Material remaining at the site as of 2004 included a large amount of steel equipment, one large furnace, large pieces of concrete and steel associated with the MX missile program, and several pallets of miscellaneous housekeeping debris (NNSA/NSO, 2004c). During closure activities, miscellaneous wood and metal debris - including metal framing, wooden pallets, and a dishwasher - were removed and disposed of as construction debris as a best management practice (BMP). Items deemed too large to remove were left in place (NNSA/NSO, 2006a).

\subsection{Current Use Restriction Description}

The future use of any land affected by these URs is restricted from any DOE or Air Force activity that may alter or modify the containment control, as approved by the state and identified in the CAU CR or other CAU documentation, unless appropriate concurrence is obtained in advance. Site monitoring requirements for the UR include periodic visual inspections of UR postings and fencing. These are required annually for the first five years, followed by every five years, for a total of 30 years (NNSA/NSO, 2006a).

\subsection{Basis for Current Use Restriction}

Samples were analyzed for TPH (DRO and GRO), total VOCs, total SVOCs, total RCRA metals, total beryllium, PCBs, isotopic U, isotopic Pu, Sr-90, total pesticides, Toxicity Characteristic Leaching Procedure (TCLP) pesticides, total herbicides, TCLP herbicides, total chromium, hexavalent chromium, and gamma spectroscopy. Except for TPH-DRO, all other COPCs in the material remaining (following remediation) were detected below their PALs, including VOCs and SVOCs. Concentrations of TPH-DRO exceeding the PAL of $100 \mathrm{mg} / \mathrm{kg}$ were detected in 39 samples (NNSA/NSO, 2004c). 
Table 5-1 contains analytical results of all COCs at CASs 25-23-01 and 25-23-19 that are the basis for the current UR. The sample matrix for all samples is soil.

Table 5-1

Sample Results for COCs at CASs 25-23-01 and 25-23-19 Used To Establish Current Use Restriction

(Page 1 of 2)

\begin{tabular}{|c|c|c|c|c|}
\hline \multirow{2}{*}{ CAS } & \multirow{2}{*}{$\begin{array}{l}\text { Sample } \\
\text { Location }\end{array}$} & \multirow{2}{*}{$\begin{array}{c}\text { Sample } \\
\text { ID }\end{array}$} & \multirow{2}{*}{$\begin{array}{l}\text { Depth } \\
\text { (ft bgs) }\end{array}$} & \multirow{2}{*}{$\begin{array}{c}\text { TPH (DRO) } \\
\text { PAL } \\
100 \mathrm{mg} / \mathrm{kg}\end{array}$} \\
\hline & & & & \\
\hline \multirow{27}{*}{ 25-23-01 } & D01 & 214D002 & $0-0.5$ & $200(H, Z)$ \\
\hline & D02 & 214D041 & $0-0.5$ & $220(\mathrm{H}, \mathrm{Z})$ \\
\hline & D06 & 214D039 & $0-0.5$ & $130(\mathrm{H}, \mathrm{Z})$ \\
\hline & D07 & 214D009 & $0-0.5$ & $3,500(\mathrm{~J})$ \\
\hline & \multirow{2}{*}{ D10 } & 214D013 & $0-0.5$ & $2,800(\mathrm{H}, \mathrm{Z})$ \\
\hline & & 214D077 & $3.5-4.0$ & $200(Z)$ \\
\hline & D11 & 214D004 & $0-0.5$ & $170(\mathrm{H}, \mathrm{Z})$ \\
\hline & D12 & 214D006 & $0-0.5$ & $300(\mathrm{H}, \mathrm{Z})$ \\
\hline & D13 & 214D001 & $0-0.5$ & $280(\mathrm{H}, \mathrm{Z})$ \\
\hline & D14 & 214D012 & $0-0.5$ & $110(\mathrm{H}, \mathrm{Z})$ \\
\hline & D15 & 214D015 & $0-0.5$ & $250(\mathrm{H}, \mathrm{Z})$ \\
\hline & D16 & 214D040 & $0-0.5$ & $290(H, Z)$ \\
\hline & D17 & 214D014 & $0-0.5$ & $140(\mathrm{H}, \mathrm{Z})$ \\
\hline & D19 & 214D003 & $0-0.5$ & $180(\mathrm{H}, \mathrm{Z})$ \\
\hline & D20 & 214D018 & $0-0.5$ & $210(H, Z)$ \\
\hline & D21 & 214D005 & $0-0.5$ & $140(\mathrm{H}, \mathrm{Z})$ \\
\hline & D22 & 214D007 & $0-0.5$ & $290(H, Z)$ \\
\hline & D23 & 214D010 & $0-0.5$ & $290(H, Z)$ \\
\hline & D24 & 214D011 & $0-0.5$ & $110(\mathrm{H}, \mathrm{Z})$ \\
\hline & D25 & 214D043 & $0-0.5$ & $190(\mathrm{H}, \mathrm{Z})$ \\
\hline & D26 & 214D038 & $0-0.5$ & $230(\mathrm{H}, \mathrm{Z})$ \\
\hline & YO1 & 214Y001 & $0-0.5$ & $460(\mathrm{~J})$ \\
\hline & & 214Y002 & $0-0.5$ & $520(\mathrm{~J})$ \\
\hline & Y03 & 214Y005 & $0-0.5$ & $110(\mathrm{H}, \mathrm{M})$ \\
\hline & YOA & 214Y009 & $0-0.5$ & $240(\mathrm{H}, \mathrm{M})$ \\
\hline & & $214 Y 010$ & $0-0.5$ & $240(\mathrm{H}, \mathrm{M})$ \\
\hline & Y27 & 214Y034 & $0-0.5$ & $140(\mathrm{H}, \mathrm{M})$ \\
\hline
\end{tabular}


Table 5-1

Sample Results for COCs at CASs 25-23-01 and 25-23-19 Used To Establish Current Use Restriction

(Page 2 of 2)

\begin{tabular}{|c|c|c|c|c|}
\hline \multirow[b]{2}{*}{ CAS } & \multirow{2}{*}{$\begin{array}{l}\text { Sample } \\
\text { Location }\end{array}$} & \multirow{2}{*}{$\begin{array}{c}\text { Sample } \\
\text { ID }\end{array}$} & \multirow{2}{*}{$\begin{array}{l}\text { Depth } \\
\text { (ft bgs) }\end{array}$} & \multirow{2}{*}{$\begin{array}{c}\text { TPH (DRO) } \\
\text { PAL } \\
100 \mathrm{mg} / \mathrm{kg}\end{array}$} \\
\hline & & & & \\
\hline \multirow{3}{*}{ 25-23-01 } & & 214Y064 & 4.5 & $580(\mathrm{H}, \mathrm{M})$ \\
\hline & Y29 & 214Y042 & $0-0.5$ & $120(\mathrm{H}, \mathrm{M})$ \\
\hline & Y31 & 214Y044 & $0-0.5$ & $130(\mathrm{H}, \mathrm{M})$ \\
\hline \multirow{9}{*}{ 25-23-19 } & Y33 & 214Y046 & $0-0.5$ & $100(\mathrm{H}, \mathrm{M})$ \\
\hline & E01 & 214E010 & $0-0.5$ & $190(\mathrm{H}, \mathrm{Z})$ \\
\hline & E02 & 214E001 & $0-0.5$ & $290(H, Z)$ \\
\hline & E03 & 214E003 & $0-0.5$ & $150(\mathrm{H}, \mathrm{Z})$ \\
\hline & E04 & 214E005 & $0-0.5$ & $140(\mathrm{H}, \mathrm{Z})$ \\
\hline & E08 & 214E002 & $0-0.5$ & $270(\mathrm{H}, \mathrm{Z})$ \\
\hline & E09 & 214E006 & $0-0.5$ & $120(\mathrm{H}, \mathrm{Z})$ \\
\hline & E10 & 214E004 & $0-0.5$ & $140(\mathrm{H})$ \\
\hline & E12 & 214E011 & $0-0.5$ & $180(\mathrm{H}, \mathrm{Z})$ \\
\hline \multicolumn{2}{|c|}{$\begin{array}{l}\text { bgs = Below ground surface } \\
\text { DRO = Diesel-range organics } \\
\mathrm{ft}=\text { Foot } \\
\text { ID = Identification }\end{array}$} & & \multicolumn{2}{|c|}{$\begin{array}{l}\mathrm{mg} / \mathrm{kg}=\text { Milligrams per kilogram } \\
\mathrm{PAL}=\text { Preliminary action level } \\
\text { TPH = Total petroleum hydrocarbons }\end{array}$} \\
\hline \multicolumn{5}{|c|}{$\begin{array}{l}H=\text { The fuel pattern was in the heavier end of the retention time window for the analyte of interest. } \\
J=\text { Estimated value. } \\
M=\text { A pattern resembling motor fuel was detected. } \\
Z=\text { A significant fraction of the reported result did not resemble the patterns of the following petroleum } \\
\text { hydrocarbon products: gasoline, JP-4, JP-8, diesel, mineral spirits, motor oil, Stoddard Solvent, and } \\
\text { Bunker C. }\end{array}$} \\
\hline
\end{tabular}

\subsection{Basis for Use Restriction Modification}

The revised FALs associated with the TPH contamination were established based on the PALs of hazardous constituents of TPH diesel described in Section 2.2.2. Hazardous constituents of TPH diesel were not detected in any of the samples at concentrations greater than their respective PALs (NNSA/NSO, 2004c). Therefore, no contaminants are present at this site in concentrations exceeding the revised FALs, and all revised FALs were established at the PAL concentrations.

\subsection{Proposed Modification}

Remove the FFACO UR, associated fencing and postings, and inspection and maintenance requirements from these sites. 


\subsection{CAU 262, CAS 25-05-06 - Leachfield}

\subsection{CAS Description}

The Engine Maintenance, Assembly, and Disassembly (E-MAD) Facility Posted Leachfield System (CAS 25-05-06) received radioactive and process effluent from Building 3900 (E-MAD Building). The CAS consists of the leachfield, distribution box, and associated piping. The leachfield is located approximately $625 \mathrm{ft}$ southwest of Building 3900. Waste liquids generated by decontamination and chemical analysis of test units, and decontamination of personnel, equipment, and the facility were received by dedicated radioactive wastewater drains. The E-MAD Building, adjoining trailers, and the Train Decontamination Area pad components of the E-MAD Facility were connected to the posted leachfield through pipes or waste holdup tanks in a vault on the east side of the E-MAD Building (NNSA/NV, 2001a).

\subsection{Current Use Restriction Description}

The future use of any land related to this UR is restricted from any DOE or Air Force activity that may alter or modify the containment control, as approved by the state and identified in the CAU CR or other CAU documentation, unless appropriate concurrence is obtained in advance. The UR is defined by the 2.1-meter (m) (7-ft)-high security fence bounding the leachfield. An inspection will be performed annually and consist of visual observations to verify that the fence is in good condition, proper signs are in place and readable, and the UR is maintained (NNSA/NSO, 2003a).

\subsection{Basis for Current Use Restriction}

Samples from this CAS were analyzed for PCBs, total VOCs, total SVOCs, TPH Diesel/Oil, total RCRA metals, isotopic Pu, isotopic U, gamma spectroscopy, and Sr-90. Ten of 97 subsurface soil samples were contaminated with Sr-90 at concentrations exceeding the PAL. Of those 10 samples, two had cesium (Cs)-137 and U contamination exceeding PALs. The PALs for the radionuclides were established in the CAIP as any activity distinguishable from undisturbed background activity. No VOC, TPH, SVOC, or PCB analytical results exceeded PALs. All RCRA metals analytical results were below PALs, except arsenic, which was detected above the PAL of $2.7 \mathrm{mg} / \mathrm{kg}$ in 59 of the 94 samples. The concentrations of arsenic above the PAL of $2.7 \mathrm{mg} / \mathrm{kg}$ were within the range considered representative of ambient conditions at the site. Therefore, arsenic is not considered to be a basis for this UR (NNSA/NV, 2001a). 
Table 6-1 contains analytical results of all COCs at CAS 25-05-06 that are the basis for the current UR. The sample matrix for all samples is soil.

Table 6-1

Sample Results for COCs at CAS 25-05-06 Used To Establish Current Use Restriction

\begin{tabular}{|c|c|c|c|c|c|}
\hline \multirow{2}{*}{ Sample ID } & \multirow{2}{*}{$\begin{array}{l}\text { Depth } \\
\text { (ft bgs) }\end{array}$} & Cs-137 & $\mathrm{U}-234$ & U-235 & Sr-90 \\
\hline & & $\begin{array}{c}\text { PAL } \\
7 \mathrm{pCi} / \mathrm{g}\end{array}$ & $\begin{array}{c}\text { PAL } \\
1.56 \mathrm{pCi} / \mathrm{g}\end{array}$ & $\begin{array}{c}\text { PAL } \\
0.07 \mathrm{pCi} / \mathrm{g}\end{array}$ & $\begin{array}{c}\text { PAL } \\
1.17 \mathrm{pCi} / \mathrm{g}\end{array}$ \\
\hline EPR02B06 & $6.5-7.5$ & -- & -- & -- & $1.77 \pm 0.40$ \\
\hline EPR03B13 & $13.5-14.5$ & -- & -- & $0.08 \pm 0.030$ & -- \\
\hline EPR04A06 & $6-7$ & $44.5 \pm 5.7$ & $8.5 \pm 1.1$ & $0.42 \pm 0.081$ & $12.6 \pm 2.3$ \\
\hline EPR04A08 & $8.5-9.5$ & -- & $1.69 \pm 0.24$ & $0.108 \pm 0.034$ & -- \\
\hline EPR05A14 & $14-15$ & -- & -- & $0.08 \pm 0.03$ & -- \\
\hline EPR05A24 & $24-25$ & -- & -- & $0.093 \pm 0.035$ & -- \\
\hline EPR11A10 & $10-11$ & -- & -- & $0.085 \pm 0.031$ & -- \\
\hline EPR12A07 & $7.5-8.5$ & -- & -- & $0.102 \pm 0.035$ & -- \\
\hline EPR12A10 & $10-11$ & -- & -- & $0.109 \pm 0.039$ & $3.42 \pm 0.69$ \\
\hline EPR13A08 & $8-9$ & -- & $2.03 \pm 0.30$ & $0.112 \pm 0.036$ & $8.9 \pm 1.6$ \\
\hline EPR13A10 & $10.5-11.5$ & -- & -- & $0.083 \pm 0.030$ & $3.62 \pm 0.72$ \\
\hline EPR13A20 & $20.5-21.5$ & -- & -- & $0.104 \pm 0.034$ & -- \\
\hline EPR13A99 & $10.5-11.5$ & -- & -- & $0.101 \pm 0.033$ & $3.09 \pm 0.62$ \\
\hline EPR14A07 & $7.5-8.5$ & -- & $1.61 \pm 0.30$ & $0.115 \pm 0.052(\mathrm{~J})$ & $3.70 \pm 0.71$ \\
\hline EPR15A07 & $7.5-8.5$ & -- & -- & $0.084 \pm 0.039(\mathrm{~J})$ & -- \\
\hline EPR16A07 & $7.5-8.5$ & -- & -- & $0.09 \pm 0.039(\mathrm{~J})$ & $2.63 \pm 0.53$ \\
\hline EPR17A07 & $7.5-8.5$ & $11.9 \pm 1.5$ & -- & -- & $4.82 \pm 0.92$ \\
\hline EPR17A10 & $10-11$ & -- & -- & $0.129 \pm 0.047$ & $3.03 \pm 0.61$ \\
\hline EPR18A07 & $7-8$ & -- & -- & $0.091 \pm 0.041$ & -- \\
\hline EPR18A09 & $9.5-10.5$ & -- & -- & $0.087 \pm 0.037$ & -- \\
\hline EPR19A07 & $7-8$ & -- & -- & $0.087 \pm 0.041$ & -- \\
\hline EPR19A09 & $9.5-10.5$ & -- & -- & $0.073 \pm 0.036$ & -- \\
\hline EPR19A15 & $15-16$ & -- & -- & $0.071 \pm 0.035$ & -- \\
\hline EPR20A10 & $10-11$ & -- & -- & $0.073 \pm 0.040$ & -- \\
\hline EPR21A09 & $9.5-10.5$ & -- & -- & $0.081 \pm 0.041$ & -- \\
\hline EPR22A09 & $9.5-10.5$ & -- & -- & $0.07 \pm 0.035$ & -- \\
\hline EPR29A20 & $20-21$ & -- & -- & $0.073 \pm 0.026$ & -- \\
\hline
\end{tabular}

bgs $=$ Below ground surface

$\mathrm{Cs}=$ Cesium

$\mathrm{ft}=$ Foot

ID = Identification

$\mathrm{J}=$ Estimated value

-- $=$ No detects above action levels
$\mathrm{PAL}=$ Preliminary action level $\mathrm{pCi} / \mathrm{g}=$ Picocuries per gram $\mathrm{Sr}=$ Strontium $\mathrm{U}=$ Uranium 


\subsection{Basis for Use Restriction Modification}

The revised FALs for radionuclides other than Cs-137 as listed in Table 6-2 were established based on PALs presented in Section 2.2.1. The revised FAL for Cs-137 was established based on a site-specific RESRAD calculation of a $25 \mathrm{mrem} / \mathrm{yr}$ dose under an industrial scenario (see Section 2.2.2) as prescribed in Industrial Sites Project Establishment of Final Action Levels (NNSA/NSO, 2006c).

Therefore, no contaminants are present at this site in concentrations exceeding the revised FALs. All revised FALs other than Cs-137 were established at the PAL concentrations.

Table 6-2 presents the sample results that are the basis for the current UR and demonstrate that none exceed the revised FALs.

Table 6-2

Revised Final Action Levels for CAS 25-05-06

(Page 1 of 2)

\begin{tabular}{|c|c|c|c|c|c|}
\hline \multirow{2}{*}{$\begin{array}{l}\text { Sample } \\
\text { ID No. }\end{array}$} & \multirow{2}{*}{$\begin{array}{l}\text { Depth } \\
\text { (ft bgs) }\end{array}$} & Cs-137 & U-234 & $\mathrm{U}-235$ & Sr-90 \\
\hline & & $\begin{array}{c}\text { Revised FAL } \\
122 \mathrm{pCi} / \mathrm{g}\end{array}$ & $\begin{array}{l}\text { Revised FAL } \\
143 \mathrm{pCi} / \mathrm{g}\end{array}$ & $\begin{array}{c}\text { Revised FAL } \\
17.6 \mathrm{pCi} / \mathrm{g}\end{array}$ & $\begin{array}{c}\text { Revised FAL } \\
838 \mathrm{pCi} / \mathrm{g}\end{array}$ \\
\hline EPR02B06 & $6.5-7.5$ & -- & -- & -- & $1.77 \pm 0.40$ \\
\hline EPR03B13 & $13.5-14.5$ & -- & -- & $0.08 \pm 0.030$ & -- \\
\hline EPR04A06 & $6-7$ & $44.5 \pm 5.7$ & $8.5 \pm 1.1$ & $0.42 \pm 0.081$ & $12.6 \pm 2.3$ \\
\hline EPR04A08 & $8.5-9.5$ & -- & $1.69 \pm 0.24$ & $0.108 \pm 0.034$ & -- \\
\hline EPR05A14 & $14-15$ & -- & -- & $0.08 \pm 0.03$ & -- \\
\hline EPR05A24 & $24-25$ & -- & -- & $0.093 \pm 0.035$ & -- \\
\hline EPR11A10 & $10-11$ & -- & -- & $0.085 \pm 0.031$ & -- \\
\hline EPR12A07 & $7.5-8.5$ & -- & -- & $0.102 \pm 0.035$ & -- \\
\hline EPR12A10 & $10-11$ & -- & -- & $0.109 \pm 0.039$ & $3.42 \pm 0.69$ \\
\hline EPR13A08 & $8-9$ & -- & $2.03 \pm 0.30$ & $0.112 \pm 0.036$ & $8.9 \pm 1.6$ \\
\hline EPR13A10 & $10.5-11.5$ & -- & -- & $0.083 \pm 0.030$ & $3.62 \pm 0.72$ \\
\hline EPR13A20 & $20.5-21.5$ & -- & -- & $0.104 \pm 0.034$ & -- \\
\hline EPR13A99 & $10.5-11.5$ & -- & -- & $0.101 \pm 0.033$ & $3.09 \pm 0.62$ \\
\hline EPR14A07 & $7.5-8.5$ & -- & $1.61 \pm 0.30$ & $\begin{array}{c}0.115 \pm 0.052 \\
(\mathrm{~J})\end{array}$ & $3.70 \pm 0.71$ \\
\hline EPR15A07 & $7.5-8.5$ & -- & -- & $\begin{array}{c}0.084 \pm 0.039 \\
(\mathrm{~J})\end{array}$ & -- \\
\hline EPR16A07 & $7.5-8.5$ & -- & -- & $0.09 \pm 0.039(\mathrm{~J})$ & $2.63 \pm 0.53$ \\
\hline
\end{tabular}


Table 6-2

Revised Final Action Levels for CAS 25-05-06

(Page 2 of 2)

\begin{tabular}{||c|c|c|c|c|c||}
\hline \multirow{2}{*}{$\begin{array}{c}\text { Sample } \\
\text { ID }\end{array}$} & $\begin{array}{c}\text { Depth } \\
\mathbf{f t} \text { bgs })\end{array}$ & $\begin{array}{c}\text { Cs-137 } \\
\text { Revised FAL }\end{array}$ & $\begin{array}{c}\text { U-234 } \\
\text { Revised FAL } \\
\mathbf{1 4 3} \mathbf{~ p C i / g}\end{array}$ & $\begin{array}{c}\text { Revised FAL } \\
\mathbf{1 7 . 6} \text { pCi/g }\end{array}$ & $\begin{array}{c}\text { Revised FAL } \\
\mathbf{8 3 8} \text { pCi/g }\end{array}$ \\
\hline \hline EPR17A07 & $7.5-8.5$ & $11.9 \pm 1.5$ & -- & -- & $4.82 \pm 0.92$ \\
\hline EPR17A10 & $10-11$ & -- & -- & $0.129 \pm 0.047$ & $3.03 \pm 0.61$ \\
\hline EPR18A07 & $7-8$ & -- & -- & $0.091 \pm 0.041$ & -- \\
\hline EPR18A09 & $9.5-10.5$ & -- & -- & $0.087 \pm 0.037$ & -- \\
\hline EPR19A07 & $7-8$ & -- & -- & $0.087 \pm 0.041$ & -- \\
\hline EPR19A09 & $9.5-10.5$ & -- & -- & $0.073 \pm 0.036$ & -- \\
\hline EPR19A15 & $15-16$ & -- & -- & $0.071 \pm 0.035$ & -- \\
\hline EPR20A10 & $10-11$ & -- & -- & $0.081 \pm 0.041$ & - \\
\hline EPR21A09 & $9.5-10.5$ & -- & -- & $0.07 \pm 0.035$ & - \\
\hline EPR22A09 & $9.5-10.5$ & -- & $0.073 \pm 0.026$ & - \\
\hline EPR29A20 & $20-21$ & -- & -- \\
\hline
\end{tabular}

bgs $=$ Below ground surface

$\mathrm{Cs}=$ Cesium

$\mathrm{FAL}=$ Final action level

$\mathrm{ft}=$ Foot

$\mathrm{J}=$ Estimated value

-- = No detects above original action levels

\subsection{Proposed Modification}

Remove the FFACO UR, associated fencing and postings, and inspection and maintenance requirements from this site.
$\mathrm{pCi} / \mathrm{g}=$ Picocuries per gram

$\mathrm{Sr}=$ Strontium

$\mathrm{U}=$ Uranium 


\subsection{CAU 271, CAS 27-05-02 - Leachfield}

\subsection{CAS Description}

The septic system is located southwest of Building 5210 and west of Building 5200. The west side of the CAS 27-05-02 leachfield is bordered by a natural wash (i.e., arroyo). The septic system received effluent from restroom facilities including toilets, urinals, sinks, and floor drains inside Buildings 5210 and 5200. In addition, Building 5210 had a full kitchen with food preparation, dish washing, and cleanup operations. Building 5200 contained a service sink and an acid dip tank located beside a sink on a "solder bench." The septic system consisted of the influent lines from Buildings 5210 and 5200, a septic tank, a distribution structure, and a leachfield. The septic tank and distribution structure were removed as part of the corrective action. The remaining leachfield is approximately $80 \mathrm{ft}$ long by $24 \mathrm{ft}$ wide and consists of five 4-inch (in.), parallel orangeburg distribution lines. The lines are approximately $80 \mathrm{ft}$ long and spaced $6 \mathrm{ft}$ apart on center. The distribution lines are placed in 2-ft-wide trenches. A layer of approximately 18 in. of coarse gravel served as leachrock in each trench. The septic tank, manhole, and distribution box were removed (DOE/NV, 2001b).

\subsection{Current Use Restriction Description}

The future use of any land affected by this UR is restricted from any DOE or Air Force activity that may alter or modify the containment control as approved by the state and identified in the CAU CR or other CAU documentation unless appropriate concurrence is obtained in advance. The only remaining COCs associated with this CAS are confined to the leachfield. The UR was implemented for the leachfield to control inadvertent intrusion or exposure to the leachfield. Warning signs were installed at the four corners of the leachfield. An inspection will be performed annually and will consist of visual observations to verify that the proper signs are in place and readable, and the UR is maintained (NNSA/NSO, 2004a).

\subsection{Basis for Current Use Restriction}

Samples from this CAS were analyzed for VOCs, SVOCs, RCRA metals, TPH (DRO and GRO), and PCBs. The PALs were not exceeded in any of the soil samples from remaining materials (following remediation) except arsenic and PCBs.

Arsenic was detected above the PAL of $2.7 \mathrm{mg} / \mathrm{kg}$ in 50 percent of the samples analyzed. Arsenic was detected at concentrations up to $4.93 \mathrm{mg} / \mathrm{kg}$. Concentrations of arsenic are 
consistent in the leachfield soil and do not appear to represent locations of elevated radioactivity or evidence of a localized spill. Although arsenic concentrations in the soil exceed the PAL of $2.7 \mathrm{mg} / \mathrm{kg}$, these concentrations are believed to be within ambient conditions for CAS 27-05-02 and do not represent contamination. Therefore, arsenic is not considered to be a basis for this UR (NNSA/NSO, 2004d).

Elevated PCB concentrations were identified in the leachfield soil. Aroclor 1254 was detected at 7,600 micrograms per kilogram ( $\mu \mathrm{g} / \mathrm{kg}$ ) in one sample, exceeding the $1,000 \mu \mathrm{g} / \mathrm{kg}$ PAL.

Aroclor 1248 was detected in concentrations exceeding the 1,000 $\mu \mathrm{g} / \mathrm{kg}$ PAL, in 10 samples, at levels up to 22,000 $\mu \mathrm{g} / \mathrm{kg}$. The highest concentrations were detected in surface soil samples (NNSA/NSO, 2004d).

Table 7-1 contains analytical results of all COCs at CAS 27-05-02 that are the basis for the current UR. The sample matrix for all samples is soil.

Table 7-1

Sample Results for COCs at CAS 27-05-02 Used To Establish Current Use Restriction

\begin{tabular}{|c|c|c|c|}
\hline \multirow{2}{*}{ Sample ID } & \multirow{2}{*}{$\begin{array}{l}\text { Depth } \\
\text { (ft bgs) }\end{array}$} & Aroclor 1248 & \multirow{2}{*}{$\begin{array}{c}\text { Aroclor } 1254 \\
\text { PAL } \\
1,000 \mu \mathrm{g} / \mathrm{kg}\end{array}$} \\
\hline & & $\begin{array}{c}\text { PAL } \\
1,000 \mu \mathrm{g} / \mathrm{kg}\end{array}$ & \\
\hline $271 \mathrm{Q} 003$ & $5.2-6.2$ & 1,000 & -- \\
\hline 271Q203 & $5.5-6$ & 5,300 & $7,600(\mathrm{~J})$ \\
\hline 271Q208 & $0-0.5$ & 19,000 & -- \\
\hline 271Q224 & $0-1$ & 22,000 & -- \\
\hline 271Q225 & $2.5-3$ & 4,700 & -- \\
\hline 271Q228 & $0-0.5$ & 8,400 & -- \\
\hline 271Q229 & $2.5-3$ & 9,400 & -- \\
\hline 271Q230 & $2.5-3$ & 1,500 & -- \\
\hline 271Q231 & $5.5-6$ & 2,800 & -- \\
\hline 271Q232 & $8.5-9$ & 5,800 & -- \\
\hline \multicolumn{2}{|c|}{$\begin{array}{l}\text { bgs = Below ground surface } \\
\mathrm{ft}=\text { Foot } \\
\mathrm{ID}=\text { Identification } \\
\mathrm{PAL}=\text { Preliminary action level } \\
\mu \mathrm{g} / \mathrm{kg}=\text { Micrograms per kilogram }\end{array}$} & \multicolumn{2}{|c|}{$\begin{array}{l}\mathrm{J}=\text { Estimated value } \\
--=\text { No detects above action levels }\end{array}$} \\
\hline
\end{tabular}




\subsection{Basis for Use Restriction Modification}

The revised FALs for PCBs listed in Table 7-2 were established using the Tier 2-based FAL process presented in Section 2.2.2. These FALs were calculated using the Occasional Use Area site-specific exposure scenario. This scenario assumes that a worker will be exposed to the site contaminants for up to 400 total hours. This exposure scenario is for undeveloped sites, where there are no facilities, where an industrial worker would normally be assigned (NNSA/NSO, 2006c). Because CAS 27-05-02 is located in a remote area of the NTS (Area 27), no current or foreseeable future activities would cause any worker to be exposed to this site for a period of time exceeding that assumed in the Occasional Use Area site-specific scenario (i.e., 400 total hours). However, these undeveloped areas may be used for military type exercises where it is assumed that a worker could be exposed for a period of up to 80 hours per year for five years.

The UR modification would be to implement an administrative UR as described in Section 2.0. This administrative UR would restrict any activity that would result in any worker being within the UR boundary for a lifetime-duration of more than 400 total hours.

Table 7-2 presents the sample results that are the basis for the current UR and demonstrate that none exceed the revised FALs (based on an Occasional Use Area land-use scenario).

Table 7-2

Revised Final Action Levels for CAS 27-05-02 (Page 1 of 2)

\begin{tabular}{||c|c|c|c||}
\hline \multirow{2}{*}{ Sample ID } & \multirow{2}{*}{$\begin{array}{c}\text { Depth } \\
\mathbf{f t} \mathbf{b g s})\end{array}$} & $\begin{array}{c}\text { Aroclor 1248 } \\
\text { Revised FAL } \\
\mathbf{5 9 , 1 0 0} \boldsymbol{\mu g} / \mathbf{k g}\end{array}$ & $\begin{array}{c}\text { Aroclor 1254 } \\
\mathbf{4 9 , 1 0 0} \boldsymbol{\mu g} \mathbf{~} \mathbf{k g}\end{array}$ \\
\hline \hline $271 \mathrm{Q} 003$ & $5.2-6.2$ & 1,000 & -- \\
\hline $271 \mathrm{Q} 203$ & $5.5-6$ & 5,300 & $7,600(\mathrm{~J})$ \\
\hline $271 \mathrm{Q} 208$ & $0-0.5$ & 19,000 & -- \\
\hline $271 \mathrm{Q} 224$ & $0-1$ & 22,000 & -- \\
\hline $271 \mathrm{Q} 225$ & $2.5-3$ & 4,700 & -- \\
\hline $271 \mathrm{Q} 228$ & $0-0.5$ & 8,400 & -- \\
\hline $271 \mathrm{Q} 229$ & $2.5-3$ & 9,400 & -- \\
\hline $271 \mathrm{Q} 230$ & $2.5-3$ & 1,500 & -- \\
\hline $271 \mathrm{Q} 231$ & $5.5-6$ & 2,800 & -- \\
\hline
\end{tabular}


Table 7-2

Revised Final Action Levels for CAS 27-05-02

(Page 2 of 2)

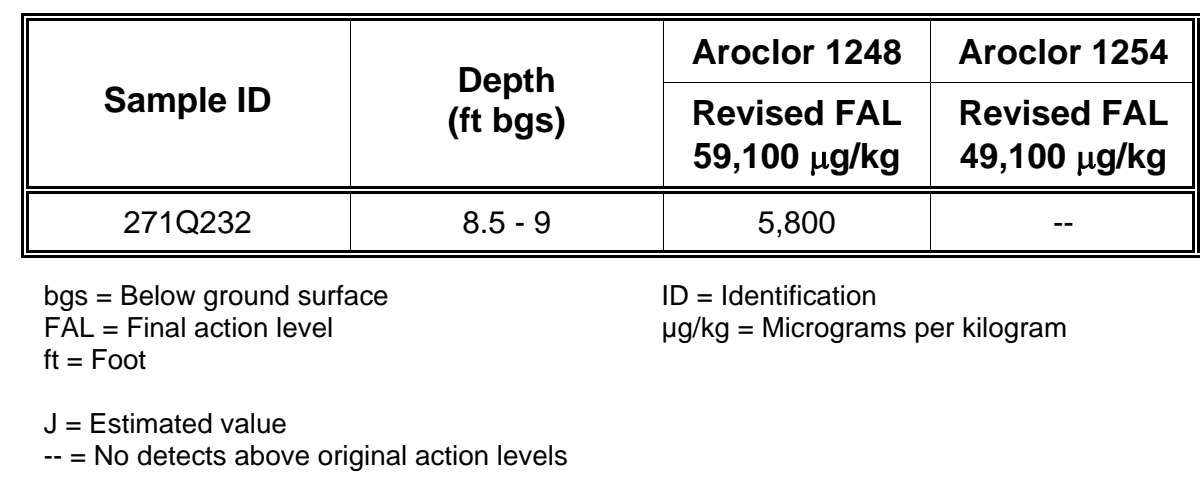

\subsection{Proposed Modification}

Implement an administrative UR as described in Section 2.0 restricting any activity that would result in any worker being within the UR boundary for a lifetime-duration of more than 400 total hours. Remove all associated fencing and postings and discontinue inspection and maintenance at this site. 


\subsection{CAU 321, CAS 22-99-05 - Fuel Storage Area}

\subsection{CAS Description}

Corrective Action Site 22-99-05 is the only CAS within CAU 321, located in Area 22 of the NTS. The Fuel Storage Area was used to store fuel and other petroleum products necessary for motorized operations at the historic Camp Desert Rock facility, which was operational from 1951 to 1958. The Fuel Storage Area was dismantled after 1958 (NNSA/NV, 2001b).

The Fuel Storage Area was identified as a potential oil spill site. A 1955 aerial photograph shows two rectangular tanks and other items stored within the bermed Fuel Storage Area. The site has one relatively small area where slightly discolored soil has been observed. Otherwise, there is no visible staining, odor, or vegetative stress observed within the Fuel Storage Area (NNSA/NV, 2001b).

\subsection{Current Use Restriction Description}

The future use of any land related to this UR, as defined by the 150-square-foot $\left(\mathrm{ft}^{2}\right)$ area, located in the southeast corner of CAU 321, is restricted from any DOE or Air Force activity that may alter or modify the containment control, as approved by the state and identified in the CAU CR or other CAU documentation, unless appropriate concurrence is obtained in advance. There are no monitoring requirements associated with this UR (NNSA/NV, 2001b).

\subsection{Basis for Current Use Restriction}

Samples were analyzed for VOCs, SVOCs, TPH-gasoline, TPH-diesel, and total lead. Samples analyzed for TPH (DRO) at 11 to $12 \mathrm{ft}$ below ground surface (bgs), and 16 to $17 \mathrm{ft}$ bgs from sample location 32100E during the January/February 2001 investigation, had concentrations of $220 \mathrm{mg} / \mathrm{kg}$ and $170 \mathrm{mg} / \mathrm{kg}$, respectively. These concentrations exceeded the PAL of $100 \mathrm{mg} / \mathrm{kg}$. No VOCs or SVOCs were detected above PALs. No radiological analyses were conducted because all the field survey results were within background levels. No other contaminants were identified above PALs at the site (NNSA/NV, 2001b).

Table 8-1 contains analytical results of all COCs at CAS 22-99-05 that are the basis for the current UR. The sample matrix for all samples is soil. 
Table 8-1

Sample Results for COCs at CAS 22-99-05

Used To Establish Current Use Restriction

\begin{tabular}{|c|c|c|c|}
\hline \multirow[b]{2}{*}{ Investigation } & \multirow[b]{2}{*}{ Sample ID } & \multirow{2}{*}{$\begin{array}{l}\text { Depth } \\
\text { (ft bgs) }\end{array}$} & \multirow{2}{*}{$\begin{array}{c}\text { TPH (DRO) } \\
\text { PAL } \\
100 \mathrm{mg} / \mathrm{kg}\end{array}$} \\
\hline & & & \\
\hline \multirow{2}{*}{ January/February 2001} & 32100E11 & $11-12$ & 220 \\
\hline & 32100E16 & $16-17$ & 170 \\
\hline $\begin{array}{l}\text { bgs = Below ground surface } \\
\text { DRO = Diesel-range organics } \\
\mathrm{ft}=\text { Foot } \\
\text { ID = Identification }\end{array}$ & & $\begin{array}{l}=\text { Milligrams } \\
\text { Preliminary } \\
\text { Total petrole }\end{array}$ & \\
\hline
\end{tabular}

\subsection{Basis for Use Restriction Modification}

The revised FALs associated with the TPH contamination were established based on the PALs of hazardous constituents of TPH diesel as described in Section 2.2.2. Hazardous constituents of TPH diesel were not detected in any of the samples at concentrations greater than their respective PALs (NNSA/NV, 2001b). Therefore, no contaminants are present at this site in concentrations exceeding the revised FALs, and all revised FALs were established at the PAL concentrations.

\subsection{Proposed Modification}

Remove the FFACO UR and associated fencing and postings from this CAS. 


\subsection{CAU 322, CAS 01-25-01 - AST Release}

\subsection{CAS Description}

The former aboveground storage tank (AST) is located in Area 1, within the boundaries of the Shaker Plant, in the northern portion of plant grounds. The AST was located within a berm constructed of earth and gravel, and the berm floor contains several pieces of large wooden plyboard used for tank support. Additional pieces of heavy railroad ties were discovered under the berm floor surface during excavation. The berm once contained a 10,000-gal diesel fuel AST, which was relocated approximately $40 \mathrm{ft}$ southeast of the CAS. The AST provided fuel for the operation of the Shaker Plant (NNSA/NSO, 2004e).

\subsection{Current Use Restriction Description}

The future use of any land affected by this UR is restricted from any DOE or Air Force activity that may alter or modify the containment control, as approved by the state and identified in the CAU CR or other CAU documentation, unless appropriate concurrence is obtained in advance. As part of closure activities, fencing was erected around the rectangular AST berm to limit access to the interior of the berm, and four UR signs were posted around the perimeter of the berm. Site monitoring requirements for the UR include periodic visual inspections of UR postings and fencing. These are required annually for the first five years, followed by every five years, for a total of 30 years (NNSA/NSO, 2006b).

\subsection{Basis for Current Use Restriction}

Samples were analyzed for TPH (DRO and GRO), total VOCs, total SVOCs, total RCRA metals, total beryllium, PCBs, and gamma spectroscopy. Except for TPH-DRO, all other COPCs were detected below their PALs, including VOCs and SVOCs. Concentrations of TPH-DRO exceeding the PAL of $100 \mathrm{mg} / \mathrm{kg}$ were detected at both sampling locations (NNSA/NSO, 2004e).

Table 9-1 contains analytical results of all COCs at CAS 01-25-01 that are the basis for the current UR. The sample matrix for all samples is soil. 
Table 9-1

Sample Results for COCs at CAS 01-25-01

Used To Establish Current Use Restriction

\begin{tabular}{|c|c|c|c|}
\hline \multirow{2}{*}{$\begin{array}{l}\text { Sample } \\
\text { Location }\end{array}$} & \multirow[b]{2}{*}{ Sample ID } & \multirow{2}{*}{$\begin{array}{c}\text { Depth } \\
\text { (ft bgs) }\end{array}$} & TPH (DRO) \\
\hline & & & $\begin{array}{c}\text { PAL } \\
100 \mathrm{mg} / \mathrm{kg}\end{array}$ \\
\hline \multirow{2}{*}{ A01 } & 322A001 & $0-0.5$ & $2,900(\mathrm{~J})$ \\
\hline & 322A002 & $2-3$ & 480 (D) \\
\hline \multirow{6}{*}{ A02 } & $322 \mathrm{~A} 003$ & $0-0.5$ & $5,900(\mathrm{~J})$ \\
\hline & 322A004 & $2-3$ & $7,000(\mathrm{~J})$ \\
\hline & $322 A 005$ & $2-3$ & 6,900 (D) \\
\hline & 322A009 & $4-5$ & $6,700(\mathrm{D})$ \\
\hline & $322 \mathrm{~A} 010$ & $6-7$ & $1,100(\mathrm{D})$ \\
\hline & 322A011 & $9-10$ & 140 (D) \\
\hline
\end{tabular}

bgs = Below ground surface

DRO $=$ Diesel-range organics

$\mathrm{mg} / \mathrm{kg}=$ Milligrams per kilogram

$\mathrm{PAL}=$ Preliminary action level

$\mathrm{ft}=$ Foot

$\mathrm{TPH}=$ Total petroleum hydrocarbons

$\mathrm{D}=\mathrm{A}$ pattern resembling diesel was detected in the samples.

$\mathrm{J}=$ Estimated value

\subsection{Basis for Use Restriction Modification}

The revised FALs associated with the TPH contamination were established based on the PALs of hazardous constituents of TPH diesel as described in Section 2.2.2. Hazardous constituents of TPH diesel were not detected in any of the samples at concentrations greater than their respective PALs (NNSA/NSO, 2004e). Therefore, no contaminants are present at this site in concentrations exceeding the revised FALs, and all revised FALs were established at the PAL concentrations.

\subsection{Proposed Modification}

Remove the FFACO UR, associated fencing and postings, and inspection and maintenance requirements from this site. 


\subsection{CAU 322, CAS 03-25-03 - Mud Plant AST Diesel Release}

\subsection{CAS Description}

Corrective Action Site 03-25-03 is located within the former Mud Plant facility in the former Area 3 Camp. The Mud Plant facility began operation in February 1962 and was used to formulate mud mixtures in support of drilling operations for the UGTA Project. The Mud Plant facility operations ceased in December 1995. An AST containing fuel oil and a fuel dispensing station were located approximately $350 \mathrm{ft}$ west of the Mud Plant. Available records indicated the AST had a capacity of approximately 10,000 gal and was located in a gravel containment pit. Aerial photos indicate the fuel dispensing station was located south of the AST. Information was not available regarding the type of equipment or physical condition of the fuel dispensing station. The AST and fuel station were removed; however, the date of the removal is not available (NNSA/NSO, 2003f).

\subsection{Current Use Restriction Description}

The future use of any land affected by this UR is restricted from any DOE or Air Force activity that may alter or modify the containment control, as approved by the state and identified in the CAU CR or other CAU documentation, unless appropriate concurrence is obtained in advance. As part of closure activities, fencing was erected along the Mud Plant boundary, connecting with existing fencing surrounding the Mud Plant Pond and Mud Disposal Crater to limit access to the interior of the contaminated area, and six UR signs were installed around the impacted area between the Mud Plant, Mud Plant Pond, and Mud Disposal Crater. Site monitoring requirements for the UR include periodic visual inspections of UR postings and fencing. These are required annually for the first five years, followed by every five years, for a total of 30 years. (NNSA/NSO, 2006b)

\subsection{Basis for Current Use Restriction}

Samples were analyzed for TPH (DRO and GRO), total VOCs, total SVOCs, total RCRA metals, PCBs, total beryllium, isotopic $\mathrm{U}$, isotopic $\mathrm{Pu}, \mathrm{Sr}-90$, and gamma spectroscopy. Except for TPH-DRO, all other COPCs were detected below their PALs, including VOCs and SVOCs. Concentrations of TPH-DRO exceeding the PAL of $100 \mathrm{mg} / \mathrm{kg}$ were detected at six sampling locations (NNSA/NSO, 2004e). 
Table 10-1 contains analytical results of all COCs at CAS 03-25-03 that are the basis for the current UR. The sample matrix for all samples is soil.

Table 10-1

Sample Results for COCs at CAS 03-25-03

Used To Establish Current Use Restriction

\begin{tabular}{|c|c|c|c|c|}
\hline \multirow{2}{*}{$\begin{array}{c}\text { Sample } \\
\text { Location }\end{array}$} & \multirow[b]{2}{*}{ Area } & \multirow[b]{2}{*}{ Sample ID } & \multirow{2}{*}{$\begin{array}{l}\text { Depth } \\
\text { (ft bgs) }\end{array}$} & TPH (DRO) \\
\hline & & & & $\begin{array}{c}\text { PAL } \\
100 \mathrm{mg} / \mathrm{kg}\end{array}$ \\
\hline B01 & \multirow{2}{*}{ A } & 322B038 & $2-3$ & $140(\mathrm{D}, \mathrm{H}, \mathrm{M})$ \\
\hline B04 & & 322B010 & $0-0.5$ & $370(\mathrm{H}, \mathrm{M})$ \\
\hline B08 & \multirow{5}{*}{ B } & 322B053 & $2-3$ & $170(\mathrm{H}, \mathrm{M})$ \\
\hline B14 & & 322B043 & $14-15$ & $300(H, Y)$ \\
\hline \multirow{2}{*}{ B15 } & & 322B020 & $0-0.5$ & $150(\mathrm{H}, \mathrm{M})$ \\
\hline & & 322B044 & $2-3$ & $4,000(Y)$ \\
\hline B17 & & 322B062 & $2-3$ & $1,500(\mathrm{H}, \mathrm{M})$ \\
\hline
\end{tabular}

bgs $=$ Below ground surface

DRO $=$ Diesel-range organics

$\mathrm{mg} / \mathrm{kg}=$ Milligrams per kilogram

$\mathrm{ft}=$ Foot

$\mathrm{PAL}=$ Preliminary action level

ID = Identification

$\mathrm{TPH}=$ Total petroleum hydrocarbons

$\mathrm{D}=\mathrm{A}$ pattern resembling diesel was detected in the samples.

$\mathrm{H}=$ The fuel pattern was in the heavier end of the retention time window for the analyte of interest.

$M=A$ pattern resembling motor oil was detected.

$\mathrm{Y}=$ Multipeak chromatogram does not match target analytes.

\subsection{Basis for Use Restriction Modification}

The revised FALs associated with the TPH contamination were established based on the PALs of hazardous constituents of TPH diesel described in Section 2.2.2. Hazardous constituents of TPH diesel were not detected in any of the samples at concentrations greater than their respective PALs (NNSA/NSO, 2004e). Therefore, no contaminants are present at this site in concentrations exceeding the revised FALs, and all revised FALs were established at the PAL concentrations.

\subsection{Proposed Modification}

Remove the FFACO UR, associated fencing and postings, and inspection and maintenance requirements from this site. 


\subsection{CAU 335, CAS 06-20-02 - 20-inch Cased Hole}

\subsection{CAS Description}

The Cased Hole is approximately $10 \mathrm{ft}$ from the northeast corner of Building 6-388 in the southern portion of the Well 3 Yard. The site was used for the disposal of used motor oil, wastewater, and debris. On October 2, 1990, the Cased Hole was inspected by Reynolds Electrical \& Engineering Co., Inc., and noted to be a 20-in. diameter steel casing that rises approximately $2 \mathrm{ft}$ above grade. Used motor oil, wastewater, and solid debris were removed from the casing (DOE/NV, 2000c).

The casing was excavated with a backhoe on July 25, 1991. During excavation, the surface soil surrounding the casing was noted to be contaminated. The Cased Hole was then backfilled, though it is unknown when this occurred or what material was used for backfill. The site is currently described as a 5-ft-diameter, 3-in.-high mound of soil, presumably at the former location of the Cased Hole (DOE/NV, 2000c).

\subsection{Current Use Restriction Description}

The future use of any land related to this CAS is restricted from any DOE or Air Force activity that may alter or modify the containment control, as approved by the state and identified in the CAU CR or other CAU documentation, unless appropriate concurrence is obtained in advance. The UR covers two land areas: (1) a large area south of Road 6-06, and (2) a small area immediately north of Road 6-06. T-posts with attached warning signs were placed along the perimeter of the areas approximately every $100 \mathrm{ft}$. All signs warn of the presence of TPH-contaminated soil and lists contact information. Post-closure monitoring consists of an annual sign inspection to verify that they are in place and readable, and that URs are maintained (NNSA/NSO, 2003b).

\subsection{Basis for Current Use Restriction}

Samples were analyzed for total VOCs, total SVOCs, TPH (DRO), and total RCRA metals. Except for arsenic, TPH (DRO) was the only COPC detected above PALs in the remaining material (following remediation). Arsenic was detected above the PAL of $2.7 \mathrm{mg} / \mathrm{kg}$ in all 12 samples taken at Cased Hole. The concentrations of arsenic above the PAL of $2.7 \mathrm{mg} / \mathrm{kg}$ were within the range considered representative of ambient conditions at the site. Therefore, arsenic is not considered to be a basis for this UR. Total petroleum hydrocarbons (DRO) were 
detected at concentrations exceeding the PAL of $100 \mathrm{mg} / \mathrm{kg}$ in 16 of 93 soil samples collected at this CAS. The vertical extent of TPH (DRO) contamination did not exceed $0.5 \mathrm{ft}$ bgs except for three anomalous sample locations at the Cased Hole where TPH was found at up to $5 \mathrm{ft}$ bgs. The lateral extent of TPH (DRO) contamination at the Cased Hole was generally confined to the north by Road 6-06, to the east by the Mercury Highway, and to the west by the boundaries of the drilling supply storage area. No VOCs or SVOCs were detected above PALs (NNSA/NV, 2001c).

Table 11-1 contains analytical results of all COCs at CAS 06-20-02 that are the basis for the current UR. The sample matrix for all samples is soil.

Table 11-1

Sample Results for COCs at CAS 06-20-02 Used To Establish Current Use Restriction

\begin{tabular}{|c|c|c|c|c|}
\hline \multirow[b]{2}{*}{ Investigation } & \multirow[b]{2}{*}{ Sample Location } & \multirow[b]{2}{*}{ Sample ID } & \multirow{2}{*}{$\begin{array}{l}\text { Depth } \\
\text { (ft bgs) }\end{array}$} & \multirow{2}{*}{$\begin{array}{c}\text { TPH (DRO) } \\
\text { PAL } \\
100 \mathrm{mg} / \mathrm{kg} \\
\end{array}$} \\
\hline & & & & \\
\hline \multirow{3}{*}{ January 2001} & $\begin{array}{l}\text { Boring } \mathrm{CHO} \text { (former } \\
\text { location of steel casing }\end{array}$ & $\mathrm{CH} 0101$ & $0.0-0.5$ & 1,100 \\
\hline & Boring $\mathrm{CHO} 2$ & $\mathrm{CH} 0202$ & $3-5$ & $180(\mathrm{~J})$ \\
\hline & Boring $\mathrm{CHO} 3$ & $\mathrm{CH} 0301$ & $0.0-0.5$ & $840(\mathrm{~J})$ \\
\hline \multirow{13}{*}{ May 2001} & \multirow{2}{*}{ Auger CHNO1 } & CHN01A & $0.0-0.5$ & 450 \\
\hline & & CHN01X & $0.0-0.5$ & 480 \\
\hline & Auger $\mathrm{CHNO2}$ & $\mathrm{CHN} 02 \mathrm{~A}$ & $0.0-0.5$ & 170 \\
\hline & Auger CHSO2 & $\mathrm{CHS02A}$ & $0.0-0.5$ & 490 \\
\hline & Auger CHE01 & CHE01A & $0.0-0.5$ & 580 \\
\hline & Auger CHE04 & CHE04A & $0.0-0.5$ & 140 \\
\hline & \multirow{2}{*}{ Auger CHWO2 } & CHW02A & $0.0-0.5$ & 1,700 \\
\hline & & CHW02B & $0.5-2$ & 120 \\
\hline & \multirow{2}{*}{ Auger CHW03 } & CHW03A & $0.0-0.5$ & $110(\mathrm{~J})$ \\
\hline & & CHW03X & $0.0-0.5$ & 110 \\
\hline & \multirow{3}{*}{ Auger CHWO4 } & CHW04A & $0.0-0.5$ & $3,100(\mathrm{~J})$ \\
\hline & & CHW04C & $2-3$ & 690 \\
\hline & & CHW04D & $3-4$ & 250 \\
\hline
\end{tabular}

bgs $=$ Below ground surface

$\mathrm{DRO}=$ Diesel-range organics

$\mathrm{mg} / \mathrm{kg}=$ Milligrams per kilogram

$\mathrm{ft}=$ Foot

PAL = Preliminary action level

ID = Identification

$\mathrm{TPH}=$ Total petroleum hydrocarbons

$\mathrm{J}=$ Estimated value 


\subsection{Basis for Use Restriction Modification}

The revised FALs associated with the TPH contamination were established based on the PALs of hazardous constituents of TPH diesel as described in Section 2.2.2. Hazardous constituents of $\mathrm{TPH}$ diesel were not detected in any of the samples at concentrations greater than their respective PALs (NNSA/NV, 2001c). Therefore, no contaminants are present at this site in concentrations exceeding the revised FALs, and all revised FALs were established at the PAL concentrations.

\subsection{Proposed Modification}

Remove the FFACO UR, associated fencing and postings, and inspection and maintenance requirements from this site. 


\subsection{CAU 335, CAS 06-23-03 - Drain Pit}

\subsection{CAS Description}

The Drain Pit is located in the northern section of the Well 3 Yard, approximately $165 \mathrm{ft}$ north of Road 6-06. It was used to receive effluent from truck washing facilities in the Well 3 Yard. The Drain Pit was operational from 1963 through about 1991, a time span roughly concurrent with underground device testing at the NTS. Cement trucks and geophysical logging trucks were washed in the Well 3 Yard, using two portable steam cleaners. The Drain Pit is oblong-shaped and measures 37 by $65 \mathrm{ft}$ with a maximum depth of about $6 \mathrm{ft}$ at its southeast end. Three drain pipes extend from the north wall of the pit: a pair of 2.5-in.-diameter steel pipes, and a single 5-in.-diameter plastic pipe (DOE/NV, 2000c).

\subsection{Current Use Restriction Description}

The future use of any land related to this CAS is restricted from any DOE or Air Force activity that may alter or modify the containment control, as approved by the state and identified in the CAU CR or other CAU documentation, unless appropriate concurrence is obtained in advance. T-posts with attached warning signs were placed every $100 \mathrm{ft}$ along the perimeter of the area identified in the NDEP-approved CADD (NNSA/NV, 2001c). All signs warn of the presence of TPH contaminated soil, list contact information, and face out away from the restricted area. Warning signs were placed at the four corners and at the midpoint of each side of the area. Post-closure monitoring consists of annual visual inspection of the signs to verify that they are in place and readable, and that URs are maintained (NNSA/NSO, 2003b).

\subsection{Basis for Current Use Restriction}

Samples were analyzed for total VOCs, total SVOCs, TPH (DRO), total RCRA metals, TPH (GRO), ethylene glycol monobutyl ether, PCBs, isotopic $\mathrm{U}$, isotopic Pu, and Sr-90. Total petroleum hydrocarbons (DRO) and arsenic were the only COPCs detected above PALs. Arsenic was detected above the PAL of $2.7 \mathrm{mg} / \mathrm{kg}$ in 27 of 27 samples. The concentrations of arsenic above the PAL of $2.7 \mathrm{mg} / \mathrm{kg}$ were within the range considered representative of ambient conditions at the site. Therefore, arsenic is not considered to be a basis for this UR. Total petroleum hydrocarbons (DRO) were detected at concentrations exceeding the PAL of $100 \mathrm{mg} / \mathrm{kg}$ in 16 of 50 soil samples collected from the Drain Pit. The vertical extent of TPH (DRO) contamination did not exceed $2 \mathrm{ft}$ bgs. The lateral extent of TPH (DRO) contamination at the Drain Pit investigation area was generally confined to the east by the Birdwell Building, to 
the west by a large concrete pad, and to the south by Road 6-06. Contamination was not found north of the Drain Pit. No VOCs or SVOCs were detected above PALs (NNSA/NV, 2001c).

Table 12-1 contains analytical results of all COCs at CAS 06-23-03 that are the basis for the current UR. The sample matrix for all samples is soil.

Table 12-1

Sample Results for COCs at CAS 06-23-03 Used To Establish Current Use Restriction

\begin{tabular}{|c|c|c|c|c|}
\hline \multirow{2}{*}{ Investigation } & \multirow{2}{*}{ Sample Location } & \multirow{2}{*}{ Sample ID } & \multirow{2}{*}{$\begin{array}{l}\text { Depth } \\
\text { (ft bgs) }\end{array}$} & \multirow{2}{*}{$\begin{array}{c}\text { TPH (DRO) } \\
\text { PAL } \\
100 \mathrm{mg} / \mathrm{kg}\end{array}$} \\
\hline & & & & \\
\hline \multirow{11}{*}{ January 2001} & Boring DP02 (Outside Drain Pit) & DP0202 & $0.5-2$ & 660 \\
\hline & Boring DP03 (Outside Drain Pit) & DP0302 & $0.5-2$ & 360 \\
\hline & Boring DP04 (Outside Drain Pit) & DP0402 & $0.5-2$ & 120 \\
\hline & Boring DP05 (Outside Drain Pit) & DP0502 & $0.5-2$ & 230 \\
\hline & Boring DP06 (Outside Drain Pit) & DP0602 & $0.5-2$ & 180 \\
\hline & \multirow{2}{*}{ Boring DP07 (Inside Drain Pit) } & DP0701 & $0.0-0.5$ & 650 \\
\hline & & DP0702 & $0.5-2$ & 450 \\
\hline & \multirow{2}{*}{ Boring DP08 (Inside Drain Pit) } & DP0801 & $0.0-0.5$ & 670 \\
\hline & & DP0802 & $0.5-2$ & 380 \\
\hline & \multirow{2}{*}{ Boring DP09 (Inside Drain Pit) } & DP0901 & $0.0-0.5$ & 430 \\
\hline & & DP0902 & $0.5-2$ & 580 \\
\hline \multirow{5}{*}{ May 2001} & Auger DPS01 & DPS01A & $0.0-0.5$ & 130 \\
\hline & Auger DPS04 & DPS04A & $0.0-0.5$ & 150 \\
\hline & Auger DPE01 & DPE01A & $0.0-0.5$ & 150 \\
\hline & Auger DPE03 & DPE03A & $0.0-0.5$ & 120 \\
\hline & Auger DPW02 & DPW02A & $0.75-1$ & 470 \\
\hline $\begin{array}{l}\text { bgs = Below groun } \\
\text { DRO = Diesel-rang } \\
\mathrm{ft}=\text { Foot }\end{array}$ & $\begin{array}{l}\text { Irface } \\
\text { rganics }\end{array}$ & $\begin{array}{l}=\text { Milligrams } \mathrm{p} \\
\text { Preliminary ac } \\
=\text { Total petroleu }\end{array}$ & $\begin{array}{l}\text { am } \\
\text { el } \\
\text { carbons }\end{array}$ & \\
\hline
\end{tabular}

ID = Identification 


\subsection{Basis for Use Restriction Modification}

The revised FALs associated with the TPH contamination were established based on the PALs of hazardous constituents of TPH diesel as described in Section 2.2.2. Hazardous constituents of TPH diesel were not detected in any of the samples at concentrations greater than their respective PALs (NNSA/NV, 2001c). Therefore, no contaminants are present at this site in concentrations exceeding the revised FALs, and all revised FALs were established at the PAL concentrations.

\subsection{Proposed Modification}

Remove the FFACO UR, associated fencing and postings, and inspection and maintenance requirements from this site. 


\subsection{CAU 342, CAS 23-56-01 - Former Mercury Fire Training Pit}

\subsection{CAS Description}

The Former Mercury Fire Training Pit (FTP) is located in Area 23 of the NTS on the west side of the Mercury Bypass Road and was used between approximately 1965 and 1990 to train firefighting personnel. It encompasses an area approximately 85 by $115 \mathrm{~m}$ (280 by $380 \mathrm{ft}$ ). The FTP formerly included a bermed burn pit with four small burn tanks; four large aboveground storage tanks (ASTs); an overturned bus; a telephone pole storage area; and areas for burning sheds, pallets, and cables. Training events involved burning fuels including off-specification or rust-contaminated gasoline; diesel; aviation fuel (JP-4); and other materials such as paint, tires, a pond liner, wood, paper, cloth, and copper cable (DOE/NV, 2000a).

\subsection{Current Use Restriction Description}

The future use of any land related to this CAS is restricted from any DOE or Air Force activity that may alter or modify the containment control, as approved by the state and identified in the CAU CR or other CAU documentation, unless appropriate concurrence is obtained in advance. A perimeter fence with warning signs encompasses the former Mercury FTP area (approximately 85 by $115 \mathrm{~m}$ [280 by $380 \mathrm{ft}$ ]). The defined plume is limited vertically to $50 \mathrm{ft}$. Site monitoring requirements include biannual visual inspection (DOE/NV, 2000a).

The CR states that the Post-Closure Plan also includes monitoring of soil gas vapor, to be performed initially within six months of completing field activities to establish baseline concentrations, and then every two years to determine whether natural attenuation is degrading the remaining petroleum hydrocarbons (DOE/NV, 2000a). Soil gas samples were collected on November 29, 2005, for VOC and SVOC analysis. Samples were collected on December 1, 2005, for analysis of base gases. The effectiveness of natural attenuation was evaluated and noted to be occurring. It was recommended that monitoring be discontinued (NNSA/NSO, 2006d) and on August 28, 2006, NDEP acknowledged and approved the decision to discontinue soil monitoring (Elle, 2006).

\subsection{Basis for Current Use Restriction}

Samples were analyzed for total and leachable VOCs, total SVOCs, total and leachable RCRA metals and zinc, TPH, PCBs, and gamma spectroscopy. Samples collected from locations where physical evidence or site history indicated burning (e.g., cable racks, charcoal stains, and burn 
sheds) were analyzed for dioxins and furans. Petroleum hydrocarbons, xylene, and arsenic were the only COPCs detected above PALs. Petroleum hydrocarbons (diesel, gasoline, waste oil, and unknown hydrocarbons) were detected above the PAL of $100 \mathrm{mg} / \mathrm{kg}$ in 37 samples. Of these, 33 were taken from the AST area and the CAS 23-56-01 burn pit. The VOC xylene was detected above the PAL of $320 \mathrm{mg} / \mathrm{kg}$ in one sample from the area of highest TPH contamination in the AST subsurface plume. The concentrations of arsenic above the PAL of $2.7 \mathrm{mg} / \mathrm{kg}$ were within the range considered representative of ambient conditions at the site. Therefore, arsenic is not considered to be a basis for this UR (DOE/NV, 1999c).

Table 13-1 contains analytical results of all COCs at CAS 23-56-01 that are the basis for the current UR. The sample matrix for all samples is soil.

Table 13-1

Sample Results for COCs at CAS 23-56-01 Used To Establish Current Use Restriction (Page 1 of 2)

\begin{tabular}{|c|c|c|c|c|c|c|}
\hline \multirow{2}{*}{ Sample ID } & \multirow{2}{*}{$\begin{array}{l}\text { Depth } \\
\text { (ft bgs) }\end{array}$} & Xylene & Diesel & Waste Oil & Gasoline & $\begin{array}{l}\text { Unknown } \\
\text { Hydrocarbon }\end{array}$ \\
\hline & & $\begin{array}{c}\text { PAL } \\
320 \mathrm{mg} / \mathrm{kg}\end{array}$ & $\begin{array}{c}\text { PAL } \\
100 \mathrm{mg} / \mathrm{kg}\end{array}$ & $\begin{array}{c}\text { PAL } \\
100 \mathrm{mg} / \mathrm{kg}\end{array}$ & $\begin{array}{c}\mathrm{PAL} \\
100 \mathrm{mg} / \mathrm{kg}\end{array}$ & $\begin{array}{c}\text { PAL } \\
100 \mathrm{mg} / \mathrm{kg}\end{array}$ \\
\hline FTP00020 & $0-1$ & -- & -- & -- & -- & 440 \\
\hline FTP00021 & $3-4$ & -- & -- & -- & -- & 420 \\
\hline FTP00022 & $0-1$ & -- & -- & -- & -- & 130 \\
\hline FTP00025 & $3-4$ & -- & -- & -- & -- & 100 \\
\hline FTP00026 & $0-1$ & -- & -- & -- & -- & 230 \\
\hline FTP00027 & $3-4$ & -- & -- & -- & -- & 420 \\
\hline FTP00028 & $0-1$ & -- & -- & -- & -- & 180 \\
\hline FTP00029 & $3-4$ & -- & -- & -- & -- & 370 \\
\hline FTP00034 & $0-1$ & -- & -- & -- & -- & 210 \\
\hline FTP00035 & $3-4$ & -- & -- & -- & -- & 590 \\
\hline FTP00036 & $0-1$ & -- & -- & -- & -- & 760 \\
\hline FTP00048 & $0-1$ & -- & 250 & -- & -- & -- \\
\hline FTP00049 & $3-4$ & -- & -- & -- & -- & 3,000 \\
\hline FTP00055 & $0-1$ & -- & -- & -- & -- & 4,000 \\
\hline FTP00056 & $3-4$ & -- & 2,800 & -- & -- & -- \\
\hline FTP00057 & $0-1$ & -- & -- & -- & -- & 410 \\
\hline
\end{tabular}


Table 13-1

Sample Results for COCs at CAS 23-56-01

Used To Establish Current Use Restriction

(Page 2 of 2)

\begin{tabular}{|c|c|c|c|c|c|c|}
\hline \multirow{2}{*}{ Sample ID } & \multirow{2}{*}{$\begin{array}{l}\text { Depth } \\
\text { (ft bgs) }\end{array}$} & Xylene & Diesel & Waste Oil & Gasoline & $\begin{array}{c}\text { Unknown } \\
\text { Hydrocarbon }\end{array}$ \\
\hline & & $\begin{array}{c}\text { PAL } \\
320 \mathrm{mg} / \mathrm{kg}\end{array}$ & $\begin{array}{c}\text { PAL } \\
100 \mathrm{mg} / \mathrm{kg}\end{array}$ & $\begin{array}{c}\text { PAL } \\
100 \mathrm{mg} / \mathrm{kg}\end{array}$ & $\begin{array}{c}\text { PAL } \\
100 \mathrm{mg} / \mathrm{kg}\end{array}$ & $\begin{array}{c}\text { PAL } \\
100 \mathrm{mg} / \mathrm{kg}\end{array}$ \\
\hline FTP00058 & $3-4$ & -- & 2,500 & -- & -- & -- \\
\hline FTP00062 & $0-1$ & -- & -- & 1,400 & -- & -- \\
\hline FTP00086 & $0-1$ & -- & -- & -- & -- & 4,000 \\
\hline FTP00089 & $0-1$ & -- & $4,100(\mathrm{~J})$ & -- & -- & -- \\
\hline FTP00091 & $4-5$ & -- & $3,400(\mathrm{~J})$ & -- & -- & -- \\
\hline FTP00094 & $19-20$ & -- & $10,000(\mathrm{~J})$ & -- & -- & -- \\
\hline FTP00108 & $14-15$ & -- & -- & 230 & -- & -- \\
\hline FTP00109 & $19-20$ & -- & 140 & -- & -- & -- \\
\hline FTP00111 & $4-5$ & -- & -- & -- & -- & 3,300 \\
\hline FTP00112 & $9-10$ & -- & -- & -- & -- & 10,000 \\
\hline FTP00128 & $9-10$ & -- & $16,000(\mathrm{~J})$ & -- & 530 & -- \\
\hline FTP00133 & $9-10$ & -- & $13,000(\mathrm{~J})$ & -- & -- & -- \\
\hline FTP00136 & $14-15$ & -- & $7,600(\mathrm{~J})$ & -- & -- & -- \\
\hline FTP00145 & $19-20$ & -- & $3,000(\mathrm{~J})$ & -- & -- & -- \\
\hline FTP00149 & $19-20$ & -- & $7,500(\mathrm{~J})$ & -- & -- & -- \\
\hline FTP00154 & $24-25$ & $480(\mathrm{~J})$ & $18,000(\mathrm{~J})$ & -- & $3,000(\mathrm{~J})$ & -- \\
\hline FTP00160 & $18.5-19$ & -- & $5,400(\mathrm{~J})$ & -- & $320(\mathrm{~J})$ & -- \\
\hline
\end{tabular}

bgs $=$ Below ground surface

$\mathrm{ft}=$ Foot

$\mathrm{J}=$ Estimated value

-- = No detects above action levels

= Identification

$\mathrm{mg} / \mathrm{kg}=$ Milligrams per kilogram

$\mathrm{PAL}=$ Preliminary action level

\subsection{Basis for Use Restriction Modification}

The revised FALs associated with the TPH contamination were established based on the hazardous constituents of TPH as described in Section 2.2.2. The only TPH-related contaminant detected above the corresponding PAL (DOE/NV, 1999c) was xylene. This constituent was evaluated per the Tier 2 evaluation process as described in Section 2.2.2. Under a Tier 2 evaluation, comparisons to action levels are only conducted at reasonable points of exposure. The single sample with a concentration exceeding the PAL was collected from a depth of 24 to $25 \mathrm{ft}$ bgs. As this depth is not a reasonable point of exposure, it was not evaluated. No other 
instances of xylene contamination exist at the CAS at concentrations that exceed the PAL. Therefore, no contaminants are considered to be present at this site in concentrations exceeding the revised FALs, and all revised FALs were established at the PAL concentrations.

\subsection{Proposed Modification}

Remove the FFACO UR, associated fencing and postings, and inspection and maintenance requirements from this site. 


\subsection{CAU 355, Area 2 Cellars/Mud Pits}

\subsection{CAS Descriptions}

Corrective Action Unit 355 is comprised of the following 15 CASs located in Area 2 of the NTS:

- CAS 02-37-01, Cellar \& Mud Pit

- CAS 02-37-03, Cellar \& Mud Pit

- CAS 02-37-04, Cellar \& Mud Pit

- CAS 02-37-05, Cellar \& Mud Pit

- CAS 02-37-06, Cellar \& Mud Pit

- CAS 02-37-07, Cellar \& Mud Pit

- CAS 02-37-10, Cellar \& Mud Pit

- CAS 02-37-11, Cellar \& Mud Pit

- CAS 02-37-12, Cellar \& Mud Pit

- CAS 02-37-13, Cellar \& Mud Pit

- CAS 02-37-14, Cellar \& Mud Pit

- CAS 02-37-15, Cellar \& Mud Pit

- CAS 02-37-16, Cellar \& Mud Pit

- CAS 02-37-17, Cellar

- CAS 02-37-18, Cellar \& Tanks

Historical documentation and interviews indicate that the cellars and associated mud pits in CAU 355 were constructed to support post-test drillback activities at sites where underground nuclear testing was conducted from 1967 through 1990. Post-test boreholes were drilled to re-enter the test cavities to determine cavity and chimney size, to observe the effects of the test on the surrounding material, determine the distribution of radioactivity in the area, and collect samples for analysis. During the drilling process, drilling mud was used for cooling and lubrication, and to carry the drill cuttings to the surface where they were deposited in a nearby mud pit (NNSA/NSO, 2003g).

Corrective Action Site 02-37-01 consists of a backfilled cellar within fencing that measures 13 by $13 \mathrm{ft}$ and an open mud pit that measures 16 by $59 \mathrm{ft}$ in total area. The mud pit is fenced and posted as an Underground Radioactive Material Area (URMA). The borehole casing has been plugged with cement and the cellar backfilled with soil/gravel (NNSA/NSO, 2003g).

Corrective Action Site 02-37-03 consists of a backfilled cellar and a backfilled mud pit inside a fence. The fence measures 26 by $128 \mathrm{ft}$ and is posted as an URMA. The borehole casing has been plugged with cement and the cellar backfilled with soil/gravel (NNSA/NSO, 2003g). 
Corrective Action Site 02-37-04 consists of a backfilled cellar and backfilled mud pit located inside a fence that is posted as an URMA. The total fenced area measures 20 by $128 \mathrm{ft}$. The borehole casing has been plugged with cement and the cellar backfilled with soil/gravel (NNSA/NSO, 2003g).

Corrective Action Site 02-37-05 consists of a backfilled cellar inside a fence that is posted as an URMA and measures 16 by $59 \mathrm{ft}$. The open mud pit measures 141 by $151 \mathrm{ft}$ and contains gray drilling mud residue and large amounts of drill cuttings. The borehole casing has been plugged with cement and the cellar backfilled with soil/gravel (NNSA/NSO, 2003g).

Corrective Action Site 02-37-06 consists of a cellar that has been backfilled and is located inside a fence. The open mud pit measures 50 by $75 \mathrm{ft}$ and is inside a fence that is posted as an URMA. The borehole casing was plugged with cement and the cellar backfilled with soil/gravel in 1994 (NNSA/NSO, 2003g).

Corrective Action Site 02-37-07 consists of a backfilled cellar and open mud pit located inside a fence that is posted as an URMA. The mud pit measures 27 by $66 \mathrm{ft}$. The borehole casing was plugged with cement and the cellar backfilled with soil/gravel in 1981 (NNSA/NSO, 2003g).

Corrective Action Site 02-37-10 consists of a backfilled cellar and backfilled mud pit inside a fence that measures approximately 26 by $151 \mathrm{ft}$ and is posted as an URMA. The borehole casing was plugged with cement and the cellar backfilled with soil/gravel in 1970 (NNSA/NSO, 2003g).

Corrective Action Site 02-37-11 consists of a backfilled cellar and backfilled mud pit inside a fence. The fence measures 36 by $141 \mathrm{ft}$ and is posted as an URMA. The borehole casing was plugged with cement and the cellar backfilled with soil/gravel in 1971 (NNSA/NSO, 2003g).

Corrective Action Site 02-37-12 consists of a backfilled cellar and backfilled mud pit located inside a fence. The fence measures 67 by $118 \mathrm{ft}$ and is posted as an URMA. The borehole casing was plugged with cement and the cellar backfilled soil/gravel in 1973 (NNSA/NSO, 2003g). 
Corrective Action Site 02-37-13 consists of a backfilled cellar and backfilled mud pit located inside a fence. The fence measures $67 \mathrm{by} 118 \mathrm{ft}$ and is posted as an URMA (NNSA/NSO, 2003g).

Corrective Action Site 02-37-14 consists of a backfilled cellar and an open mud pit located inside a fence measuring approximately 60 by $90 \mathrm{ft}$ and is posted as an URMA. The borehole casing was plugged with cement and the cellar was backfilled with soil/gravel in 1972 (NNSA/NSO, 2003g).

Corrective Action Site 02-37-15 consists of a backfilled cellar and backfilled mud pit located in a fence measuring 50 by $157 \mathrm{ft}$ and is posted as an URMA. The borehole casing was plugged with cement and the cellar backfilled with soil/gravel in 1972 (NNSA/NSO, 2003g).

Corrective Action Site 02-37-16 consists of a backfilled cellar and backfilled mud pit located inside a fence measuring 20 by $85 \mathrm{ft}$, and is posted as an URMA. The post-test borehole was plugged with cement and the cellar backfilled with soil/gravel in 1976 (NNSA/NSO, 2003g).

Corrective Action Site 02-37-17 consists of an open cellar measuring $8 \mathrm{ft}$ in diameter and is approximately $10 \mathrm{ft}$ deep. The cellar contains dark, moist soil and organic material; suspected drilling mud, and is located inside a fence that is posted as an URMA. It is a post-test cellar that is currently open (i.e., not backfilled). This cellar is associated with a post-test borehole that is identified to be plugged and abandoned by the Borehole Management Program (NNSA/NSO, 2003g).

Corrective Action Site 02-37-18 consists of an open cellar measuring $8 \mathrm{ft}$ in diameter and $14 \mathrm{ft}$ deep and an associated open mud pit not mentioned in the FFACO CAS description. The tanks mentioned in the CAS description have been removed from the site. The cellar is located inside a fence that is posted as an URMA, and contains dark, moist soil and organic material, and suspected drilling mud. The mud pit measures 59 by $125 \mathrm{ft}$, with one side of the pit partially backfilled, and contains wood and plastic piping debris. The cellar was completed as a gas sampling hole in 1990. It is a post-test cellar that is currently open (i.e., not backfilled). This cellar is associated with a post-test borehole that is identified to be plugged and abandoned by the Borehole Management Program (NNSA/NSO, 2003g). 


\subsection{Current Use Restriction Description}

The future use of any land affected by all URs in this CAU is restricted from any DOE or Air Force activity that may alter or modify the containment control, as approved by the state and identified in the CAU CR or other CAU documentation, unless appropriate concurrence is obtained in advance (NNSA/NSO, 2003c).

The UR boundary points for CASs $02-37-01,02-37-14$, and $02-37-16$ are at the corners of the fences posted for demarcation of the URMA. There are no site monitoring requirements (NNSA/NSO, 2003c).

The UR boundary points for CASs 02-37-03, 02-37-04, 02-37-05, 02-37-06, 02-37-07, 02-37-10, 02-37-11, 02-37-12, 02-37-17, and 02-37-18 are the cellar concrete pad corners. There are no site monitoring requirements (NNSA/NSO, 2003c).

The UR boundary points for CASs 02-37-13 and 02-37-15 are the cellar facility demarcation fence corners. There are no site monitoring requirements (NNSA/NSO, 2003c).

\subsection{Basis for Current Use Restriction}

All of the 15 CASs included a post-test drillback cellar. Thirteen of the post-test cellars were previously backfilled with clean fill material. Two of the post-test cellars at CASs 02-37-17 and 02-37-18 were open (i.e., not backfilled). In addition, 14 of the CASs included an associated drilling mud pit, with eight of these mud pits previously backfilled with clean fill, and the remaining six left open (i.e., not backfilled) (NNSA/NSO, 2003c).

Characterization samples were collected from the base of the two open cellars, the approximate base of the 13 backfilled cellars, and from drilling mud in the 14 mud pits. Samples were analyzed for VOCs, SVOCs, RCRA metals, TPH (full scan), PCBs, and gamma spectroscopy. Petroleum hydrocarbons (diesel, oil, and TPH) were detected above the PAL of $100 \mathrm{mg} / \mathrm{kg}$ for samples collected from the two open cellars (CASs 02-37-17 and 02-37-18), three backfilled cellars (CASs 02-37-11, 02-37-15, and 02-37-16), and from three of the mud pits (CASs 02-37-01, 02-37-14, and 02-37-16). Total petroleum hydrocarbons were the only COC detected at concentrations above action levels in any of the characterization samples collected, no VOCs or SVOCs were detected above PALs (NNSA/NSO, 2003c).

Based on the characterization sample results for the open post-test cellars and process knowledge of the historical decontamination of drilling equipment over the post-test cellars, it is reasonable 
to assume that TPH is present at the base of the backfilled post-test cellars at concentrations exceeding the action level. For this reason, URs were implemented at all 15 post-test cellars in CAU 355 (NNSA/NSO, 2003c).

Table 14-1 contains analytical results of all COCs at CAU 355 that are the basis for the current URs. The sample matrix for all samples is soil.

Table 14-1

Sample Results for COCs at CAU 355 Used To Establish Current Use Restriction

\begin{tabular}{||c|c|c|c||}
\hline \multirow{2}{*}{ Sample ID } & Diesel & Oil & TPH \\
\cline { 2 - 4 } & $\begin{array}{c}\text { PAL } \\
\mathbf{1 0 0} \mathbf{~ m g} / \mathbf{k g}\end{array}$ & $\begin{array}{c}\mathbf{P A L} \\
\mathbf{1 0 0} \mathbf{~} \mathbf{g} / \mathbf{k g}\end{array}$ & $\begin{array}{c}\mathbf{P A L} \\
\mathbf{1 0 0} \mathbf{~} \mathbf{g} / \mathbf{k g}\end{array}$ \\
\hline \hline $\begin{array}{c}\text { 01-01-M0 } \\
\text { Dup. of 01-01-M1 }\end{array}$ & 120 & 1,200 & 1,320 \\
\hline 01-01-M1 & 120 & 920 & 1,040 \\
\hline $11-(0-12)-C 1$ & -- & 160 & 160 \\
\hline $14-0-M 2$ & -- & 110 & 110 \\
\hline $15-(0-7)-C 1$ & -- & 140 & 140 \\
\hline $16-7-M 1$ & -- & 1,200 & 1,200 \\
\hline $16-6-C 1$ & 390 & 140 & 530 \\
\hline $17-10-C 1$ & 260 & 1,600 & 1,860 \\
\hline $18-14-C 1$ & 350 & 7,500 & 7,850 \\
\hline \hline
\end{tabular}

ID = Identification

$\mathrm{mg} / \mathrm{kg}=$ Milligrams per kilogram

$\mathrm{PAL}=$ Preliminary action level

$\mathrm{TPH}=$ Total petroleum hydrocarbons

$--=$ No detects above action levels

\subsection{Basis for Use Restriction Modification}

The revised FALs associated with the TPH contamination were established based on the PALs of the hazardous constituents of TPH as described in Section 2.2.2. Because the URs were implemented at all 15 post-test cellars in CAU 355, based on the characterization sample results for the open post-test cellars, and the fact that the samples with the maximum concentrations of TPH have no TPH-related contaminant concentrations above their corresponding PALs, it is reasonable to assume that no contaminants are present at this site in concentrations exceeding PALs, and the revised FALs were established at the PAL concentrations (NNSA/NSO, 2003c).

\subsection{Proposed Modification}

Remove the FFACO UR and associated fencing and postings from this site. 


\subsection{CAU 356, CAS 03-04-01 - Area 3 Change House Septic System}

\subsection{CAS Description}

The Area 3 Change House Septic System consists of a dual-chambered, steel septic tank; a concrete manhole south of the septic tank; two leachfields (referred to as the "previous leachfield" and the "fenced leachfield"); a concrete skimmer box at the proximal end of the fenced leachfield; and associated piping both upstream and downstream of the septic tank. The system was initially constructed in the 1960s and received effluent from at least nine Area 3 Camp buildings and trailers until its abandonment in 1991. In 1989, an unpermitted lagoon formed above the fenced leachfield as a consequence of excessive flow and saturated conditions. A new septic system was proposed, but not implemented due to the impending relocation of the Area 3 Camp to Area 6. Temporary remediation of the existing system consisted of evacuating the septic tank of fluids to be treated at other NTS facilities until the camp was abandoned. The temporary remediation efforts resulted in no additional percolation of effluent above ground surface (NNSA/NV, 2002a).

\subsection{Current Use Restriction Description}

The future use of any land affected by this UR is restricted from any DOE or Air Force activity that may alter or modify the containment control, as approved by the state and identified in the CAU CR or other CAU documentation, unless appropriate concurrence is obtained in advance. Orange snow fencing was installed around the 100-by-75-ft perimeter of the fenced leachfield. Use restriction signs were posted on permanent posts/poles on each side of the fenced leachfield. There is no annual monitoring or inspection requirements associated with the UR (NNSA/NV, 2002a).

\subsection{Basis for Current Use Restriction}

Twenty-three soil samples were collected and analyzed for VOCs, SVOCs, RCRA metals, TPH (DRO and GRO), isotopic Pu, isotopic U, isotopic Am, and gamma spectrometry. One analytical result indicated the presence of TPH (DRO) (400 mg/kg) contamination exceeding the NDEP action level of $100 \mathrm{mg} / \mathrm{kg}$ at one location. No VOCs or SVOCs were detected above PALs. Arsenic was detected above the PAL of $2.7 \mathrm{mg} / \mathrm{kg}$ in all samples analyzed, but all concentrations were within the range considered representative of ambient conditions at the site. Therefore, arsenic is not considered to be a basis for this UR. The radionuclides Am-241, $\mathrm{Pu}-238$, and Pu-239/240 exceeded their respective PALs. The PALs for the radionuclides were 
established in the CAIP as any activity distinguishable from undisturbed background activity (NNSA/NV, 2002a).

Table 15-1 contains analytical results of all COCs that are the basis for the current UR. The sample matrix for all samples is soil.

Table 15-1

Sample Results for COCs at CAS 03-04-01 Used To Establish Current Use Restriction

\begin{tabular}{|c|c|c|c|c|c|}
\hline \multirow{2}{*}{ Sample ID } & \multirow{2}{*}{$\begin{array}{l}\text { Depth } \\
\text { (ft bgs) }\end{array}$} & Pu-238 & Pu-239/240 & Am-241 & TPH (DRO) \\
\hline & & $\begin{array}{c}\text { PAL } \\
0.05 \mathrm{pCi} / \mathrm{g}\end{array}$ & $\begin{array}{c}\text { PAL } \\
0.106 \mathrm{pCi} / \mathrm{g}\end{array}$ & $\begin{array}{c}\text { PAL } \\
0.05 \mathrm{pCi} / \mathrm{g}\end{array}$ & $\begin{array}{c}\text { PAL } \\
100 \mathrm{mg} / \mathrm{kg}\end{array}$ \\
\hline 356003 & $5.0-5.5$ & -- & $0.485 \pm 0.14(\mathrm{~J})$ & $0.639 \pm 0.20$ & -- \\
\hline 356005 & $5.25-5.75$ & -- & -- & $2.44 \pm 0.38$ & -- \\
\hline 356012 & $0.0-0.5$ & -- & -- & -- & $400(\mathrm{~J})$ \\
\hline 356013 & $0.0-0.5$ & -- & -- & $1.76 \pm 0.41(\mathrm{~J})$ & -- \\
\hline 356016 & $4.0-4.5$ & -- & -- & $4.08 \pm 0.53(\mathrm{~J})$ & -- \\
\hline 356095 & $5.0-5.5$ & -- & $0.435 \pm 0.12(\mathrm{~J})$ & $3.64 \pm 1.8$ & -- \\
\hline 356204 & $0.0-0.5$ & $0.049 \pm 0.026$ & $0.211 \pm 0.058$ & -- & -- \\
\hline 356205 & $0.0-0.5$ & -- & $0.226 \pm 0.058$ & $0.053 \pm 0.027$ & -- \\
\hline 356207 & $0.0-0.5$ & $0.117 \pm 0.042$ & $1.38 \pm 0.23$ & $0.173 \pm 0.052$ & -- \\
\hline 356209 & $0.0-0.5$ & $0.469 \pm 0.094$ & $16.5 \pm 2.3$ & $2.23 \pm 0.34$ & -- \\
\hline
\end{tabular}

$\mathrm{Am}=$ Americium

bgs $=$ Below ground surface

$\mathrm{DRO}=$ Diesel-range organics

$\mathrm{ft}=$ Foot

$\mathrm{mg} / \mathrm{kg}=$ Milligrams per kilogram

$\mathrm{J}=$ Estimated value

-- = No detects above action levels
ID = Identification

$\mathrm{PAL}=$ Preliminary action level $\mathrm{pCi} / \mathrm{g}=$ Picocuries per gram

$\mathrm{Pu}=$ Plutonium

$\mathrm{TPH}=$ Total petroleum hydrocarbons

\subsection{Basis for Use Restriction Modification}

The revised FALs for radionuclides listed in Table 12-2 were established based on the PALs presented in Section 2.2.1.

The revised FALs associated with the TPH contamination were established based on the PALs of hazardous constituents of TPH diesel as described in Section 2.2.2. Hazardous constituents of TPH diesel were not detected in any of the samples at concentrations greater than their respective PALs (NNSA/NV, 2002a). 
Therefore, no contaminants are present at this site in concentrations exceeding the revised FALs, and all revised FALs were established at the PAL concentrations.

Table 15-2 presents the sample results that are the basis for the current UR was based and demonstrate that none exceed the revised FALs.

Table 15-2

Revised Final Action Levels for CAS 03-04-01

\begin{tabular}{||c|c|c|c|c||}
\hline \multirow{2}{*}{ Sample ID } & $\begin{array}{c}\text { Depth } \\
\text { (ft bgs) }\end{array}$ & $\begin{array}{c}\text { Pu-238 } \\
\text { 13 pCi/g }\end{array}$ & $\begin{array}{c}\text { Pu-239/240 } \\
\mathbf{1 2 . 7} \text { pCi/g }\end{array}$ & $\begin{array}{c}\text { Am-241 } \\
\mathbf{1 2 . 7} \text { pCi/g }\end{array}$ \\
\cline { 3 - 5 } & $5.0-5.5$ & -- & $0.485 \pm 0.14(\mathrm{~J})$ & $0.639 \pm 0.20$ \\
\hline \hline 356003 & $5.25-5.75$ & -- & -- & $2.44 \pm 0.38$ \\
\hline 356005 & $0.0-0.5$ & -- & -- & $1.76 \pm 0.41(\mathrm{~J})$ \\
\hline 356013 & $4.0-4.5$ & -- & -- & $4.08 \pm 0.53(\mathrm{~J})$ \\
\hline 356016 & $5.0-5.5$ & -- & $0.435 \pm 0.12(\mathrm{~J})$ & $3.64 \pm 1.8$ \\
\hline 356095 & $0.0-0.5$ & $0.049 \pm 0.026$ & $0.211 \pm 0.058$ & -- \\
\hline 356204 & $0.0-0.5$ & -- & $0.226 \pm 0.058$ & $0.053 \pm 0.027$ \\
\hline 356205 & $0.0-0.5$ & $0.117 \pm 0.042$ & $1.38 \pm 0.23$ & $0.173 \pm 0.052$ \\
\hline 356207 & $0.0-0.5$ & $0.469 \pm 0.094$ & $16.5 \pm 2.3$ & $2.23 \pm 0.34$ \\
\hline 356209 & & & & \\
\hline
\end{tabular}

$\mathrm{Am}=$ Americium

bgs $=$ Below ground surface

ID = Identification

$\mathrm{FAL}=$ Final action level

$\mathrm{pCi} / \mathrm{g}=$ Picocuries per gram

$\mathrm{ft}=\mathrm{Foot}$

$\mathrm{Pu}=$ Plutonium

$\mathrm{J}=$ Estimated value

-- = No detects above original action levels

\subsection{Proposed Modification}

Remove the FFACO UR and associated fencing and postings. 


\subsection{CAU 356, CAS 03-09-04 - Mud Pit}

\subsection{CAS Description}

Corrective Action Site 03-09-04 consists of one mud pit that received drill cuttings, drilling fluid, and/or circulated drilling materials during pre-test drilling activities. The mud pit is located west of the potential crater area for U3gi in Area 3 at the NTS. The mud pit is bermed, and tumbleweeds obscure the pit surface. The mud pit is associated with the pre-test drilling activities of either the Tuloso weapons test emplacement hole or the exploratory hole, which were drilled in 1971 and 1972 before the test. Soil originally excavated during construction of the mud pit forms a dirt mound on the southwest margin of the mud pit (NNSA/NV, 2001d).

\subsection{Current Use Restriction Description}

The future use of any land affected by all URs in this CAU is restricted from any DOE or Air Force activity that may alter or modify the containment control, as approved by the state and identified in the CAU CR or other CAU documentation, unless appropriate concurrence is obtained in advance. The UR is defined as the perimeter of the mud pit (approximately 35 by $105 \mathrm{ft}$ ). Three-strand wire fencing approximately $4 \mathrm{ft}$ high was emplaced around the perimeter. Use restriction signs were attached to the top strand of the wire fence on each side of the mud pit. There are no monitoring or inspection requirements associated with this UR (NNSA/NV, 2002a).

\subsection{Basis for Current Use Restriction}

Samples were analyzed for the Streamlined Approach for Environmental Restoration (SAFER) Plan-specified COPCs, which included total VOCs, total SVOCs, total RCRA metals, TPH (DRO and GRO), isotopic U, isotopic Pu, and gamma spectroscopy; and for PCBs, which were not required by the SAFER Plan. Total petroleum hydrocarbons were the only COPC detected above PALs, except for arsenic. Two samples and the field duplicate exceeded the TPH PAL of $100 \mathrm{mg} / \mathrm{kg}$, and TPH was determined to be a COC. The concentration of TPH ranged from 160 to $200 \mathrm{mg} / \mathrm{kg}$. No VOCs or SVOCs were detected above PALs. The concentrations of arsenic above the PAL of $2.7 \mathrm{mg} / \mathrm{kg}$ were within the range considered representative of ambient conditions at the site. Therefore, arsenic is not considered to be a basis for this UR (NNSA/NV, 2002a).

Table 16-1 contains analytical results of all COCs at CAS 03-09-04 that are the basis for the current UR. The sample matrix for all samples is soil. 
Table 16-1

Sample Results for COCs at CAS 03-09-04 Used To Establish Current Use Restriction

\begin{tabular}{||c|c|c|c||}
\hline \multirow{2}{*}{$\begin{array}{c}\text { Sample } \\
\text { ID }\end{array}$} & Sample Location & Depth \\
(ft bgs) & TPH (DRO) & $\begin{array}{c}\text { PAL } \\
\mathbf{1 0 0} \mathbf{~ m g / k g}\end{array}$ \\
\hline \hline 356050 & Point of maximum accumulation & $0.9-1.4$ & 160 \\
\hline 356051 & Surface at point of maximum accumulation & $0.0-0.5$ & 170 \\
\hline 356069 (FD of 356051) & Surface at point of maximum accumulation & $0.0-0.5$ & 200 \\
\hline
\end{tabular}

bgs $=$ Below ground surface

DRO $=$ Diesel-range organics

FD = Field duplicate

$\mathrm{ft}=$ Foot
ID = Identification

$\mathrm{mg} / \mathrm{kg}=$ Milligrams per kilogram

PAL = Preliminary action level

$\mathrm{TPH}=$ Total petroleum hydrocarbons

\subsection{Basis for Use Restriction Modification}

The revised FALs associated with the TPH contamination were established based on the PALs of hazardous constituents of TPH diesel as described in Section 2.2.2. Hazardous constituents of TPH diesel were not detected in any of the samples at concentrations greater than their respective PALs (NNSA/NV, 2002a). Therefore, no contaminants are present at this site in concentrations exceeding the revised FALs, and all revised FALs were established at the PAL concentrations.

\subsection{Proposed Modification}

Remove the FFACO UR and associated fencing and postings from this site. 


\subsection{CAU 358, Areas 18, 19, 20 Cellars/Mud Pits}

\subsection{CAS Descriptions}

Corrective Action Unit 358 has 17 CASs, eight of which have associated URs. Modifications to URs are proposed for the following seven URs at CAU 358 CASs located in Area 20 of the NTS:

- CAS 20-23-02 - Postshot Cellar

- CAS 20-23-03 - Cellar

- CAS 20-23-04 - Postshot Cellar

- CAS 20-23-05 - Postshot Cellar

- CAS 20-23-06 - Cellar

- CAS 20-37-01 - Cellar \& Mud Pit

- CAS 20-37-05 - Cellar

Corrective Action Site 20-23-02 is an open post-test cellar that is $9 \mathrm{ft}$ deep. The cellar floor contains an unknown amount of soil with small amounts of organic material and possible drilling material. A stand pipe protrudes out the top of the cellar. The walls of the cellar are lined with corrugated steel. The cellar is posted as an "Underground Material” (URMA) (NNSA/NSO, 2003h).

Corrective Action Site 20-23-03 is the U-20az open post-test cellar. The cellar floor contains an unknown amount of dark soil with small amounts of organic material and possible drilling material. The walls of the cellar are lined with corrugated steel. The cellar is approximately $12 \mathrm{ft}$ deep and is posted as "Caution Cellar 20az" (NNSA/NSO, 2003h).

Corrective Action Site 20-23-04 is a post-test cellar that was backfilled with soil/gravel. The approximate depth of the cellar is $14.5 \mathrm{ft}$ with a diameter of $9 \mathrm{ft}$. Protruding from the backfill is a metal posting identifying the cellar as "U-20am Postshot" (NNSA/NSO, 2003h).

Corrective Action Site 20-23-05 is located approximately $450 \mathrm{ft}$ southwest of U-20ab. This CAS is a post-test cellar that is open. The cellar floor contains an unknown amount of soil with small amounts of organic material and possible drilling material, and a standpipe protrudes from the top of the cellar. The walls of the cellar are lined with corrugated steel. The cellar is $10 \mathrm{ft}$ deep and is posted as an "URMA" (NNSA/NSO, 2003h).

Corrective Action Site 20-23-06 is located to the west of U-20ac. This post-test cellar is open and is approximately $9 \mathrm{ft}$ deep. The cellar floor contains an unknown amount of soil with small amounts of organic material and possible drilling material. A stand pipe is located within the 
cellar and the walls are lined with corrugated steel. The cellar is posted as an URMA (NNSA/NSO, 2003h).

Corrective Action Site 20-37-01 is located 350 yards northeast of U-20aa. This CAS consists of a post-test cellar approximately $9 \mathrm{ft}$ deep that is open, and a mud pit (approximately 65 by $30 \mathrm{ft}$ ) containing drilling mud and/or drill cuttings. The cellar floor contains an unknown amount of soil with small amounts of organic material and possible drilling material. The walls of the cellar are lined with a square metal casing. Both the cellar and mud pit are posted as an URMA (NNSA/NSO, 2003h). The cellar was listed as an active UGTA monitoring well.

Corrective Action Site 20-37-05 is an open post-test cellar approximately $12 \mathrm{ft}$ deep, and has a stand pipe protruding out the top of the cellar. The cellar floor contains an unknown amount of soil with small amounts of organic material and possible drilling material. The walls of the cellar are lined with corrugated steel. The cellar is posted as an URMA (NNSA/NSO, 2003h).

\subsection{Current Use Restriction Description}

The future use of any land affected by all URs in this CAU is restricted from any DOE or Air Force activity that may alter or modify the containment control, as approved by the state and identified in the CAU CR or other CAU documentation, unless appropriate concurrence is obtained in advance. As part of closure activities, all CAU 358 CASs were backfilled with clean fill and closed in place with a UR. The UR boundaries are defined by the corner points of existing facility demarcation fences or by the cement pad corners. The UR for CAS 20-37-01 applies to the cellar only. There are no site monitoring requirements (NNSA/NSO, 2004b).

\subsection{Basis for Current Use Restriction}

Soil samples were collected and analyzed for VOCs, SVOCs, total RCRA metals, TPH full scan, PCBs, and gamma spectroscopy. Petroleum hydrocarbons (diesel, gasoline, oil, and TPH) were detected above the PAL of $100 \mathrm{mg} / \mathrm{kg}$ in six samples. Petroleum hydrocarbons were the only COPCs detected above action levels; no VOCs or SVOCs were detected above PALs. (NNSA/NSO, 2003h).

Table 17-1 contains analytical results of all COCs at CAU 358 that are the basis for the current URs. The sample matrix for all samples is soil. 
Table 17-1

Sample Results for COCs at CAU 358 Used To Establish Current Use Restriction

\begin{tabular}{||c|c|c|c||}
\hline \multirow{2}{*}{ Sample ID } & Diesel & Oil & TPH \\
\cline { 2 - 4 } & $\begin{array}{c}\text { PAL } \\
\mathbf{1 0 0} \mathbf{~ m g} / \mathbf{k g}\end{array}$ & $\begin{array}{c}\mathbf{P A L} \\
\mathbf{1 0 0} \mathbf{~ m g} / \mathbf{k g}\end{array}$ & $\begin{array}{c}\text { PAL } \\
\mathbf{1 0 0} \mathbf{~ m g} / \mathbf{k g}\end{array}$ \\
\hline \hline $202302-9-C 1$ & 280 & 2,600 & 2,880 \\
\hline $202303-12-C 1$ & 430 & 4,900 & 5,330 \\
\hline $202305-10-C 1$ & 360 & 2,700 & 3,000 \\
\hline $202306-9-C 1$ & -- & 230 & 248 \\
\hline $203701-9-C 1$ & -- & 250 & 290 \\
\hline $203705-12-C 1$ & -- & 3,700 & $3,735.1$ \\
\hline \hline
\end{tabular}

ID = Identification

$\mathrm{mg} / \mathrm{kg}=$ Milligrams per kilogram

$\mathrm{PAL}=$ Preliminary action level

$\mathrm{TPH}=$ Total petroleum hydrocarbons

-- $=$ No detects above action levels

\subsection{Basis for Use Restriction Modification}

The revised FALs associated with the TPH contamination were established based on the PALs of hazardous constituents of TPH diesel as described in Section 2.2.2. Hazardous constituents of TPH diesel were not detected in any of the samples at concentrations greater than their respective PALs (NNSA/NSO, 2003h). Therefore, no contaminants are present at this site in concentrations exceeding the revised FALs, and all revised FALs were established at the PAL concentrations.

\subsection{Proposed Modification}

Remove the FFACO UR and associated fencing and postings from this site. 


\subsection{CAU 394, CAS 12-25-04 - UST 12-16-2 Waste Oil Release}

\subsection{CAS Description}

Corrective Action Site 12-25-04 consists of a documented release of waste oil from underground storage tank (UST) 12-16-2 at Building 12-16. Building 12-16 was used as the light duty shop (or lube shop) for Area 12 from roughly 1965 to the early to mid-1990s when it was closed. Waste oil was accumulated and stored in UST 12-16-2 before disposal. The waste oil release was originally discovered in July 1992, when stained soil was noted in an excavation approximately $10 \mathrm{ft}$ to the south and east of UST 12-16-2. This excavation was intended to be used for the construction of a concrete pad for an AST to replace UST 12-16-2. The stained soil was sampled for a full suite of analysis. Only oil was found to exceed the regulatory limits (100 mg/kg). The release was determined to have exceeded the reporting limits for hydrocarbon spills and was reported to the State of Nevada and assigned the case number H920723D. The UST 12-16-2 was removed from the ground on October 12, 1992 (NNSA/NV, 2001e).

\subsection{Current Use Restriction Description}

The future use of any land affected by this UR is restricted from any DOE or Air Force activity that may alter or modify the containment control, as approved by the state and identified in the CAU CR or other CAU documentation, unless appropriate concurrence is obtained in advance. The UR is for subsurface contamination. Two UR signs, each mounted on a permanent post/pole, were placed around the contamination. There are no monitoring or inspection requirements associated with this UR (NNSA/NSO, 2003d).

\subsection{Basis for Current Use Restriction}

Fourteen soil samples were collected and analyzed for VOCs, SVOCs, RCRA metals, TPH (DRO and GRO), and PCBs. Arsenic and TPH (DRO) were the only contaminants with concentrations exceeding PALs. The concentrations of arsenic were above the PAL but within the range considered representative of ambient conditions at the site; therefore, arsenic is not considered to be a basis for this UR. Total petroleum hydrocarbons concentrations exceeded the PAL of $100 \mathrm{mg} / \mathrm{kg}$ in three samples. No VOCs or SVOCs were detected above PALs (NNSA/NSO, 2003d).

Sampling in the center of the backfilled excavation indicated that there were concentrations of TPH (DRO) that exceeded the PAL at a depth of $6 \mathrm{ft}$ bgs. Samples confirm that the extent of 
contamination does not extend laterally beyond $30 \mathrm{ft}$ north and $35 \mathrm{ft}$ south of the center of the excavation. Contamination does not appear to be present below $20 \mathrm{ft}$ bgs. The source of the release has been removed (NNSA/NSO, 2003d).

Table 18-1 contains analytical results of all COCs at CAS 12-25-04 that are the basis for the current UR. The sample matrix for all samples is soil.

Table 18-1

Sample Results for COCs at CAS 12-25-04

Used To Establish Current Use Restriction

\begin{tabular}{|c|c|c|c||}
\hline \multirow{2}{*}{ Sample ID } & Sample Location & $\begin{array}{c}\text { Depth } \\
\text { (ft bgs) }\end{array}$ & TPH (DRO) \\
\cline { 3 - 4 } & & $\begin{array}{c}\text { PAL } \\
\text { 100 } \mathbf{~ m g / k g}\end{array}$ \\
\hline \hline 394A002 & Borehole 12250401 & $5.5-6$ & $780(\mathrm{~J})$ \\
\hline 394A009 & Borehole 12250403 & $8-8.5$ & 200 \\
\hline 394A010 (FD of 394A009) & Borehole 12250403 & $8-8.5$ \\
\hline $\begin{array}{l}\text { bgs = Below ground surface } \\
\text { FD = Diesel-range organics } \\
\text { J = Estimated duplicate }\end{array}$ & $\begin{array}{l}\text { ft = Foot } \\
\text { ID = Identification } \\
\mathrm{mg} / \mathrm{kg}=\text { Milligrams per kilogram } \\
\text { TPH = Total petroleum hydrocarbons }\end{array}$
\end{tabular}

\subsection{Basis for Use Restriction Modification}

The revised FALs associated with the TPH contamination were established based on the PALs of hazardous constituents of TPH diesel described in Section 2.2.2. Hazardous constituents of TPH diesel were not detected in any of the samples at concentrations greater than their respective PALs (NNSA/NSO, 2003d). Therefore, no contaminants are present at this site in concentrations exceeding the revised FALs, and all revised FALs were established at the PAL concentrations.

\subsection{Proposed Modification}

Remove the FFACO UR and associated fencing and postings from this site. 


\subsection{CAU 394, CAS 18-25-01 - Oil Spills}

\subsection{CAS Description}

Corrective Action Site 18-25-01 consists of spills of oil and fuel (both gasoline and diesel) that were associated with the Area 18 Camp Gas Station. This site was recorded during the original inventory of inactive and abandoned waste sites at the NTS in 1991. The original site inventory form describes the site as "copious oil spills, various sizes, located near and around the old Gas Station 17 Camp” (NNSA/NV, 2001e).

Engineering drawings indicate the service station was in operation by 1964 or 1965 . It is unknown when operations ceased. The USTs for this gas station were originally located southwest of the service station and are not included in the scope of this CAS (NNSA/NV, 2001e).

Surface conditions at the site in 2001 consisted of areas of gravel and weathered asphalt, areas of sediment from a flood event (erosion of the site appeared to be limited), and several concrete pads and the pump islands. It could not be determined during the 2001 site visit whether there is an intact layer of asphalt at the site. Individual stains were not identifiable in available pictures or during site visits (NNSA/NV, 2001e).

\subsection{Current Use Restriction Description}

The future use of any land affected by this UR is restricted from any DOE or Air Force activity that may alter or modify the containment control, as approved by the state and identified in the CAU CR or other CAU documentation, unless appropriate concurrence is obtained in advance. The UR is for subsurface contamination. A single UR sign was mounted on a permanent post/pole and placed at a select location within the CAS. There are no monitoring or inspection requirements associated with this UR (NNSA/NSO, 2003d).

\subsection{Basis for Current Use Restriction}

Twenty-three soil samples were collected from 15 locations and analyzed for VOCs, SVOCs, RCRA metals, TPH (DRO and GRO), PCBs, gamma spectroscopy, isotopic U, and isotopic Pu. Three sample results exceeded the PAL for TPH of $100 \mathrm{mg} / \mathrm{kg}$. Sample 394B004 was collected from the borehole located northwest of the gasoline pump island. Samples 394B006 and 394B007 were collected from the northeast and southeast boreholes of the diesel pump island. All three samples were collected at 3 to $4 \mathrm{ft}$ bgs. Total petroleum hydrocarbons were not 
detected at concentrations exceeding the PAL below $4 \mathrm{ft}$ bgs. Concentrations of TPH (DRO) were not detected in soil samples exceeding the PAL in lateral step-out samples. No VOCs or SVOCs were detected above PALs, and no other COPCs were detected at levels exceeding the PALs (NNSA/NSO, 2003d).

Table 19-1 contains analytical results of all COCs at CAS 18-25-01 that are the basis for the current UR. The sample matrix for all samples is soil.

Table 19-1

Sample Results for COCs at CAS 18-25-01 Used To Establish Current Use Restriction

\begin{tabular}{|c|c|c|c||}
\hline \multirow{2}{*}{ Sample ID } & Sample Location & $\begin{array}{c}\text { Depth } \\
\text { (ft bgs) }\end{array}$ & $\begin{array}{c}\text { TPH (DRO) } \\
\text { 100 } \mathbf{~ m g / k g}\end{array}$ \\
\hline $394 B 004$ & Borehole 18250104 & $3-4$ & 260 \\
\hline $394 B 006$ & Borehole 18250106 & $3-4$ & 110 \\
\hline $394 B 007$ & Borehole 18250107 & $3-4$ & 220 \\
\hline
\end{tabular}

\subsection{Basis for Use Restriction Modification}

The revised FALs associated with the TPH contamination were established based on the PALs of hazardous constituents of TPH diesel as described in Section 2.2.2. Hazardous constituents of TPH diesel were not detected in any of the samples at concentrations greater than their respective PALs (NNSA/NSO, 2003d). Therefore, no contaminants are present at this site in concentrations exceeding the revised FALs, and all revised FALs were established at the PAL concentrations.

\subsection{Proposed Modification}

Remove the FFACO UR and associated fencing and postings from this CAS. 


\subsection{CAU 394, CAS 18-25-02 - Oil Spills, and CAS 18-25-03 - Oil Spill}

\subsection{CAS Descriptions}

Corrective Action Site 18-25-02 consists of contaminated gravel and soil at the location of a former generator shack at the Area 18 Camp. This site was recorded during the original inventory of inactive and abandoned waste sites at the NTS in 1991. The original site inventory form describes the site as "large area of oil spilled on the ground inside the old generator shack (17 Camp).” No engineering drawings or other historical documentation could be found for this building other than those that describe it simply as a generator shack. It appears the shack was in operation by 1964 or 1965, ceased before 1970, and was demolished sometime between 1993 and 1997. The curbing for the foundation is still in place as are several concrete pads within the curbing. The remaining area inside the curbing is filled with pea gravel; some areas of which are darkly stained. It is unknown whether there is a solid concrete foundation under the pea gravel (NNSA/NV, 2001e).

Corrective Action Site 18-25-03 consists of contaminated soil at the former location of an AST. The AST was used to store diesel fuel to run a generator(s) at the Area 18 Control Point. This CAS is located approximately 10 to $20 \mathrm{ft}$ north of CAS 18-25-02. The site is described as "oil spill approximately 6 to $8 \mathrm{ft}^{2}$ located under the aboveground fuel tank, about 300-gallon (gal) capacity, adjacent to the old generator shack." The dates of operation of this tank are assumed to be the same as those of the generator shack. The AST was removed sometime between 1991 and 1997 (NNSA/NV, 2001e).

A PCB- and TPH-contaminated area encompassing both sites was removed and verification samples were collected and analyzed to verify removal of the contamination. Analytical results from the verification samples indicated that PCBs exceeding the PAL were removed, but TPH contamination remained above the PAL. The remaining TPH contamination was closed in place with one UR applying to both CASs 18-25-02 and 18-25-03 (NNSA/NSO, 2003d).

\subsection{Current Use Restriction Description}

The future use of any land affected by this UR is restricted from any DOE or Air Force activity that may alter or modify the containment control, as approved by the state and identified in the CAU CR or other CAU documentation, unless appropriate concurrence is obtained in advance. The UR is for subsurface contamination. Two sides of the combined area are bounded by chain-link fencing. Two UR signs, each mounted on a permanent post/pole, are placed at the 
unfenced sides of the CASs. There are no monitoring or inspection requirements associated with this UR (NNSA/NSO, 2003d).

\subsection{Basis for Current Use Restriction}

Samples from CAS 18-25-02 were analyzed for VOCs, SVOCs, RCRA metals, TPH (DRO and GRO), and PCBs. Samples from CAS 18-25-03 were analyzed for gamma spectroscopy, isotopic U, isotopic Pu, VOCs, SVOCs, RCRA metals, TPH (DRO), and PCBs. Sampling of the material remaining (following remediation) indicated that concentrations of TPH (DRO) exceeded the PAL of $100 \mathrm{mg} / \mathrm{kg}$ at seven locations. On four sides of the excavation, samples were taken at depth to determine whether there has been any lateral migration of TPH (DRO). In addition, a soil boring was advanced in the excavation to determine the depth of contamination of TPH (DRO). The samples at depth and on the four sides of the excavation indicated that the remaining TPH-DRO and -GRO contamination is bounded within the CAS boundaries and by the underlying welded tuff bedrock. No VOCs or SVOCs were detected above PALs. Concentrations of arsenic above the PAL of $2.7 \mathrm{mg} / \mathrm{kg}$ were also found in samples. However, these concentrations are within the range considered representative of ambient conditions at the site. Therefore, arsenic is not considered to be a basis for this UR. Levels of all other contaminants were below the PALs (NNSA/NSO, 2003d).

Table 20-1 contains analytical results of all COCs at CASs 18-25-02 and 18-25-03 that are the basis for the current UR. The sample matrix for all samples is soil.

Table 20-1

Sample Results for COCs at CASs 18-25-02 and 18-25-03 Used To Establish Current Use Restriction

(Page 1 of 2)

\begin{tabular}{|c|c|c|c|c|}
\hline \multirow{2}{*}{$\begin{array}{c}\text { Sample } \\
\text { ID }\end{array}$} & \multirow{2}{*}{ Location/Description } & \multirow{2}{*}{$\begin{array}{l}\text { Depth } \\
\text { (ft bgs) }\end{array}$} & TPH (DRO) & TPH (GRO) \\
\hline & & & $\begin{array}{c}\text { PAL } \\
100 \mathrm{mg} / \mathrm{kg}\end{array}$ & $\begin{array}{c}\text { PAL } \\
100 \mathrm{mg} / \mathrm{kg}\end{array}$ \\
\hline $394 C 085$ & North wall toe of slope & $6-7$ & $4,000(\mathrm{~J})$ & -- \\
\hline 394C091 & West wall toe of slope & $3-4$ & $360(\mathrm{~J})$ & -- \\
\hline $394 C 094$ & South side (surface) & $0-1$ & $390(\mathrm{~J})$ & -- \\
\hline $394 C 095$ & Floor of excavation & $6-7$ & $2,300(\mathrm{~J})$ & -- \\
\hline 394C096 & Floor of excavation & $6-7$ & $1,200(\mathrm{~J})$ & -- \\
\hline $394 C 097$ & Bottom of excavation & $6-7$ & $1,700(\mathrm{~J})$ & -- \\
\hline 394C098 & Floor of excavation & $6-7$ & $450(\mathrm{~J})$ & -- \\
\hline
\end{tabular}


Table 20-1

Sample Results for COCs at CASs 18-25-02 and 18-25-03 Used To Establish Current Use Restriction (Page 2 of 2)

\begin{tabular}{|c|c|c|c|c|}
\hline \multirow{2}{*}{$\begin{array}{l}\text { Sample } \\
\text { ID No. }\end{array}$} & \multirow{2}{*}{ Location/Description } & \multirow{2}{*}{$\begin{array}{l}\text { Depth } \\
\text { (ft bgs) }\end{array}$} & \multirow{2}{*}{$\begin{array}{c}\text { TPH (DRO) } \\
\text { PAL } \\
100 \mathrm{mg} / \mathrm{kg}\end{array}$} & \multirow{2}{*}{$\begin{array}{c}\text { TPH (GRO) } \\
\text { PAL } \\
100 \mathrm{mg} / \mathrm{kg}\end{array}$} \\
\hline & & & & \\
\hline 394C099 & Floor of excavation & $6-7$ & $150(\mathrm{~J})$ & -- \\
\hline $394 C 100$ & Floor of excavation & $6-7$ & $100(\mathrm{~J})$ & -- \\
\hline 394C105 & Deepest point of excavation & $10-12$ & $16,000(\mathrm{~J})$ & -- \\
\hline $394 C 121$ & Boring C09 & $9-10$ & $18,000(\mathrm{~J})$ & 820 \\
\hline \multicolumn{2}{|c|}{$\begin{array}{l}\text { bgs }=\text { Below ground surface } \\
\text { DRO = Diesel-range organics } \\
\mathrm{ft}=\text { Foot } \\
\text { GRO = Gasoline-range organics }\end{array}$} & \multicolumn{3}{|c|}{$\begin{array}{l}\text { ID = Identification } \\
\mathrm{mg} / \mathrm{kg}=\text { Milligrams per kilogram } \\
\mathrm{PAL}=\text { Preliminary action level } \\
\text { TPH = Total petroleum hydrocarbons }\end{array}$} \\
\hline
\end{tabular}

\subsection{Basis for Use Restriction Modification}

The revised FALs associated with the TPH contamination were established based on the PALs of hazardous constituents of TPH diesel as described in Section 2.2.2. Hazardous constituents of $\mathrm{TPH}$ diesel were not detected in any of the samples at concentrations greater than their respective PALs (NNSA/NSO, 2003d). Therefore, no contaminants are present at this site in concentrations exceeding the revised FALs, and all revised FALs were established at the PAL concentrations.

\subsection{Proposed Modification}

Remove the FFACO UR and associated fencing and postings from this CAS. 


\subsection{CAU 394, CAS 29-44-01 - Fuel Spill}

\subsection{CAS Description}

Corrective Action Site 29-44-01 is described as a fuel spill at the Shoshone Transmitter Site in Area 29. No information on the source or exact location of this release was provided.

A historical engineering drawing and a site visit identified two potential release sources at the Shoshone Transmitter Site, a former AST location and a soil stain (NNSA/NV, 2001e).

Historical engineering drawings indicated that there was an AST at the Shoshone Transmitter Station that was removed sometime before 1974. The AST is a potential source of a release. However, several longtime NTS employees at the site did not recall the AST ever having been at the site, or any release at the site. A site visit identified an earthen pad that appears to be in the location where the engineering drawings indicate the AST was located. The earthen pad is approximately $80 \mathrm{ft}$ north of the transmitter station. There was no noted staining or odor evident in the area (NNSA/NV, 2001e).

Site visits to the Shoshone Transmitter Station also identified a hydrocarbon soil stain approximately $4 \mathrm{ft}$ in diameter in the vicinity of the transmitter station. The stain is about $100 \mathrm{ft}$ east of the station and is not related to the former AST location. The stain appears to be of recent origin (i.e., within the last five years) because it was first identified in 1998 and not recorded in previous site visits (NNSA/NV, 2001e).

\subsection{Current Use Restriction Description}

The future use of any land affected by this UR is restricted from any DOE or Air Force activity that may alter or modify the containment control, as approved by the state and identified in the CAU CR or other CAU documentation, unless appropriate concurrence is obtained in advance. The UR is for subsurface contamination. A single UR sign was mounted on a permanent post/pole at each release site. There are no monitoring or inspection requirements associated with this UR (NNSA/NSO, 2003d).

\subsection{Basis for Current Use Restriction}

Samples from the hydrocarbon soil stain were analyzed for VOCs, SVOCs, RCRA metals, TPH (DRO and GRO), and PCBs. Samples from the AST location were analyzed for TPH (DRO). Arsenic and TPH (DRO) were the only COPCs present at the CAS with concentrations exceeding their PALs. One sample from each location had concentrations of 
TPH (DRO) above the PAL of $100 \mathrm{mg} / \mathrm{kg}$. No VOCs or SVOCs were detected above PALs. The concentrations of arsenic above the PAL of $2.7 \mathrm{mg} / \mathrm{kg}$ were within the range considered representative of ambient conditions at the site. Therefore, arsenic is not considered to be a basis for this UR. Results from radiological analyses did not exceed activities greater than, or statistically distinguishable from, background activities (NNSA/NSO, 2003d).

Table 21-1 contains analytical results of all COCs at CAS 29-44-01 that are the basis for the current UR. The sample matrix for all samples is soil.

Table 21-1

Sample Results for COCs at CAS 29-44-01 Used To Establish Current Use Restriction

\begin{tabular}{|c|c|c|c|}
\hline \multirow[b]{2}{*}{ Sample ID } & \multirow[b]{2}{*}{ Sample Location } & \multirow{2}{*}{$\begin{array}{c}\text { Depth } \\
\text { (ft bgs) }\end{array}$} & TPH (DRO) \\
\hline & & & $\begin{array}{c}\mathrm{PAL} \\
100 \mathrm{mg} / \mathrm{kg}\end{array}$ \\
\hline 394F001 & West corner of AST earthen pad & $0-0.5$ & 110 \\
\hline 394F009 & Center of stained soil & $0-0.5$ & $23,000(\mathrm{~J})$ \\
\hline
\end{tabular}

AST = Aboveground storage tank

ID = Identification

bgs = Below ground surface

DRO = Diesel-range organics $\mathrm{mg} / \mathrm{kg}=$ Milligrams per kilogram

$\mathrm{PAL}=$ Preliminary action level

$\mathrm{ft}=$ Foot

$\mathrm{TPH}=$ Total petroleum hydrocarbons

$\mathrm{J}=$ Estimated value

\subsection{Basis for Use Restriction Modification}

The revised FALs associated with the TPH contamination were established based on the PALs of the hazardous constituents of TPH as described in Section 2.2.2. Hazardous constituents of TPH diesel were not detected in the sample with the TPH result of 23,000 mg/kg at concentrations greater than their respective PALs (NNSA/NSO, 2003d). No analytical results of the hazardous constituents of TPH (DRO) were available for the sample with $110 \mathrm{mg} / \mathrm{kg}$ of TPH (DRO). However, it is associated with the same diesel fuel spillage and there is no reasonable expectation that any constituent would exceed PALs. Therefore, no contaminants are present at this site in concentrations exceeding the revised FALs, and all revised FALs were established at the PAL concentrations.

\subsection{Proposed Modification}

Remove the FFACO UR and associated fencing and postings from this CAS. 


\subsection{CAU 398, CAS 25-25-17 - Subsurface Hydraulic Oil Spill}

\subsection{CAS Description}

Corrective Action Site 25-25-17 consists of a hydraulic oil spill identified on December 1, 1998, during the housekeeping closure of CAS 25-25-01 at CAU 297. Because the spill was more extensive than originally believed, CAS 25-25-17 was created. The spill occurred as a result of the continual overfilling of two 10-gal aboveground metal containers, which were used for recirculating oil in a vacuum pump oil recovery system at E-MAD Building 3900 (NNSA/NV, 2001f).

The vacuum oil recovery system was installed in approximately 1965 and operated until the early to mid-1970s. Closure of the vacuum oil recovery system was completed on December 1, 1998. Disposal of the tanks, associated piping, and the first few inches of impacted soil was performed on January 14, 1999. This release was reported to the Nevada Division of Emergency Management on January 21, 1999, as case number NDEM \#99-0120-3281 (NNSA/NV, 2001f).

The spill is in a significant power/utility corridor feeding into Building 3900. The quantity of oil released to the soil was estimated to be greater than 25 gal. While excavating, utilities were identified at a depth of approximately $3 \mathrm{ft}$. Impacted soil was removed to a depth of $18 \mathrm{in}$. Work was discontinued due to the extent of the impacted area, confining work space limitations, and proximity to utilities. Clean soil was used as backfill over the excavated area (NNSA/NV, 2001f).

\subsection{Current Use Restriction Description}

The future use of any land affected by this UR is restricted from any DOE or Air Force activity that may alter or modify the containment control, as approved by the state and identified in the CAU CR or other CAU documentation, unless appropriate concurrence is obtained in advance. The UR states: "Note, the spill site is within the Utility Corridor at E-MAD. Use restrictions apply to the area within the utility corridor.” There are no annual monitoring or inspection requirements (NNSA/NSO, 2003e).

\subsection{Basis for Current Use Restriction}

Samples of the pre-excavation soils at the site were analyzed for TPH (diesel and oil), TCLP VOCs, TCLP SVOCs, TCLP metals, PCBs, pesticides, and gamma spectroscopy. Total petroleum hydrocarbons and PCBs were identified as COCs. Following removal of the 
contaminated soils, TPH (Oil) was the only COC present exceeding the PAL of $100 \mathrm{mg} / \mathrm{kg}$ at concentrations up to $600 \mathrm{mg} / \mathrm{kg}$. No VOCs or SVOCs were detected above PALs. Due to site conditions (e.g., location of utilities, limited space, depth to bedrock, and poor lighting) and limited access, the site was closed in place with a UR (NNSA/NSO, 2003e).

Table 22-1 contains analytical results of all COCs at CAS 25-25-17 that are the basis for the current UR. The sample matrix for all samples is soil.

Table 22-1

Sample Results for COCs at CAS 25-25-17 Used To Establish Current Use Restriction

\begin{tabular}{|c|c|c|}
\hline \multirow[b]{2}{*}{ Sample id } & \multirow{2}{*}{$\begin{array}{l}\text { Depth } \\
\text { (ft bgs) }\end{array}$} & TPH (Oil) \\
\hline & & $\begin{array}{c}\text { PAL } \\
100 \mathrm{mg} / \mathrm{kg}\end{array}$ \\
\hline 252517-1-1 & 1 & 600 \\
\hline $252517-2-1$ & 1 & 530 \\
\hline
\end{tabular}

\subsection{Basis for Use Restriction Modification}

The revised FALs associated with the TPH contamination were established based on the PALs of hazardous constituents of TPH diesel as described in Section 2.2.2. Hazardous constituents of $\mathrm{TPH}$ diesel were not detected in any of the samples at concentrations greater than their respective PALs (NNSA/NSO, 2003e). Therefore, no contaminants are present at this site in concentrations exceeding the revised FALs, and all revised FALs were established at the PAL concentrations.

\subsection{Proposed Modification}

Remove the FFACO UR and associated fencing and postings from this CAS. 


\subsection{CAU 404, CAS TA-03-001-TARC - Roller Coaster Lagoons, and TA-21-001-TARC - Roller Coaster N. Disposal Trench}

\subsection{CAS Descriptions}

The CAU consists of two separate areas: CAS TA-03-001-TARC, Roller Coaster Lagoons, and CAS TA-21-001-TARC, Roller Coaster N. Disposal Trench. Both CASs are co-located approximately $4.3 \mathrm{mi}$ south of Area 3 along the Main Road South on the Tonopah Test Range (TTR). Associated with the CAU is an additional area where a small spill occurred during Voluntary Corrective Action (VCA) activities (DOE/NV, 1996).

The Roller Coaster Lagoons site consists of two large unlined sewage lagoons that received liquid sanitary wastes from the Operation Roller Coaster man camp. The man camp supported up to 600 people for approximately two months in 1963. The sanitary sewer system is approximately 120 by 75 by $10 \mathrm{ft}$. Subsequent to Operation Roller Coaster, the lagoons received debris from construction and range cleanup activities conducted on the TTR (DOE/NV, 1996).

The North Disposal Trench, located north of the eastern-most lagoon, was installed in 1963 to receive solid waste and construction debris from the Operation Roller Coaster man camp. Subsequent to Operation Roller Coaster, the trench continued to receive construction debris and range cleanup debris (including ordnance) from Sandia National Laboratories (SNL) and other operators. The trench is approximately 100 by 12 by $10 \mathrm{ft}$ (DOE/NV, 1996).

A VCA operation removed ordnance and other debris from the two lagoons and trench. The debris and waste was segregated into: (1) recyclable ordnance and debris, (2) nonrecyclable debris, (3) hazardous waste, (4) suspected asbestos-containing materials, and (5) hydrocarbon-contaminated material. All items removed from the lagoons and trench, were screened for radiological contamination with handheld instruments and radiation swipes. No radiological contamination was detected (DOE/NV, 1996).

The North Disposal Trench (CAS TA-21-001-TARC) was clean closed by removal and disposal of the debris and backfilling the pit to grade (DOE/NV, 1998a).

\subsection{Current Use Restriction Description}

The future use of any land affected by this UR is restricted from any DOE or Air Force activity that may alter or modify the containment control, as approved by the state and identified in the 
CAU CR or other CAU documentation, unless appropriate concurrence is obtained in advance. The monitoring will consist of biannual visual inspections of:

- The cover for condition (e.g., subsidence, significant erosion unauthorized excavation) and plant development.

- $\quad$ The fence and signs to determine whether repairs are required.

Nonscheduled inspections may also be required after severe weather events such as heavy rainfall, flash flooding, and high winds. Any identified maintenance and repair requirements will be remedied within 90 days of discovery and documented in writing at the time of repair. Monitoring of the vegetative cover will be conducted during the first, third, and fifth year after revegetation. Monitoring during the first year will determine whether germination of seeded plant species has occurred. By the third year, plant establishment will be evaluated. By the fifth year, long-term survival can be predicted. Concurrently, wildlife use of the site will be evaluated with the objective of determining whether burrowing animals have moved onto the site and to what depth they might be expected to penetrate the cover. The erosion condition of the soil will be evaluated using a qualitative erosion condition classification developed by the Bureau of Land Management. Information gathered will be compared to natural conditions and will be used in assessing whether or not remedial action is necessary so that a viable vegetative cover is established (DOE/NV, 1998a).

It should be noted that the UR description includes a comment that the N. Disposal Trench was clean closed. The N. Disposal Trench is not included in the UR boundary.

\subsection{Basis for Current Use Restriction}

Samples from this CAU were analyzed for VOCs, SVOCs, RCRA metals, TPH, and pesticides. Contaminant levels were below PALs at the N. Disposal Trench CAS; therefore, it is not included in the UR boundary (DOE/NV, 1997). In both the East and West Lagoons, dichlorodiphenyl-dichlorethylene (DDE), dichlorodiphenyl-trichloroethane (DDT), and dichlorodiphenyl-dichloroethane (DDD) concentrations were identified in the surface soil samples above residential PRGs. In the West Lagoon, DDE and DDT concentrations exceeded industrial PRGs.

Table 23-1 contains analytical results of all COCs at CAU 404 that are the basis for the current UR. The sample matrix for all samples is soil. 
Table 23-1

Sample Results for COCs at CAU 404

Used To Establish Current Use Restriction

\begin{tabular}{|c|c|c|c|c|}
\hline \multirow{5}{*}{ Sample ID } & \multirow{5}{*}{ Lagoon } & DDD & DDE & DDT \\
\hline & & \multicolumn{3}{|c|}{ Residential Soil PRGs } \\
\hline & & $1,851 \mu \mathrm{g} / \mathrm{kg}$ & 1,307 $\mu \mathrm{g} / \mathrm{kg}$ & $1,307 \mu \mathrm{g} / \mathrm{kg}$ \\
\hline & & \multicolumn{3}{|c|}{ Industrial Soil PRGs } \\
\hline & & $7,948 \mu \mathrm{g} / \mathrm{kg}$ & $5,610 \mu \mathrm{g} / \mathrm{kg}$ & $5,610 \mu \mathrm{g} / \mathrm{kg}$ \\
\hline TTR00084 & West & -- & 2,200 & 2,500 \\
\hline TTR00087 & West & 3,800 & 3,500 & 9,900 \\
\hline TTR00095 & West & 2,300 & 8,400 & 7,900 \\
\hline TTR00113 & West & 5,400 & 15,000 & 14,000 \\
\hline TTR00076 & East & -- & -- & 1,900 \\
\hline TTR00077 & East & -- & 1,600 & 2,600 \\
\hline \multicolumn{3}{|c|}{$\begin{array}{l}\text { DDD = Dichlorodiphenyl-dichloroethane } \\
\text { DDE = Dichlorodiphenyl-dichlorethylene } \\
\text { DDT = Dichlorodiphenyl-trichloroethane }\end{array}$} & \multicolumn{2}{|c|}{$\begin{array}{l}\text { ID = Identification } \\
\text { PRG = Preliminary remediation goal } \\
\mu \mathrm{g} / \mathrm{kg}=\text { Micrograms per kilogram }\end{array}$} \\
\hline \multicolumn{5}{|c|}{-- = No detects above action levels } \\
\hline
\end{tabular}

\subsection{Basis for Use Restriction Modification}

The revised FALs for DDE, DDT, and DDD as listed in Table 20-2 were established using the Tier 2-based FAL process as presented in Section 2.2.2. These FALs were calculated using the Remote Work Area site-specific exposure scenario. This scenario assumes that a worker will be exposed to the site contaminants for 336 hours per year for 25 years (a total exposure equivalent of 1,050 work days). This exposure scenario is for remote work sites that are not occupied during normal work assignments but where workers may occasionally be sent to perform work (NNSA/NSO, 2006c). Because CAS TA-03-001-TARC, Roller Coaster Lagoons, and CAS TA-21-001-TARC, Roller Coaster N. Disposal Trench, are both located in an inactive area approximately $4.3 \mathrm{mi}$ south of any industrial type sites (Area 3), no current or foreseeable future activities would cause any worker to be exposed to this site for a period of time exceeding that assumed in the remote work area scenario (i.e., 336 hours per year for 25 years).

The UR modification would be to remove CAS TA-21-001-TARC, Roller Coaster N. Disposal Trench, from the UR and to implement an administrative UR for the East and West Lagoons as described in Section 2.0. This administrative UR would restrict any activity that would result in any worker being within the UR boundary for a lifetime-duration of more than 1,050 total workdays. 
Table 23-2 presents the sample results that are the basis for the current UR and demonstrate that none exceed the revised FALs (based on a Remote Work Area land use scenario).

Table 23-2

Revised Final Action Levels for CAU 404

\begin{tabular}{||c|c|c|c|c|}
\hline \multirow{2}{*}{ Sample ID } & \multirow{2}{*}{ Lagoon } & DDD & DDE & DDT \\
\cline { 3 - 5 } & & $\begin{array}{c}\text { Revised FALs } \\
\mathbf{3 3 , 9 0 0} \mathbf{~} \mathbf{g} / \mathbf{k g}\end{array}$ & $\begin{array}{c}\text { Revised FALs } \\
\mathbf{2 3 , 9 0 0} \mathbf{~} \mathbf{g} / \mathbf{k g}\end{array}$ & $\begin{array}{c}\text { Revised FALs } \\
\mathbf{2 1 , 4 0 0} \mathbf{~} \mathbf{g} / \mathbf{k g}\end{array}$ \\
\hline \hline TTR00084 & West & -- & 2,200 & 2,500 \\
\hline TTR00087 & West & 3,800 & 3,500 & 9,900 \\
\hline TTR00095 & West & 2,300 & 8,400 & 7,900 \\
\hline TTR00113 & West & 5,400 & 15,000 & 14,000 \\
\hline TTR00076 & East & -- & -- & 1,900 \\
\hline TTR00077 & East & -- & 1,600 & 2,600 \\
\hline
\end{tabular}

DDD = Dichlorodiphenyl-dichloroethane

ID = Identification

DDE = Dichlorodiphenyl-dichlorethylene

$\mathrm{FAL}=$ Final action level

DDT = Dichlorodiphenyl-trichloroethane

$\mu \mathrm{g} / \mathrm{kg}=$ Micrograms per kilogram

$--=$ No detects above original action levels

\subsection{Proposed Modification}

Implement an administrative UR for the East and West Lagoons as described in Section 2.0 restricting any activity that would result in any worker being within the UR boundary for a lifetime-duration of more than 1,050 total work days. Remove all fencing and postings as well as inspection and maintenance requirements. Remove the N. Disposal Trench from any UR because it was clean closed and contaminant levels were below PALs. 


\subsection{CAU 423, CAS 03-02-002-0308 - Underground Discharge Point}

\subsection{CAS Description}

Corrective Action Unit 423 consists of one CAS located in Area 3 at the TTR. Corrective Action Site 03-02-002-0308 consists of the Underground Discharge Point (UDP) and its associated discharge pipeline extending from Building 03-60, the Auto Maintenance Shop. From approximately 1965 to 1990, the gravity-fed discharge pipeline carried waste oil and other shop products to the UDP. The UDP is $240 \mathrm{ft}$ northwest of the northwest corner of Building 03-60 and is adjacent to a barbed-wire fence near the southwest corner of the Area 3 Boxcar Storage Yard. The UDP consists of a 3.5-ft diameter corrugated metal culvert pipe, which is set vertically in the ground at a depth of $1.5 \mathrm{ft}$ bgs (DOE/NV, 1999a).

\subsection{Current Use Restriction Description}

The future use of any land affected by this UR is restricted from any DOE or Air Force activity that may alter or modify the containment control, as approved by the state and identified in the CAU CR or other CAU documentation, unless appropriate concurrence is obtained in advance. An asymmetrical petroleum hydrocarbon plume, measuring $35 \mathrm{ft}$ in length, $20 \mathrm{ft}$ in width, and 14 to $65 \mathrm{ft}$ in depth, has formed beneath the UDP and migrated westward. A UR was implemented restricting excavation of the area, including the removal of Building 03-60, or excavation of areas impacted by the UDP petroleum hydrocarbon plume, including the discharge pipe leading from Building 03-60. Post-closure monitoring is required and consists of biannual inspections and an annual report containing the inspection checklists (DOE/NV, 1999a).

\subsection{Basis for Current Use Restriction}

A total of 38 soil samples were collected and submitted for laboratory analysis. Samples were analyzed for total VOCs, total SVOCs, total PCBs, total RCRA metals, and TPH (diesel and gasoline). A plume of TPH greater than the PAL of $100 \mathrm{mg} / \mathrm{kg}$ was identified with a maximum dimension of 6 by $11 \mathrm{~m}$ and ranges in depth from a minimum of 4 to $20 \mathrm{~m}$. The plume is asymmetric and primarily west of and below the UDP. With the exception of arsenic, the PALs were not exceeded for total VOCs, total SVOCs, total PCBs, and total RCRA metals for any of the samples collected from the subsurface at the Building 03-60 UDP site. The concentrations of arsenic above the PAL of $2.7 \mathrm{mg} / \mathrm{kg}$ were within the range considered representative of ambient conditions at the site. Therefore, arsenic is not considered to be a basis for this UR. 
Radiological field screening did not detect radiation that was distinguishable from background activities (DOE/NV, 1998b).

Table 24-1 contains analytical results of all COCs at CAS 03-02-002-0308 that are the basis for the current UR. The sample matrix for all samples is soil.

Table 24-1

Sample Results for COCs at CAS 03-02-002-0308 Used To Establish Current Use Restriction

\begin{tabular}{|c|c|c|c|c|}
\hline \multirow{2}{*}{ Borehole No. } & Sample ID & $\begin{array}{c}\text { Sample Depth } \\
\text { (ft bgs) }\end{array}$ & TPH (DRO) & TPH (GRO) \\
\cline { 4 - 5 } & & & $\begin{array}{c}\mathbf{P A L} \\
\mathbf{1 0 0} \mathbf{~} \mathbf{g} / \mathbf{k g}\end{array}$ & $\begin{array}{c}\mathbf{P A L} \\
\mathbf{1 0 0} \mathbf{~} \mathbf{g} / \mathbf{k g}\end{array}$ \\
\hline \hline B1 & TTR01103 & 30 & 2,000 & 560 \\
\hline B1 & TTR01104 & 45 & 1,700 & 430 \\
\hline B6 & TTR01131 & 20 & 2,400 & 640 \\
\hline B6 & TTR01132 & 30 & 1,400 & 550 \\
\hline B6 & TTR01133 & 45 & 1,400 & 670 \\
\hline B6 & TTR01134 & 60 & 1,800 & $760(\mathrm{~J})$ \\
\hline B6 & TTR01137 & 90 & -- & 1,400 \\
\hline B8 & TTR01147 & 35 & 110 & -- \\
\hline B8 & TTR01149 & 60 & 520 & -- \\
\hline \hline
\end{tabular}

bgs = Below ground surface

$\mathrm{DRO}=$ Diesel-range organics

$\mathrm{ft}=$ Foot

ID = Identification

$\mathrm{mg} / \mathrm{kg}=$ Milligrams per kilogram

$\mathrm{PAL}=$ Preliminary action level

$\mathrm{GRO}=$ Gasoline-range organics

$\mathrm{TPH}=$ Total petroleum hydrocarbons

$\mathrm{J}=$ Estimated value

$--=$ No detects above action levels

\subsection{Basis for Use Restriction Modification}

The UR included both the UDP and the associated piping based on the characterization sample results from the UDP. Because piping discharged directly into the UDP, it is reasonable to assume that even if there was any leakage from the piping, contaminants concentrations from any potential piping leak would not exceed concentrations found in the UDP. The samples with the maximum concentrations of TPH from the UDP have no TPH-related contaminant concentrations above their corresponding PALs.

The revised FALs associated with the TPH contamination were established based on the PALs of hazardous constituents of TPH diesel as described in Section 2.2.2. Hazardous constituents of $\mathrm{TPH}$ diesel were not detected in any of the samples at concentrations greater than their respective 
PALs (DOE/NV, 1998b). Therefore, no contaminants are present at this site in concentrations exceeding the revised FALs, and all revised FALs were established at the PAL concentrations.

\subsection{Proposed Modification}

Remove the FFACO UR, associated fencing and postings, and monitoring requirements from this site. 


\subsection{CAU 427, Area 3 Septic Waste Systems 2, 6 (TTR)}

\subsection{CAS Descriptions}

Corrective Action Unit 427 is comprised of the following two CASs located in Area 3 of the TTR:

- CAS 03-05-002-SW02, Septic Waste System

- CAS 03-05-002-SW06, Septic Waste System

The septic waste systems (located within the southwest portion of the Area 3 Compound) were installed to receive sanitary and industrial liquid wastes generated from site maintenance and other daily operations conducted at the Area 3 Compound. Corrective Action Site 03-05-002SW02 and CAS 03-05-002-SW06 will be referred to as Septic Waste System (SWS) 2 and 6 respectively. Septic Waste System 2 and 6 were in operation during different time intervals from 1960 through 1990. Process knowledge of early septic operations regarding disposal practices and composition of waste streams is limited (DOE/NV, 1998c).

The components associated with SWS 2 are the distal end of 1965-1975 leachfield; southern leg of post-1975 leachfield; outfall ends of tanks 33-6 and 33-12; leach beds and drainage ends of the central and northern legs and the distribution box associated with post-1975 leachfield; fork associated with 1965-1975 leachfield; and outfall end of septic tank 33-4. The 1965-1975 leachfield received liquid wastes from all of the contributing SWS 2 and SWS 6 discharge sources during this time period. The post-1975 leachfield was operational until the SNL-consolidated sewer upgrade effectively eliminated the discrete systems that had been in use in the Area 3 Compound (DOE/NV, 1998c).

The component associated with SWS 6 is the pre-1965 leachfield. This is the earliest of the three leachfields at CAU 427 and was installed with the apparent intent to receive liquid wastes from Building 03-60 from 1960 through 1965. A video survey of the active line from Building 03-60 showed no tie-ins, off-shoots, or other irregularities (DOE/NV, 1998c).

\subsection{Current Use Restriction Description}

The future use of any land affected by this UR is restricted from any DOE or Air Force activity that may alter or modify the containment control, as approved by the state and identified in the CAU CR or other CAU documentation, unless appropriate concurrence is obtained in advance (DOE/NV, 1999b). 
Subsurface metal plates were placed at the corners of each use restricted area to simplify boundary detection (using a magnetometer or equivalent) while minimizing marker deterioration due to placement in high-traffic areas. The need for unobstructed road access prompted the placement of warning signs in low-traffic areas and subsurface boundary markers (1 ft bgs) in high-traffic areas (DOE/NV, 1999b).

Annual inspections were to be performed for five years after the completion of closure activities, and documented on inspection forms. Site inspections will document indications of subsidence, erosion, and unauthorized use of soil and asphalt covers. Inspections will document the condition of markers and warning signs. Site monitoring will be used to determine whether maintenance, repairs, and/or modifications to UR administrative controls are needed and/or if termination of post-closure inspections can be proposed (DOE/NV, 1999b). Although no longer required, annual monitoring is still conducted at the site as a BMP (Murphy, 2006).

\subsection{Basis for Current Use Restriction}

Samples collected from the Area 3 SWS 2 and 6 were submitted for total VOCs, total SVOCs, TPH (gasoline and diesel/waste oil), total RCRA metals, total PCBs, and gamma spectroscopy analyses. Results from these analyses identified TPH (waste oil) and arsenic as the only contaminants exceeding PALs. The concentrations of arsenic above the PAL of $2.7 \mathrm{mg} / \mathrm{kg}$ were within the range considered representative of ambient conditions at the site. Therefore, arsenic is not considered to be a basis for this UR. Radiological results from the samples collected from SWS 2 and 6 locations did not exceed PALs (radiation distinguishable from background activities). Of 120 samples, 15 contained TPH as waste oil at concentrations above the PAL of $100 \mathrm{mg} / \mathrm{kg}$. These concentrations are associated with the northern and central distribution lines and the distribution box of the post-1975 leachfield, the proximal end of the 1965-1975 leachfield, and the outfall end of septic tank 33-4. Total petroleum hydrocarbons concentrations above the PAL of $100 \mathrm{mg} / \mathrm{kg}$ are limited laterally to the confines of the two discovered leach systems and have exhibited a low degree of vertical migration, with very few elevated levels, at depths up to $27.5 \mathrm{ft}$ bgs. No VOCs or SVOCs were detected above PALs (DOE/NV, 1998c).

Table 25-1 contains analytical results of all COCs at CAU 427 that are the basis for the current UR. The sample matrix for all samples is soil. 
Table 25-1

Sample Results for COCs at CAU 427

Used To Establish Current Use Restriction

\begin{tabular}{|c|c|c|c|}
\hline \multirow{2}{*}{$\begin{array}{c}\text { Sample } \\
\text { Location/Borehole }\end{array}$} & \multirow[b]{2}{*}{ Sample ID } & \multirow{2}{*}{$\begin{array}{l}\text { Sample Depth } \\
\text { (ft bgs) }\end{array}$} & Waste Oil \\
\hline & & & $\begin{array}{c}\text { PAL } \\
100 \mathrm{mg} / \mathrm{kg}\end{array}$ \\
\hline LF1-T1 & TTR00867 & 4.6 & 120 \\
\hline \multirow{3}{*}{$\begin{array}{l}\text { LF2-T1 \& LF2-T1- } \\
\text { Cutback }\end{array}$} & TTR00871 & 5.5 & 2,400 \\
\hline & TTR00874 & 6.0 & 1,600 \\
\hline & TTR00878 & 10.0 & 680 \\
\hline LF3-T1 & TTR00885 & 5.5 & 370 \\
\hline \multirow{2}{*}{ LF4-T1 } & TTR00887 & 6.0 & 230 \\
\hline & TTR00898 & 7.0 & 1,500 \\
\hline Tank 33-4 & TTR00929 & 5.0 & 2,900 \\
\hline Tank 33-4-SB & TTR00945 & 10.0 & 1,300 \\
\hline LF4-DBOX-SB & TTR00966 & 7.5 & 560 \\
\hline LF4-T1-20.0SEEP-SB & TTR00975 & 10.0 & 140 \\
\hline \multirow{3}{*}{$\begin{array}{c}\text { LF4-T1- } \\
\text { 40.0SEEP(U/G)-SB }\end{array}$} & TTR00990 & 12.5 & 180 \\
\hline & TTR00991 & 17.5 & 330 \\
\hline & TTR00993 & 27.5 & 1,100 \\
\hline Tank 33-5 & $\begin{array}{l}\text { TTR0931, } \\
\text { TTR0933 }\end{array}$ & 7.4 & 610 \\
\hline
\end{tabular}

bgs = Below ground surface

$\mathrm{ft}=$ Foot

$\mathrm{mg} / \mathrm{kg}=$ Milligrams per kilogram

ID = Identification

$\mathrm{PAL}=$ Preliminary action level

\subsection{Basis for Use Restriction Modification}

The revised FALs associated with the TPH contamination were established based on the PALs of hazardous constituents of TPH diesel as described in Section 2.2.2. Hazardous constituents of TPH diesel were not detected in any of the samples at concentrations greater than their respective PALs (DOE/NV, 1998c). Therefore, no contaminants are present at this site in concentrations exceeding the revised FALs, and all revised FALs were established at the PAL concentrations.

\subsection{Proposed Modification}

Remove the FFACO UR, associated fencing and postings, and inspection and maintenance requirements from this site. 


\subsection{CAU 429, CAS 03-51-001-0355 - Photo Shop UDP, Drains}

\subsection{CAS Description}

Process knowledge indicates that potentially contaminated effluent was discharged to UDPs at CAU 429 from various operations at the TTR. The UDPs are subgrade shallow dry wells or excavations filled with gravel. Effluent was discharged to the UDPs through drainage pipes and allowed to percolate into the surrounding soil. Soils surrounding UDPs have likely been impacted by wastewater containing chemicals associated with maintenance (e.g., hydrocarbons or solvents) and/or photo-processing operations (e.g., silver) (DOE/NV, 2000b).

The Area 3 Photoshop (Building 03-55) UDPs were located in the southeast corner of the Area 3 compound. The configuration of each UDP varied. The primary UDP (B1-0355) consisted of a 3-ft-diameter, corrugated steel lining with an overflow pipe located approximately $1.5 \mathrm{ft}$ bgs. The secondary UDP (B2-0355) had a void space to $8 \mathrm{ft}$ bgs, which was backfilled before drilling. The actual depth of the steel lining for both UDPs was not confirmed. The original discharge pipe from Building 03-55 to the primary UDP was rerouted $15 \mathrm{ft}$ south of Building 03-55. The remaining length of pipe appears to be intact and was identified as 4-in. diameter transite pipe located approximately $3 \mathrm{ft}$ bgs (DOE/NV, 2000b).

\subsection{Current Use Restriction Description}

The future use of any land affected by this UR is restricted from any DOE or Air Force activity that may alter or modify the containment control, as approved by the state and identified in the CAU CR or other CAU documentation, unless appropriate concurrence is obtained in advance. There are no site monitoring requirements. The CAS 03-51-001-0355 UR is for future utilization for residential purposes. There are no restrictions for future industrial activities (e.g., excavation for utility installation or maintenance) at the site (DOE/NV, 2000b).

\subsection{Basis for Current Use Restriction}

Samples were analyzed for total VOCs, total SVOCs, and total RCRA metals. In addition, select samples were analyzed for TCLP-silver and isotopic U. All concentrations of VOCs and SVOCs in soil samples were below the PALs at both CASs. All concentrations of total RCRA metals in soil samples were below PALs established in the CAIP (DOE/NV, 1999d) except for arsenic. Although the concentrations of arsenic exceeded the PAL of $3.0 \mathrm{mg} / \mathrm{kg}$, the concentrations are considered representative of ambient conditions for the TTR. Therefore, arsenic is not 
considered to be a basis for this UR. Radiological results for soil samples are not considered to be statistically different from their respective established background levels and, therefore, are below PALs.

Although all results were less than their respective PALs, it was requested that a UR be put in place because the silver concentration exceeded residential PRGs (based on a silver concentration of 2,900 ppm at 27 to $28 \mathrm{ft}$ bgs exceeding the residential PRG of $390 \mathrm{mg} / \mathrm{kg}$ ) (DOE/NV, 2000b).

\subsection{Basis for Use Restriction Modification}

As current action levels are based on industrial PALs, described in Section 2.2, all silver results from this CAS are below the revised PAL of 9,400 mg/kg (DOE/NV, 2000b). Therefore, no contaminants are present at this site in concentrations exceeding PALs, and the revised FALs were established at the PAL concentrations.

\subsection{Proposed Modification}

Remove the FFACO UR and associated fencing and postings from this site. 


\subsection{CAU 454, CAS 12-25-09, Spill 960722-02 (from UST 12-B-3)}

\subsection{CAS Description}

The UST 12-B-3 was located west of the main portal entrance to B-Tunnel. The tank was located on top of an abandoned bunker facility constructed into the mountainside. The tank had an approximate capacity of 1,900 liters (500 gal), was empty at the time of identification, and was removed on May 6, 1996. One sample collected from below the tank bottom during excavation had a TPH concentration of $310 \mathrm{mg} / \mathrm{kg}$, as waste oil; but upon exposing the tank, it was discovered that it was constructed of galvanized steel and was most likely used to store water. In addition, the tank interior was observed to be clean and had no evidence of being used to store fuel or oil. Further investigation of the site suggested that, because the tank was located on top of a bunker complex, the source of the oil hydrocarbons may be from an oil sealant of the structure exterior or from wooden supports identified in the excavation bottom (DOE/NV, 1998d).

\subsection{Current Use Restriction Description}

The future use of any land affected by this UR is restricted from any DOE or Air Force activity that may alter or modify the containment control, as approved by the state and identified in the CAU CR or other CAU documentation, unless appropriate concurrence is obtained in advance. There are no site monitoring requirements (Lawrence, 2000). There is a larger UR (for CASs 12-01-09, 12-06-05, 12-06-07, and 12-06-08) that encompasses this UR.

\subsection{Basis for Current Use Restriction}

Five soil samples were taken from the site and analyzed for TPH (oil). The current UR is based on one sample with a TPH (oil) concentration of $120 \mathrm{mg} / \mathrm{kg}$, exceeding the $100 \mathrm{mg} / \mathrm{kg}$ PAL (DOE/NV, 1998d).

\subsection{Basis for Use Restriction Modification}

Upon removal of this UR, the larger UR (for CASs 12-01-09, 12-06-05, 12-06-07, and 12-06-08) that encompasses this UR, will remain in place and will prevent inadvertent entry into the area covered by this UR.

\subsection{Proposed Modification}

Remove the FFACO UR from this site, but leave the larger UR (for CASs 12-01-09, 12-06-05, 12-06-07, and 12-06-08) that encompasses the FFACO UR. 


\subsection{References}

ASTM, see American Society for Testing and Materials.

American Society for Testing and Materials. 1995. Standard Guide for Risk-Based Corrective Action Applied at Petroleum Release Sites, ASTM E 1739-95 (Reapproved 2002). Philadelphia, PA.

BYU, see Brigham Young University.

Brigham Young University. 1999. Groundwater Modeling System Reference Manual, Version 3. Provo, UT.

DOE, see U.S. Department of Energy.

DOE/NV, see U.S. Department of Energy, Nevada Operations Office.

EPA, see U.S. Environmental Protection Agency.

Elle, D.R., Nevada Division of Environmental Protection. 2006. Letter to J. Appenzeller-Wing (NNSA/NSO) entitled, "Acceptance of the Post Closure Inspection and Monitoring Report Corrective Action Unit (CAU) 342: Mercury Fire Training Pit Calendar Years 2004-2005, Nevada Test Site, Nevada, Federal Facility Agreement and Consent Order," 28 August. Las Vegas, NV.

FFACO, see Federal Facility Agreement and Consent Order.

Federal Facility Agreement and Consent Order. 1996 (as amended). Agreed to by the State of Nevada; U.S. Department of Energy, Environmental Management; U.S. Department of Defense; and U.S. Department of Energy, Legacy Management.

Lawrence, S.J., U.S. Department of Energy, Nevada Operations Office. 2000. Letter to R.C. Wycoff, (DOE/NV) entitled, "Completion of Information into FIMS on CAU Numbers 424, 427, 40, 44, 339, 364, 452, 454, 456, and 464 by Bechtel Nevada (BN),” 24 January. Las Vegas, NV.

Moore, J., Science Applications International Corporation. 1999. Memorandum to M. Todd (SAIC) entitled, "Background Concentrations for NTS and TTR Soil Samples," 3 February. Las Vegas, NV: IT Corporation.

Murphy, T., Bureau of Federal Facilities. 2004. Letter to R. Bangerter (NNSA/NSO) entitled, "Review of Industrial Sites Project Document Guidance for Calculating Industrial Sites Project Remediation Goals for Radionuclides in Soil Using the Residual Radiation (RESRAD) Computer Code," 19 November. Las Vegas, NV. 
Murphy, T.H., Nevada Division of Environmental Protection. 2006. Letter to J.B. Jones, (DOE/NV) entitled, "NNSA/NSO Request to Reduce the Frequency of Post-Closure Monitoring of Corrective Action Units (CAU) 400, 404, 407, 423, 424, 426, 427, 453, and 487 at Tonopah Test Range (TTR), Nevada,” 5 December. Las Vegas, NV.

NAC, see Nevada Administrative Code.

NBMG, see Nevada Bureau of Mines and Geology.

NCRP, see National Council on Radiation Protection and Measurements.

NNSA/NSO, see U.S. Department of Energy, National Nuclear Security Administration Nevada Site Office.

NNSA/NV, see U.S. Department of Energy, National Nuclear Security Administration Nevada Operations Office.

National Council on Radiation Protection and Measurements. 1999. Recommended Screening Limits for Contaminated Surface Soil and Review of Factors Relevant to Site-Specific Studies, NCRP Report No. 129. Bethesda, MD.

Nevada Administrative Code. 2006a. NAC 445A.227, “Contamination of Soil: Order by Director for Corrective Action; Factors To Be Considered in Determining Whether Corrective Action Required." Carson City, NV. As accessed at http://www.leg.state.nv.us/nac on 13 December, 2007.

Nevada Administrative Code. 2006b. NAC 445A.22705, "Contamination of Soil: Evaluation of Site by Owner or Operator; Review of Evaluation by Division.” Carson City, NV. As accessed at http://www.leg.state.nv.us/nac.

Nevada Administrative Code. 2006c. NAC 445A.2272, “Contamination of Soil: Establishment of Action Levels.” Carson City, NV. As accessed at http://www.leg.state.nv.us/nac on December 132007.

Nevada Bureau of Mines and Geology. 1998. Mineral and Energy Resource Assessment of the Nellis Air Force Range, Open-File Report 98-1. Reno, NV.

U.S. Department of Energy. 1993. Radiation Protection of the Public and the Environment, DOE Order 5400.5, Change 2. Washington, DC.

U.S. Department of Energy, National Nuclear Security Administration Nevada Operations Office. 2001a. Corrective Action Decision Document for Corrective Action Unit 262: Area 25 Septic Systems and Underground Discharge Point, Nevada Test Site, Nevada, Rev. 1, DOE/NV--744-Rev 1. September. Las Vegas, NV 
U.S. Department of Energy, National Nuclear Security Administration Nevada Operations Office. 2001b. Corrective Action Decision Document/Closure Report for Corrective Action Unit 321: Area 22 Weather Station Fuel Storage, Nevada Test Site, Nevada, Rev. 1, DOE/NV--726. August. Las Vegas, NV.

U.S. Department of Energy, National Nuclear Security Administration Nevada Operations Office. 2001c. Corrective Action Decision Document for Corrective Action Unit 335: Area 6 Injection Well and Drain Pit, Nevada Test Site, Nevada, Rev. 0, DOE/NV--759. November. Las Vegas, NV.

U.S. Department of Energy, National Nuclear Security Administration Nevada Operations Office. 2001d. Streamlined Approach for Environmental Restoration (SAFER) Plan for Corrective Action Unit 356: Mud Pits and Disposal Sites, Nevada Test Site, Nevada, Rev. 0, DOE/NV--747. August. Las Vegas, NV.

U.S. Department of Energy, National Nuclear Security Administration Nevada Operations Office. 2001e. Streamlined Approach for Environmental Restoration (SAFER) Plan for Corrective Action Unit 394: Areas 12, 18, and 29 Spill/Release Sites, Nevada Test Site, Nevada, Rev. 0, DOE/NV--755. September. Las Vegas, NV.

U.S. Department of Energy, National Nuclear Security Administration Nevada Operations Office. 2001f. Streamlined Approach for Environmental Restoration (SAFER) Plan for Corrective Action Unit 398: Area 25 Spill Sites, Nevada Test Site, Nevada, Rev. 0, DOE/NV--785. November. Las Vegas, NV.

U.S. Department of Energy, National Nuclear Security Administration Nevada Operations Office. 2002a. Closure Report for Corrective Action Unit 356: Mud Pits and Disposal Sites, Nevada Test Site, Nevada, Rev. 1, DOE/NV--835-REV.1. November. Las Vegas, NV.

U.S. Department of Energy, National Nuclear Security Administration Nevada Operations Office. 2002b. Corrective Action Decision Document/Closure Report for Corrective Action Unit 34: Area 3 Contaminated Waste Sites, Nevada Test Site, Nevada, Rev. 0, DOE/NV--811. April. Las Vegas, NV.

U.S. Department of Energy, National Nuclear Security Administration Nevada Operations Office. 2002c. Underground Test Area Project Waste Management Plan, DOE/NV--343-Rev. 2. Las Vegas, NV.

U.S. Department of Energy, National Nuclear Security Administration Nevada Site Office. 2003a. Closure Report for Corrective Action Unit 262: Area 25 Septic Systems and Underground Discharge Point, Nevada Test Site, Nevada, Rev. 1, DOE/NV--897-Rev 1. July. Las Vegas, NV. 
U.S. Department of Energy, National Nuclear Security Administration Nevada Site Office. 2003b. Closure Report for Corrective Action Unit 335: Area 6 Injection Well and Drain Pit, Nevada Test Site, Nevada, Rev. 0, DOE/NV--910. June. Las Vegas, NV.

U.S. Department of Energy, National Nuclear Security Administration Nevada Site Office. 2003c. Closure Report for Corrective Action Unit 355: Area 2 Cellars/Mud Pits, Nevada Test Site, Nevada, Rev. 0, DOE/NV--934. November. Las Vegas, NV.

U.S. Department of Energy, National Nuclear Security Administration Nevada Site Office. 2003d. Closure Report for Corrective Action Unit 394: Areas 12, 18, and 29 Spill/Release Sites, Nevada Test Site, Nevada, Rev. 0, DOE/NV--931. September. Las Vegas, NV.

U.S. Department of Energy, National Nuclear Security Administration Nevada Site Office. 2003e. Closure Report for Corrective Action Unit 398: Area 25 Spill Sites, Nevada Test Site, Nevada, Rev. 1, DOE/NV--873 REV 1. April. Las Vegas, NV.

U.S. Department of Energy, National Nuclear Security Administration Nevada Site Office. 2003f. Corrective Action Investigation Plan for Corrective Action Unit 322: Areas 1 and 3 Release Sites and Injection Wells, Nevada Test Site, Nevada, Rev. 0, DOE/NV--901. July. Las Vegas, NV.

U.S. Department of Energy, National Nuclear Security Administration Nevada Site Office. 2003g. Streamlined Approach for Environmental Restoration Plan for Corrective Action Unit 355: Area 2 Cellars and Mud Pits, Nevada Test Site, Nevada, Rev. 1, DOE/NV--868-REV 1. Las Vegas, NV.

U.S. Department of Energy, National Nuclear Security Administration Nevada Site Office. 2003h. Streamlined Approach for Environmental Restoration Plan for Corrective Action Unit 358: Areas 18, 19, 20 Cellars/Mud Pits, Nevada Test Site, Nevada, Rev. 1, DOE/NV--837-REV 1. February. Las Vegas, NV.

U.S. Department of Energy, National Nuclear Security Administration Nevada Site Office. 2004a. Closure Report for Corrective Action Unit 271: Areas 25, 26, and 27 Septic Systems, Nevada Test Site, Nevada, Rev. 0, DOE/NV--998. August. Las Vegas, NV.

U.S. Department of Energy, National Nuclear Security Administration Nevada Site Office. 2004b. Closure Report for Corrective Action Unit 358: Areas 18, 19, 20 Cellars/Mud Pits, Nevada Test Site, Nevada, Rev 0, DOE/NV--944. January. Las Vegas, NV.

U.S. Department of Energy, National Nuclear Security Administration Nevada Site Office. 2004c. Corrective Action Decision Document for Corrective Action Unit 214: Bunkers and Storage Areas Nevada Test Site, Nevada, Rev. 0, DOE/NV--956. August. Las Vegas, NV. 
U.S. Department of Energy, National Nuclear Security Administration Nevada Site Office. 2004d. Corrective Action Decision Document for Corrective Action Unit 271: Areas 25, 26, and 27 Septic Systems, Nevada Test Site, Nevada, Rev. 1, DOE/NV--838-REV.1. September. Las Vegas, NV.

U.S. Department of Energy, National Nuclear Security Administration Nevada Site Office. 2004e. Corrective Action Decision Document for Corrective Action Unit 322: Areas 1 and 3 Release Sites and Injection Wells Nevada Test Site, Nevada, Rev. 0, DOE/NV--1023. December. Las Vegas, NV.

U.S. Department of Energy, National Nuclear Security Administration Nevada Site Office. 2004f. NV/YMP Radiological Control Manual, DOE/NV--11718-079, Rev. 5. Prepared by Bechtel Nevada. Las Vegas, NV.

U.S. Department of Energy, National Nuclear Security Administration Nevada Site Office. 2006a. Closure Report for Corrective Action Unit 214: Bunkers and Storage Areas, Nevada Test Site, Nevada, Rev. 0, DOE/NV-1160. September. Las Vegas, NV.

U.S. Department of Energy, National Nuclear Security Administration Nevada Site Office. 2006b. Closure Report for Corrective Action Unit 322: Areas 1 and 3 Release Sites and Injection Wells, Nevada Test Site, Nevada, Rev. 0, DOE/NV--1134. June.

Las Vegas, NV.

U.S. Department of Energy, National Nuclear Security Administration Nevada Site Office. 2006c. Industrial Sites Project Establishment of Final Action Levels, Rev. 0, DOE/NV--1107. Las Vegas, NV.

U.S. Department of Energy, National Nuclear Security Administration Nevada Site Office. 2006d. Post-Closure Inspection and Monitoring Report for Corrective Action Unit 342: Area 23 Mercury Fire Training Pit, Nevada Test Site, Nevada, for Calendar Years 2004-2005, Rev. 0, DOE/NV--1151. August. Las Vegas, NV.

U.S. Department of Energy, Nevada Operations Office. 1996. Corrective Action Investigation Plan: Roller Coaster Lagoons and North Disposal Trench, Tonopah Test Range, Nevada, Rev. 0, DOE/NV--425. June. Las Vegas, NV.

U.S. Department of Energy, Nevada Operations Office. 1997. Corrective Action Decision Document for the Roller Coaster Lagoons and North Disposal Trench (Corrective Action Unit No. 404), Rev. 0, DOE/NV--474. March. Las Vegas, NV.

U.S. Department of Energy, Nevada Operations Office. 1998a. Closure Report for Corrective Action Unit 404: Roller Coaster Sewage Lagoons and North Disposal Trench, Tonopah Test Range, Nevada, Rev. 0, DOE/NV/11718-187. September. Las Vegas, NV. 
U.S. Department of Energy, Nevada Operations Office. 1998b. Corrective Action Decision Document for Corrective Action Unit 423: Building 03-60 Underground Discharge Point, Tonopah Test Range, Nevada, Rev. 0, DOE/NV--508, UC-700. June. Las Vegas, NV.

U.S. Department of Energy, Nevada Operations Office. 1998c. Corrective Action Decision Document for Corrective Action Unit 427: Area 3 Septic Waste Systems 2 and 6, Tonopah Test Range, Nevada, Rev 0, DOE/NV--509, UC-700. June. Las Vegas, NV.

U.S. Department of Energy, Nevada Operations Office. 1998d. Streamlined Approach for Environmental Restoration Closure Report for Corrective Action Unit 454 Historical Underground Storage Tank Release Sites, Tank Release Sites, Nevada Test Site, Nevada, Rev. 0, DOE/NV/11718-211. April. Las Vegas, NV.

U.S. Department of Energy, Nevada Operations Office. 1999a. Closure Report for Corrective Action Unit 423: Area 3 Building 03-60 Underground Discharge Point, Tonopah Test Range, Nevada, Rev. 0, DOE/NV--253. July. Las Vegas, NV.

U.S. Department of Energy, Nevada Operations Office. 1999b. Closure Report for Corrective Action Unit 427: Area 3 Septic Waste Systems 2 and 6, Tonopah Test Range, Nevada, DOE/NV--561. August. Las Vegas, NV.

U.S. Department of Energy, Nevada Operations Office. 1999c. Corrective Action Decision Document for Corrective Action Unit 342: Area 23 Mercury Fire Training Pit, Nevada Test Site, Nevada, Rev. 1, DOE/NV--534-REV. 1. June. Las Vegas, NV.

U.S. Department of Energy, Nevada Operations Office. 1999d. Corrective Action Investigation Plan for Corrective Action Unit 406: Area 3 Building 03-74 \& Building 03-58 Underground Discharge Points and Corrective Action Unit 429: Area 3 Building 03-55 \& Area 9 Building 09-52 Underground Discharge Points, Tonopah Test Range, Nevada, Rev. 0, DOE/NV--547. May. Las Vegas, NV.

U.S. Department of Energy, Nevada Operations Office. 2000a. Closure Report for Corrective Action Unit 342: Area 23 Mercury Fire Training Pit, Nevada Test Site, Nevada, Rev. 0, DOE/NV--603. April. Las Vegas, NV.

U.S. Department of Energy, Nevada Operations Office. 2000b. Corrective Action Decision Document/Closure Report for Corrective Action Unit 406: Area 3 Building 03-74 \& Building 03-58 Underground Discharge Points and Corrective Action Unit 429: Area 3 Building 03-55 \& Area 9 Building 09-52 Underground Discharge Points, Tonopah Test Range, Nevada, Rev 0, DOE/NV--591. March. Las Vegas, NV.

U.S. Department of Energy, Nevada Operations Office. 2000c. Corrective Action Investigation Plan for Corrective Action Unit 335: Area 6 Injection Well and Drain Pit, Nevada Test Site, Nevada, Rev. 0, DOE/NV--663. December. Las Vegas, NV. 
U.S. Department of Energy, Nevada Operations Office. 2001a. Corrective Action Investigation Plan for Corrective Action Unit 34: Area 3 Contaminated Waste Sites Nevada Test Site, Nevada, Rev. 0, DOE/NV--701. March. Las Vegas, NV.

U.S. Department of Energy, Nevada Operations Office. 2001b. Corrective Action Investigation Plan for Corrective Action Unit 271: Areas 25, 26, and 27 Septic Systems, Nevada Test Site, Nevada, Rev. 0, DOE/NV--704. April. Las Vegas, NV.

U.S. Environmental Protection Agency. 2004. Region 9 Preliminary Remediation Goals (PRGs). As accessed at http://www.epa.gov/region09/waste/sfund/prg/index.htm. on 13 December, 2007. Prepared by S.J. Smucker. San Francisco, CA. 


\section{Appendix A}

Nevada Division of Environmental Protection Comment Responses

(2 Pages) 


\section{NEVADA ENVIRONMENTAL RESTORATION PROJECT DOCUMENT REVIEW SHEET}

\begin{tabular}{|l|l|}
\hline 1. Document Title/Number: & $\begin{array}{l}\text { Draft Draft Recommendations and Justifications for Modifications for } \\
\text { Use Restrictions Established under the U.S. Department of Energy, } \\
\text { National Nuclear Security Administration, Nevada Site Office, } \\
\text { Federal Facility Agreement and Consent Order, Revision 0, } \\
\text { December 2007 }\end{array}$
\end{tabular}

\begin{tabular}{|l|l|l|l|}
\hline $\begin{array}{l}\text { 10. Comment } \\
\text { Number/Location }\end{array}$ & 11. Type* & 12. Comment & 13. Comment Response \\
\hline 1.) General & Mandatory & $\begin{array}{l}\text { 14. Accept } \\
\text { This report includes mention of only those CASs that } \\
\text { have Use Restrictions. Some of the CAUs involved } \\
\text { have other CASs within their scope that will not be } \\
\text { examined or have their Use Restrictions modified. A } \\
\text { the CASs involved in the study in order to insure that } \\
\text { consistency is maintained, i.e. Why was the level of } \\
\text { contamination left in place? Was there a reason that } \\
\text { might extend to other CASs within the CAU. }\end{array}$ & $\begin{array}{l}\text { Agree. Section 1.0, Purpose, was replaced with the } \\
\text { following text: } \\
\text { "Many Federal Facility Agreement and Consent Order } \\
\text { (FFACO) Use Restrictions (URs) have been } \\
\text { part of FFACO corrective actions (FFACO, 1996; as } \\
\text { amended January 2007). Since the signing of the } \\
\text { FFACO in 1996, practices and procedures relating to } \\
\text { the implementation of risk-based corrective action } \\
\text { (RBCA) have evolved. This document is part of an } \\
\text { effort to re-evaluate all FFACO URs against the current } \\
\text { RBCA criteria (referred to in this document as the } \\
\text { Industrial Sites [IS] RBCA process) as defined in the } \\
\text { Industrial Sites Project Establishment of Final Action } \\
\text { Levels (NNSA/NSO, 2006c). Based on this evaluation, } \\
\text { the URs were sorted into the following categories: }\end{array}$ \\
\hline
\end{tabular}


NEVADA ENVIRONMENTAL RESTORATION PROJECT DOCUMENT REVIEW SHEET

\begin{tabular}{|c|c|c|c|c|}
\hline $\begin{array}{l}\text { 10. Comment } \\
\text { Number/Location }\end{array}$ & 11. Type* & 12. Comment & 13. Comment Response & 14. Accept \\
\hline 1.) (continued) & Mandatory & & $\begin{array}{l}\text { 1.Where sufficient information exists to determine that } \\
\text { the current UR is consistent with the RCBA criteria } \\
\text { 2.Where sufficient information exists to determine that } \\
\text { the current UR may be removed or downgraded based } \\
\text { on RCBA criteria. } \\
\text { 3.Where sufficient information does not exist to } \\
\text { evaluate the current UR against the RCBA criteria. } \\
\text { After reviewing all the existing FFACO URs, the } 49 \\
\text { URs addressed in this document have sufficient } \\
\text { information to determine that these current URs may } \\
\text { be removed or downgraded based on RCBA criteria. } \\
\text { This document presents recommendations on } \\
\text { modifications to existing URs that will be consistent } \\
\text { with the RCBA criteria." } \\
\text { NOTE: This comment was also applied to the } \\
\text { document, Supplemental Investigation Plan for FFACO } \\
\text { Use Restrictions. }\end{array}$ & \\
\hline 2.) General & Mandatory & $\begin{array}{l}\text { In addition, all new sampling must be carried out as } \\
\text { close as possible to the contamination found in the } \\
\text { original investigation. }\end{array}$ & $\begin{array}{l}\text { No new sampling is proposed in this document as } \\
\text { sufficient information is already available to compare to } \\
\text { the RCBA criteria. The stated objective in the SIP } \\
\text { document is that: } \\
\text { "supplemental investigations described are limited to } \\
\text { collecting information about the potentially hazardous } \\
\text { constituents of TPH, from the areas previously defined, } \\
\text { as containing the highest concentration of TPH. Based } \\
\text { on results from previous investigations at these } \\
\text { sites.....Areas with the highest TPH contamination are } \\
\text { well documented and/or biasing factors exist to ensure } \\
\text { sampling is conducted in the areas where maximum } \\
\text { concentrations are expected." }\end{array}$ & \\
\hline
\end{tabular}




\section{Library Distribution List}

\section{$\underline{\text { Copies }}$}

U.S. Department of Energy

1 (Uncontrolled, electronic copy)

National Nuclear Security Administration

Nevada Site Office

Technical Library

P.O. Box 98518, M/S 505

Las Vegas, NV 89193-8518

U.S. Department of Energy

1 (Uncontrolled, electronic copy)

Office of Scientific and Technical Information

P.O. Box 62

Oak Ridge, TN 37831-0062

Southern Nevada Public Reading Facility

2 (Uncontrolled, electronic copies)

c/o Nuclear Testing Archive

P.O. Box 98521, M/S 400

Las Vegas, NV 89193-8521

Manager, Northern Nevada FFACO

1 (Uncontrolled, electronic copy)

Public Reading Facility

c/o Nevada State Library \& Archives

100 N Stewart Street

Carson City, NV 89701-4285 